GRÁCIA LOPES LIMA

\title{
EDUCAÇÃO PELOS MEIOS DE COMUNICAÇÃO: PRODUÇÃO COLETIVA DE COMUNICAÇÃO NA PERSPECTIVA DA EDUCOMUNICAÇÃO
}




\section{GRÁCIA LOPES LIMA}

\section{EDUCAÇÃO PELOS MEIOS DE COMUNICAÇÃO: PRODUÇÃO COLETIVA DE COMUNICAÇÃO NA PERSPECTIVA DA EDUCOMUNICAÇÃO}

Tese apresentada à Faculdade de Educação da Universidade de São Paulo para obtenção do título de Doutor em Educação.

Área de concentração: Cultura, Organização e Educação

Orientador: Prof. Dr. Marcos Ferreira Santos 


\begin{tabular}{ll}
\hline 371.112 & Lima, Grácia Lopes \\
L732e & Educação pelos meios de comunicação: produção coletiva de \\
comunicação, na perspectiva da educomunicação / Grácia Lopes Lima; \\
orientação Marcos Ferreira Santos. São Paulo: s.n., 2009. \\
135 p. ; 2 DVDs \\
Tese (Doutorado - Programa de Pós-Graduação em Educação. Área \\
de Concentração: Cultura, Organização e Educação) - - Faculdade de \\
Educação da Universidade de São Paulo. \\
1. Educação 2. Comunicação 3. Educomunicação I. Santos, Marcos \\
Ferreira, orient.
\end{tabular}




\section{FOLHA DE APROVAÇÃO}

Grácia Lopes Lima

Educação pelos Meios de Comunicação: produção coletiva de comunicação na perspectiva da Educomunicação

Tese apresentada à Faculdade de Educação da Universidade de São Paulo para obtenção do título de Doutor em Educação.

Área de concentração: Cultura, Organização e Educação

Aprovada em

Banca Examinadora

Prof. Dr.

Instituição:

Assinatura

Prof. Dr.

Instituição:

Assinatura

Prof. Dr.

Instituição:

Assinatura

Prof. Dr.

Instituição:

Assinatura

Prof. Dr.

Instituição:

Assinatura 
Para o GENS - Serviços Educacionais
e o
Projeto Cala-boca já morreu 


\section{AGRADECIMENTOS}

Minha mãe, Judith Lopes de Lima, em quem me inspiro, pelo esmero, vigor e capacidade de transformação; meu pai, Air de Lima, por me levar para ver com olhos de menina o centro, os depósitos e os lixos; Donizete Soares, pelas intensas, precisas, constantes e preciosas iniciações, braveza e doçura; Clorinda, Stella D’Alma e Cecília, 1a série azul-marinho, colegiais da noite do Colégio Pe. Moye, pelas primeiras inquietações profissionais; Plínio Marcos, que me pôs na trilha do bando; Mayra Lima Soares, pela harmonia; Isis Lima Soares, pela presença constante, fonte de inspiração, GENS, pelas possibilidades; Ercília Mendonza, pela passagem; Ludmila, pela permissão da escuta, Rádio Cidadã, pelas descobertas; Luci Martins, pela bela parceria, Edson Fragoaz, pelas pedras jogadas em minhas águas, Mayra, Helen, Michel, Arony, Rodrigo, Fábio e André, Kamila, Rodolfo, Ângelo, do Porrada no ar, pelo desafio, Isis, Thiago e Ariane, Maíra e Gibran, Mônica e Renata, Calhandra, Hiléia e Larissa, Mariana Kz e Gabi, Luana e Melina, Hans, Renato, Lígia, Adriano, Cadu, Liz, Mariana Manfredi Magalhães, Ticiane, Felipe, Jefferson, Tiago, Renata, Bruno, Amanda, Gabriel, Sílvia, Lúcia, Laúcia, Ana, Flávio, Fernanda, Mariana Teófilo, Rodrigo, Vagner, Vanessa, Diego, Lincoln, Fred, Fernando, Henrique, César, Maria Paula, Marcela, Jade, Larissa, Larissa Guimarães, Ingrid, Kevin, Sofia, Lívia; Julyana, Maryana, Mylena, Jacqueline, Joyce, do Cala-boca já morreu, um Projeto de Vida, por isso tão inspirador; Antonio Carlos Escudero e Centro Dehoniano de Comunicação, pelas novas parcerias, Samuel Barreto, pelo envolvimento e disponibilidade; Nanato Santos, Carlão, Luís Carlos, Elaine, Israel, do Ondas Paranóicas, pelo equilíbrio; Neide Cândido Brás, fada madrinha do GENS; Rádios comunitárias 8 de dezembro, Charme e Guadalupe, pela constatação de que uma outra comunicação é possível (e necessária); Mariúza Peloso, pelo respeito e carinho; Patrícia Moldan, Cris Lopérgolo, Sérgio D’Urquiza, pelas buscas conjuntas; Prof. Ismar de Oliveira Soares, pelo aprendizado; Patrícia Horta, pelo apoio; Eliany Salvatierra pela divulgação dos trabalhos do Cala-boca já morreu; Sheila Bovo, pela capacidade de visão para além do convencional; Luana, Pardal, Jaime Rampazzo, Diogo 90, Mariana Moura, Marcelo Berg, pelos trabalhos de intensa criação, recheados de muito benquerer; Márcia Perígolo, pela lucidez; Sérgio Gomes, Ana Luísa Zaniboni, da OBORÉ, pelo companheirismo; Raquel 
Trajber, pela confiança; Tereza Diorio, Auira, Patrícia Mousinho, Bruno Pinheiro, Massao, Lúcia, Rangel, Clóvis, Maricota, Luli, Henrique Santana, Dudu Rombauer, pelos olhos inquietos que me fazem prestar mais atenção no que faço e digo; Rose Soffner e todos os alunos da Faculdade Sumaré, pela ampliação das propostas; Marcelo Brás, pela disponibilidade; César de Lucca, que me lembrou que respirar é importante; Elly Ferrari e Bianca Dettino pelo abstract; Zi, pela leitura e seleção de programas do anexo; Ma, pela transcrição; Ma Kz e Ma Manfredi pelo carinho expresso na criação dos DVDs anexos; Teresa Melo, pelas grandes e inesquecíveis caminhadas; Sandra Olivieri, Pablo Milanez, Atahualpa Yupanqui, Manuel de Barros e Fifi, minha netinha, por recarregarem minhas energias durante os meses de dezembro e janeiro; Prof. Marcos Ferreira Santos, pelo alargamento do horizonte; a todos os que custearam os meus estudos na Universidade de São Paulo, durante o Mestrado e o Doutorado. 
a poesia, a magia, a arte... as grandes sabedorias

não podem habitar corações medrosos

Plínio Marcos 


\section{RESUMO}

LOPES LIMA, Grácia. Educação pelos Meios de Comunicação: produção coletiva de comunicação na perspectiva da Educomunicação. 2009. 135 f. Tese (Doutorado) Faculdade de Educação, Universidade de São Paulo, São Paulo, 2009.

Esta tese tem como tema a produção coletiva de comunicação, na perspectiva da Educomunicação. Argumenta que os processos de criação, vivenciados em pequenos grupos, mais do que os produtos de comunicação que eles geram, podem contribuir para uma educação comprometida com a constituição de sujeitos autônomos. Para tanto, aponta a necessidade de a produção de comunicação ser considerada como direito humano a ser exercido por todas as pessoas, bem como as tecnologias e linguagens midiáticas serem utilizadas como instrumentos que possibilitam aos envolvidos no processo de criação reconhecer-se nas próprias palavras e imagens que produzem. Afirma que do exercício de envolvimento consigo e com o outro nasce a possibilidade de re-significarem suas histórias pessoais e coletivas. A autora fundamenta a tese, orientada pelos estudos de Educomunicação, da Pedagogia Libertária, da Comunicação Comunitária e dos Estudos do Imaginário. Utiliza a pesquisa-ação como metodologia, valendo-se das atividades de Educomunicação, desenvolvidas ao longo de mais de uma década, pelo GENS - Serviços Educacionais e pelo Projeto Cala-boca já morreu - porque nós também temos o que dizer! Por esses motivos, conclui que a Produção coletiva de comunicação, na perspectiva da Educomunicação pode ser considerada como Educação pelos Meios de Comunicação.

Palavras-chave: Educação, Comunicação, Educomunicação 


\section{ABSTRACT}

LOPES LIMA, Grácia. Educação pelos Meios de Comunicação: produção coletiva de comunicação na perspectiva da Educomunicação. 2009. 135 f. Tese (Doutorado) Faculdade de Educação, Universidade de São Paulo, São Paulo, 2009.

This thesis researches the collective production of communication, in the perspective of Educommunication. The research argues that the creation processes, shared in small groups, more than the communication products generated, contribute to a committed education with the constitution of the social person autonomy. The procedure points out the necessity of communication human right exercised by all the people, with technologies and mediatics language used as creation instruments, in order to recognize its own produced words and images. This work affirms that the involvement with yourself and the others resignificates the personal and collective histories. The thesis is guided in the studies of: Educommunication, "Pedagogia Libertária", Community Communication and Studies of the Imaginary. The methodology used follows the action-research that works the activities of Educommunication developed along more than one decade, by GENS - Serviços Educacionais and Projeto Cala-boca já morreu - porque nós também temos o que dizer! The research conclusion is that the Collective Production of communication, in the perspective of Educommunicaion is considered as Education by the Means of Communication.

Key words: Education, Communication, Educommunication. 


\section{SUMÁRIO}

1 CONSIDERAÇÕES INICIAIS

2 REFERENCIAL TEÓRICO NA PRODUÇÃO COLETIVA DE COMUNICAÇÃO - UMA VERTENTE DA EDUCOMUNICAÇÃO

2.1 Conceitos de educação 40

2.2 Conceito de comunicação 51

2.3 Conceito de educomunicação 59

3 CALA-BOCA JÁ MORREU - UMA METODOLOGIA PARA PRODUÇÕES COLETIVAS DE COMUNICAÇÃO, NA PERSPECTIVA DA EDUCOMUNICAÇÃO 60

3.1 Desdobramentos da ação educativa do GENS 65

3. 2 Caminhos da metodologia cala-boca já morreu 67

3. 3 Detalhamento da metodologia cala-boca já morreu 77

3. 4 Movimentos da metodologia cala-boca já morreu 83

4 O LADO DE DENTRO DO PROCESSO COLETIVO DE PRODUÇÃO DE COMUNICAÇÃO 


\title{
7 ANEXOS
}

\section{DVD 1 - CAMINHOS DA METODOLOGIA CALA-BOCA JÁ MORREU}

\author{
Saúde Mental
}

- "O alçapão indígena", criação da Oficina Ondas Paranóicas, São Paulo/SP.

- Entrevistas realizadas por participantes da Oficina de rádio

Ondas Paranóicas, durante o Desfile do Cordão Bibitantan, São Paulo/SP.

\section{Pedagogia do idoso}

- Trecho de um dos Programas de rádio "Embalos de domingo à tarde", criado por alunos participantes da UNATI - Universidade Aberta à Terceira Idade, da FITO/FEAO - Osasco/SP.

- Capas, editoriais e alguns artigos da Revista Engrama criados pela professora e alunos participantes da Disciplina Multimeios, na UNATI - Universidade Aberta à terceira Idade, da FITO/FEAO - Osasco/SP.

\section{Formação inicial de professores}

- Programa de rádio criado durante as aulas de Língua Portuguesa 1, por alunas do Curso de Pedagogia da Faculdade Sumaré/SP

- Vídeo-documentário "Eu, autor", criado por professores e estudantes do Curso de Pedagogia, da Faculdade Sumaré/SP 
sobre o processo de realização do TCC - Trabalho de Conclusão de Curso.

- PPD - Projeto Pedagógico-didático da Disciplina Língua Portuguesa 1, do Curso de Pedagogia, da Faculdade Sumaré/SP.

- PPD - Projeto Pedagógico-didático da Disciplina Tecnologia Educacional 1, do Curso de Pedagogia, da Faculdade Sumaré/SP.

- Fotonovela "Calçada do amor", criada por alunos, durante as aulas de Tecnologia Educacional 1, do Curso de Pedagogia, da Faculdade Sumaré/SP.

- Fotonovela "Tome uma atitude", criada por alunos, durante as aulas de Tecnologia Educacional 1, do Curso de Pedagogia, da Faculdade Sumaré/SP.

\section{Cultura}

Produção de vídeo

- "Paraty", criação de moradores do Município de Paraty, durante o I Festival Internacional de Cinema de Paraty/RJ.

- "1 minuto Paraty", criação de adolescentes moradores do Município de Paraty, durante o II Festival Internacional de Cinema de Paraty/RJ.

\section{Produção radiofônica com comunidades tradicionais}

- "Plantio" - música criada por moradores de comunidades da Estação Ecológica Juréia-Itatins - EEJI (SP) e seu entorno, para o Projeto Viola Peregrina, realizado pela MONGUE - Proteção ao sistema costeiro - SP/ Peruíbe. 


\section{Educação Ambiental}

- Programa de rádio, criado por professoras participantes do Programa de Educomunicação de Atibaia/SP.

- Programa de rádio, criado por Facilitadores Nacionais e Internacionais, participantes da II Conferência Nacional InfantoJuvenil pelo Meio Ambiente, realizada pelo Ministério da Educação e Ministério do Meio Ambiente.

\section{Educação não-formal}

- Vídeo-documentário, sobre o Projeto Rádio-Escola de Vargem Grande Paulista/SP, criação do GENS - Serviços Educacionais.

- "La hormiguita", vídeo criado por crianças, durante o Programa de Educomunicação de Sorocaba/SP.

- "X-burguer", vídeo criado por crianças, durante o Programa de Educomunicação de Sorocaba/SP.

- "Através dos sapatos conheçam pessoas", vídeo criado por crianças, durante o Programa de Educomunicação de Sorocaba/SP.

- "O beijo do vampiro", vídeo criado por crianças, durante o Programa de Educomunicação de Sorocaba/SP.

- "Vídeo sobre a praça", vídeo criado por crianças, durante o Programa de Educomunicação de Sorocaba/SP.

- "Os bichos", vídeo criado por crianças, durante o Programa de Educomunicação de Sorocaba/SP.

- "Nóis é fera!", programa de rádio criado por crianças, durante o Programa de Educomunicação de Sorocaba/SP.

- Transcrição do programa "Nóis é fera!",

- Cédula para escolha do nome da emissora de rádio, de escolas participantes do Programa de Educomunicação de Sorocaba/SP. 
- Contagem de votos para nome da emissora de rádio, de escolas participantes do Programa de Educomunicação de Sorocaba/SP.

- Grade de programação de emissoras de rádio, de escolas participantes do Programa de Educomunicação de Sorocaba/SP.

\section{O lado de dentro da produção coletiva de Educomunicação}

- "Processo" - vídeo-documentário, criação do GENS Serviços Educacionais, sobre o processo de criação de um programa de rádio, por um grupo de crianças e uma assistente de educação, participantes do Programa de Educomunicação de Sorocaba/SP.

\section{DVD 2: FONTES INSPIRADORAS}

- "Programa de rádio Porrada no ar"

Trechos relacionados à Cultura e ao Meio Ambiente

- "Projeto Cala-boca já morreu"

- Programa de rádio

Trecho do Bloco "Criança Ecologia"

"As aventuras da Julinha"

- Jornal

Edições 1, 2, 3 e 5

- Programas de televisão

Programa no 1

Programa no 4

- Vídeo

"A babá e as crianças"

"Delícias Nham-nham"

Foto-clipe "O meio", música de Luiz Tatit 


\section{Considerações iniciais}

Esta tese é um dos desdobramentos de um processo vivenciado pelo GENS Serviços Educacionais, desde 1995, quando criamos o "Cala-boca já morreu", com um grupo de crianças de 7 a 12 anos de idade que, por livre iniciativa, aceitou nosso convite para participar de um programa de rádio, que, mal sabíamos, daria início a uma história singular.

Depois de realizarmos com elas mais de 100 programas de duas horas, apresentados "ao vivo" na Rádio Cidadã, uma emissora comunitária da cidade de São Paulo, em 1996, passamos a desenvolver com o mesmo grupo a produção de jornal impresso, momento em que a proposta se ampliou, passando a constituir-se num projeto, dali para frente denominado "Projeto Cala-boca já morreu - porque nós também temos o que dizer!"

As duas ações, em menos de um ano, evidenciavam que crianças envolvidas com comunicação aguçavam com uma rapidez impressionante a capacidade de ouvir, ver e se concentrar no que juntas produziam. A cada preparação de programa para o rádio, de matéria nova para o jornal, mais e mais vontade mostravam por conhecer assuntos ligados à vida cotidiana, à natureza, às tecnologias, ao relacionamento entre as pessoas e o funcionamento das coisas do mundo.

Por esses motivos, em 1997, data de nascimento do Canal Comunitário da Cidade de São Paulo, recebemos, mais do que um novo convite, uma provocação para também desenvolver com o mesmo grupo uma terceira atividade, desta vez, ligada à linguagem audiovisual. Aceitamos a proposta, e, adotando os mesmos procedimentos metodológicos das duas experiências anteriores, realizamos quatro 
programas de quinze minutos, inteiramente feitos pelas crianças, que foram ao ar pela televisão.

Os resultados qualitativos observados no grupo cada vez mais surpreendiam: percepção mais aguçada os levava a maior elaboração do pensamento. Mais espontaneidade, menos medo de expor o próprio corpo, maior disponibilidade para conviver com a diversidade. Fortalecimento da auto-imagem e, conseqüentemente, maior capacidade de se colocar diante de diferentes tipos de pessoas, independente da idade, nível cultural ou posição social ocupada por elas.

Em pouquíssimo tempo, os meninos e meninas do Projeto mostravam que o domínio de equipamentos tecnológicos e da linguagem dos meios de comunicação poderiam ser instrumentos preciosos para a formação de indivíduos esclarecidos, altivos e autônomos.

Em suma: evidenciava-se que mais do que produzir comunicação, estávamos, em três diferentes espaços de comunicação comunitária, vivenciando um tipo especial de experiência, que àquela altura contava com a efetiva adesão das crianças - fator mais marcante da proposta. Elas não participavam das atividades porque seus pais queriam, suas professoras indicavam ou porque poderiam ficar famosas através das tantas entrevistas que passavam a conceder para a grande imprensa, inclusive internacional. Elas continuavam conosco porque gostavam das inúmeras oportunidades que se abriam e, principalmente, porque tudo que acontecia era fruto de intensa vivência de processos coletivos de criação.

Mas não só os pequenos se encantavam, se animavam e se fortaleciam com a proposta. Nós também nesse processo íamos solidificando sonhos e convicções. Aos poucos, materializava-se naquela proposta a possibilidade real de um tipo de educação pelos meios de comunicação que, efetivamente, poderia contribuir para a formação de gente autora de sua própria história.

Esses movimentos vivos do processo nos permitiram estruturar uma metodologia, a partir de então denominada Metodologia Cala-boca já morreu, que não tardaria a ser partilhada e vivenciada em outros espaços, como um estilo próprio de conceber e realizar práticas que aproximavam os campos da Educação e Comunicação, 
apontadas como pilares de um novo campo de intervenção chamado Educomunicação.

No ano 2000, os desdobramentos dessa iniciativa do GENS começaram. Fomos contratados pela Prefeitura de Vargem Grande Paulista para nesse município desenvolver o Projeto Rádio-Escola. No ano seguinte, fomos convidados a compor a equipe idealizadora do Projeto educom.rádio, do NCE - Núcleo de Comunicação e Educação da Escola de Comunicação e Artes da Universidade de São Paulo, onde durante dois anos assumimos a função de coordenadora educomunicacional, responsável pela seleção e formação da equipe multidisciplinar condutora do projeto, bem como pela idealização das atividades de rádio desenvolvidas pelos participantes do curso de formação. O município paulista de Sorocaba, no mesmo ano, nos contrata, através da Secretaria Municipal de Educação, para implantar os Projetos Rádio e Vídeo-Escola em toda rede municipal de ensino. Aí, como forma de partilhar as produções coletivas de comunicação, na perspectiva da Educomunicação das unidades escolares com a sociedade sorocabana, durante três anos, realizamos Mostras de Rádio e Vídeo-Escola, abertas também a pesquisadores do campo da Educomunicação.

Em 2002, apresentamos pela Escola de Comunicação e Artes da Universidade de São Paulo, a dissertação de Mestrado Educomunicação, Psicopedagogia e Prática radiofônica - estudo de caso do Programa de rádio Cala-boca já morreu, que muito colaborou para o aprofundamento teórico de nossos trabalhos.

Na seqüência, em 2004, as nossas atividades voltadas para a produção coletiva de imagem começam a despertar interesse de outras instâncias, que não só as educacionais. Vislumbrando, especialmente nos processos de produção de vídeos desenvolvidos pelo GENS a possibilidade de formação de um "novo olhar", fomos convidados, para desenvolver oficinas de vídeo durante os eventos de Cinema Nacional, realizados em Paraty, Rio de Janeiro. Durante três anos consecutivos, moradores da cidade, puderam, então, assistir suas próprias produções audiovisuais na mesma tela de cinema em que grandes diretores exibiam seus filmes.

A partir de 2005, o Projeto Cala-boca já morreu, que após dez anos de existência, continuava com muitos de seus pequenos fundadores, passa a ser uma organização 
não-governamental. Desde então, a convite do Ministério da Educação e Ministério do Meio Ambiente, passamos a realizar um trabalho de assessoria em Educomunicação para o Programa Juventude e Meio Ambiente e as três Conferências Nacionais Infanto-Juvenil pelo Meio Ambiente.

Doravante em parceria, as duas instituições - GENS e o Projeto Cala-boca já morreu - anualmente, oferecem cursos de formação em Educomunicação.

Essas experiências de mais de uma década voltadas para a produção coletiva de comunicação, na perspectiva da Educomunicação, com diferentes públicos crianças, adolescentes, jovens e adultos, em espaços de educação formal e nãoformal - têm levantado várias questões inquietantes, não só em quem produz e se reconhece como autor nas mensagens midiáticas que cria, como em quem acompanha o processo e percebe aí a possibilidade de as produções serem uma forma de conhecer/compreender as culturas de diferentes grupos sociais e envolverse com uma outra proposta que se vale das tecnologias e das linguagens dos meios de comunicação como instrumentos de educação.

À tarefa de realizar algumas reflexões sobre essas práticas é que nos dispomos nesta pesquisa.

\section{Tema da pesquisa}

Produção coletiva de comunicação, na perspectiva da Educomunicação, concebida como Educação pelos Meios de Comunicação.

\section{Problema}

Considerando que 
- "vivemos num mundo não meramente físico, onde a linguagem, a arte, o mito e a religião são fios que tecem o emaranhado da experiência humana" (CASSIRER,1994:48);

- os meios de comunicação, estando concentrados nas mãos de apenas alguns grupos, veiculam mensagens que levam os olhos e os ouvidos dos receptores para lugares distantes daqueles que habitam;

- educação resulta de um trabalho conjunto de toda a sociedade e, que, portanto, os meios de comunicação não definem, mas exercem fortes poderes sobre o que as pessoas pensam sobre si mesmas, sobre a percepção que têm da vida e da morte, assim como da organização da sociedade;

- produzir comunicação é direito humano de todas as pessoas, independente de idade, gênero, origem ou condição social;

- a comunicação comunitária aproxima as pessoas e pode contribuir para que elas se fortaleçam individual e coletivamente;

- pela ação sobre si mesmo e sobre o mundo, o ser humano é capaz de tomar consciência de si e, então, resignificar a vida;

- "algo mais se insinua no horizonte das ações comunicativas quando realizamos algo à nossa volta com o compromisso social de conviver mais dignamente" (FERREIRA SANTOS, 2004a: 72).

Considerando, enfim, que todo ser humano é produtor de cultura, concebida como "criação, apropriação, transmissão, interpretação dos bens simbólicos e suas relações" (FERREIRA SANTOS, 2004a: 61), o processo de produção coletiva de comunicação, na perspectiva da educomunicação, não seria uma maneira de envolver as pessoas em processos que possibilitem a elas se re-conhecerem como sujeitos que, de fato, são da sua própria existência? 


\section{Justificativa}

A educação formal, em certa medida, já se deu conta de que as questões relacionadas com a comunicação social também devem fazer parte de seu âmbito de interesse. Afinal, vão ficando nítidas as marcas de uma convivência intensa da comunidade escolar com vários sistemas de produção e distribuição de informação. Mais que nunca fica evidente quanto os meios de comunicação, especialmente os audiovisuais se integram, cada vez mais cedo, ao processo de formação das pessoas

"as novas gerações são leitoras da comunicação audiovisual ainda no estado intra-uterino. A mãe, quando está grávida, senta em frente à televisão, se emociona, passa para o feto aquelas impressões. Tudo vira história (...) as novas gerações são formadas nisso desde que abrem os olhos para o mundo. Já estão compreendendo aquilo que a televisão está mostrando, que o cinema está exibindo. Trazem isso para dentro da sala de aula, esse conhecimento, essa leitura. São todos pós-graduados em linguagem áudio-visual, quando entram analfabetos na escola (...)

(FRANCO, 1996:109)

Ocorre que estamos, pelos meios de comunicação mais populares, como rádio e TV, convivendo com sons e imagens que mostram realidades bem diferentes e distantes da nossa. As grandes empresas de comunicação retratam o mundo, indiferentes às culturas locais. Direcionam mensagens que distraem aqueles que os recepcionam, admirados, entorpecidos até, para se tornarem presas fáceis de um discurso que oferece uma "imagem de uma única cultura e de uma única história, ocultando a divisão social interna" (CHAUÍ, 1995: 296).

Essa política de comunicação social precisa ser compreendida. A lógica usada pelos que, à revelia da lei, se julgam proprietários dos sistemas de meios de comunicação, a rigor, concessões públicas, necessita ser conhecida pelos seus usuários. 
Igualmente, tem ampliado os estudos que aprofundam teoricamente as contribuições das práticas que aproximam Comunicação e Educação. Nesse sentido, vários países de todo mundo, dentre os quais o Brasil, já desenvolveram, há várias décadas, programas de leitura crítica dos meios, com a intenção de fortalecer a capacidade analítica, especialmente, de jovens receptores.

A par desses projetos de recepção crítica, destacam-se também vários programas educacionais que objetivam tornar os meios de comunicação ferramentas, instrumentos, através dos quais as pessoas, especialmente estudantes, possam se apropriar para comunicar seus próprios universos simbólicos.

Tais projetos propõem-se a incluir novas tecnologias e diferentes linguagens no âmbito da escola, incorporando-as ao dia-a-dia da sala de aula. Consideram a produção como uma possibilidade de a comunidade escolar passar a olhar e ouvir a si própria e, coletivamente, se envolver com a cultura local.

Colocando professores e estudantes em situação de diálogo constante a partir da necessidade de um fazer coletivo, de uma prática marcada pela diversidade de sentimento, idéias e modos de ser, essas ações colaboram ainda para a construção da intersubjetividade.

Este encontro intersubjetivo é amparado pelas intercomunicações extradiscursivas, ou seja, com outros elementos além da discursividade das palavras.

(FERREIRA SANTOS, 2003a:71)

Por fim, a tal consciência crítica, tão esperada quanto ao caráter ideológico dos meios de comunicação acabaria, assim, por essas práticas, sendo uma decorrência natural do processo, exatamente porque, ao produzirem e se apropriarem de todas as etapas de produção de comunicação, os sujeitos passam a dominar o funcionamento do sistema de meios. Provavelmente, por essa razão, verão o mundo da tecnologia e das mídias com recursos preciosos para o fortalecimento de indivíduos e grupos. 
Ismar de Oliveira Soares, na perspectiva da Educomunicação, identifica e define essa produção de meios como

práticas educomunicativas que buscam convergências de ações, sincronizadas em torno de um grande objetivo: ampliar o coeficiente comunicativo das ações humanas. Para tanto, supõem uma teoria da ação comunicativa que privilegie o conceito de comunicação dialógica, uma ética de responsabilidade social para os produtores culturais; uma recepção ativa por parte das audiências; uma política de uso dos recursos da informação de acordo com os interesses dos pólos envolvidos no processo de comunicação (produtores, instituições mediadoras e consumidores da informação), o que culmina com a ampliação dos espaços de expressão (SOARES, 2001a:2)

Assim concebidos, os processos de produção coletiva adentram o universo imaginário, objeto da Antropologia

Toda reflexão sobre um meio qualquer de expressão deve se colocar a questão fundamental da relação específica existente entre o referente externo e a mensagem produzida por esse meio. Trata-se de representação do real (...)

(DUBOIS, 2003:27)

Isto significa dizer que a produção coletiva de comunicação, resultante de processos criativos de determinados grupos humanos, moradores de um determinado lugar, num determinado tempo, são

um modo de as pessoas tornarem presente algo que está ausente uma representação, pois pensar a questão da representação é pensar nas significações que os humanos atribuem à realidade

(CHAUÍ, 1995:294) 
Uma vez externadas e partilhadas, as produções coletivas de comunicação não só atualizam o que já é passado, como possibilitam àqueles que as recepcionam, o reconhecimento do universo cultural de seu entorno. Nesse sentido, tais produções envolvem as pessoas numa educação de sensibilidade

(...) valendo-se das Artes (plásticas, musicais, literárias, videográficas e fílmicas) em que as imagens e os símbolos, articulados em narrativas, articulam por sua vez, o patrimônio histórico-cultural do humano.

(FERREIRA SANTOS, 2003a:53)

Encontrando-se a si mesmos e em um processo de aprendizagem contínua de diálogo com o outro, crianças, adolescentes e adultos tornam-se mais autoconfiantes, mais solidários, e, portanto, mais comprometidos consigo e com a história do seu tempo.

Por fim, por serem voltadas especialmente para pessoas leigas, tais práticas contribuem para o movimento de democratização dos meios de comunicação. Quanto mais circularem produtos de comunicação que expressem diferentes pontos de vista, maiores são as possibilidades de entendimento dos fatos e, consequentemente, de as pessoas definirem por si mesmas o que melhor thes convém.

\section{Objetivo}

Evidenciar a produção coletiva de comunicação, na perspectiva da Educomunicação como sinônimo de Educação pelos Meios de Comunicação. 


\section{Hipóteses}

A Produção coletiva de comunicação, na perspectiva da Educomunicação, ou Educação pelos Meios de Comunicação

a) possibilita o encontro com o repertório cultural cotidiano de seus realizadores;

b) desenvolvida a partir dos princípios propostos pela "Metodologia Cala-boca já morreu" possibilita uma relação mais solidária entre as pessoas;

c) pode contribuir para uma educação efetivamente comprometida com o fortalecimento do indivíduo e dos grupos;

\section{Metodologia da pesquisa}

Adotamos a linha de pesquisa-ação, uma metodologia de pesquisa social que se associa a uma forma de ação social coletiva orientada para a resolução de problemas ou de objetivos de transformação, baseada nos princípios defendidos por Michel Thiollent (2000).

A escolha dessa metodologia obedeceu critérios muito claros: era preciso encontrar um autor e um procedimento científico que combinasse com o que na prática já vinha acontecendo, com a reflexão e o tipo de preocupações que já vinham norteando, desde o início, as atividades do GENS - Serviços Educacionais. Não se tratava, pois, de enquadrar as propostas numa metodologia. Antes, era necessário encontrar afinidade entre a metodologia a ser adotada e as propostas que já existiam, considerando que os procedimentos anteriores não se modificariam somente porque se tornariam objeto de investigação de um trabalho acadêmico.

Assim, a adequação entre a linha da pesquisa-ação e as nossas atividades, assentou-se em quatro aspectos formulados por Thiollent. Em primeiro lugar, porque 
nesta pesquisa predomina uma busca de compreensão e de interação entre a pesquisadora e os membros das atividades investigadas. Ou seja, nos trabalhos de produção coletiva de comunicação, na perspectiva da Educomunicação, realizados pelo GENS e também pelo Projeto Cala-boca já morreu, a pesquisadora, também coordenadora responsável pelos projetos de ambas as instituições, se mantém em diálogo permanente com os diferentes públicos (crianças, adolescentes, jovens e adultos) envolvidos nas atividades mencionadas. Em todas as ações - objeto desta pesquisa, predomina o esforço da pesquisadora em contribuir para a expressão criativa para registro e veiculação da história dos grupos. Os procedimentos colocam em evidência não somente a participação ativa da pesquisadora, como igualmente dos integrantes dos projetos - que interagem entre si - e interagem com a coordenadora - desde o diagnóstico das situações que vivenciam até as etapas subseqüentes, incluindo a de considerações sobre as ações que juntos realizam. Tal como define Thiollent o papel do pesquisador nesse tipo de pesquisa é o de desempenhar papel ativo na reflexão sobre problemas encontrados pelos grupos, no acompanhamento das propostas que eles definem como melhores para resolução do que detectam e querem resolver, bem como participa da avaliação de todo processo de investigação equacionado na pesquisa.

O segundo motivo refere-se ao fato de a pesquisa-ação ser adequada como instrumento de investigação para grupos, instituições e coletividades de pequeno ou médio porte. As ações aqui estudadas caracterizam-se por serem realizadas com grupos reduzidos de pessoas, mesmo nos casos em que se trata de Programas de Educomunicação para redes de ensino municipais ou Conferências Nacionais, como se verá.

Partimos do pressuposto que a produção coletiva de comunicação, na perspectiva da Educomunicação pode aproximar as pessoas, para que juntas definam o que desejam tornar público sobre o grupo do qual fazem parte. Pensamos que a convivência em grupos reduzidos facilita a conversa. Buscamos, pela nossa atuação como coordenadora desses projetos, uma forma de organização das pessoas, que possibilite discutirem problemas, sonhos e projetos de/para suas comunidades. Esperamos, enfim, ao reunir as pessoas em pequenos grupos, possibilitar que cada um dos participantes, gradativamente, se aproprie de si mesmo, para que juntos decidam o rumo de suas próprias vidas. 
Em terceiro lugar, este estudo se calca na ação e reflexão de atividades do GENS e do Cala-boca já morreu - todas de base empírica. Nas palavras de Thiollent, trata-se de uma pesquisa voltada para a descrição de situações concretas e para a intervenção ou ação orientada em função de resolução de questões efetivamente detectadas nas coletividades consideradas.

Nesse sentido, a pesquisa-ação se mostra como a metodologia mais adequada para a realização deste projeto de pesquisa porque não nos parece haver "dedução do geral ao particular" nem "indução do particular ao geral". Fica evidente que os participantes e a pesquisadora-coordenadora vêm-se envolvidos numa proposta que apresenta movimentos em que se alternam constatações verificadas e já testadas que se repetem no presente, com outras que são reconhecidas no presente e reconhecidas como possíveis de serem repetidas em situações posteriores.

$\mathrm{Na}$ pesquisa-ação o conjunto de exigências científicas não obedece ao padrão convencional de observação, marcado pela separação entre pesquisador (observador) e grupos pesquisados (observados), não havendo possibilidade de substituição do primeiro, tampouco interesse em quantificar informação. Predomina a dialogicidade, isto é, entre o pesquisador e as pessoas implicadas na pesquisa prevalece a "intercomunicação", e o que se intenta é avaliar conjuntamente o que for sendo realizado, ao longo da história do grupo.

Por fim, a afinidade entre nossa proposta e a metodologia de pesquisa-ação se resume em considerar que a ação de pequenos grupos deve permitir ampliar a experiência, mas produzir conhecimento para além de seus realizadores, como forma de avançar o debate sobre questões de relevância para toda a sociedade.

\section{Os estudos de caso}

Produções coletivas de comunicação, na perspectiva da Educomunicação realizadas pelo Projeto “Cala-boca já morreu - porque nós também temos o que dizer!"; Oficinas de rádio Ondas Paranóicas; Revista Engrama; Programa de rádio Embalos 
de domingo à tarde, SP; Programas de Educomunicação dos municípios de Vargem Grande Paulista Sorocaba, Sorocaba, Piedade, Alumínio e Atibaia, SP; Programas de rádio do Projeto educom.rádio, São Paulo, SP; Oficinas de vídeo realizadas durante a Mostra Nacional de Cinema de Paraty, Rio de Janeiro; Oficina de rádio $O$ que aprendi com meus pais, Peruíbe, SP; Produções de rádio do Programa Juventude e Meio Ambiente, MEC e MMA; Produções de rádio das três Conferências Nacionais Infanto-Juvenil Pelo Meio Ambiente, MEC e MMA; Produções de rádio e fotonovela dos alunos de Pedagogia da Faculdade Sumaré, São Paulo, SP.

\section{Plano de trabalho}

No primeiro capítulo, num esforço inadiável de traduzir com as nossas próprias palavras as bases teóricas de que nos servimos nas produções coletivas de comunicação, na perspectiva da Educomunicação, apresentamos as concepções de Educação, de Comunicação e de Educomunicação, que embasam a ação direta de mais de uma década do GENS e do Projeto Cala-boca já morreu, valendo-nos, para tanto de alguns princípios da Pedagogia Libertária e da Comunicação Comunitária.

No segundo, reiteramos nosso compromisso anunciado no capítulo anterior, apresentando a Metodologia Cala-boca já morreu para a produção coletiva de comunicação, na perspectiva da Educomunicação, sistematizada ao longo da trajetória profissional empreendida pelas duas instituições que the deram origem e que atualmente vem sendo utilizada em diversas áreas do conhecimento, em diferentes localidades brasileiras.

No terceiro e último, apresentamos uma descrição subjetiva de um lugar de criação coletiva de um programa de rádio, vivenciado por um grupo de crianças do Ensino Fundamental e uma assistente de educação, como forma de ilustrar o que enfaticamente destacamos nos capítulos precedentes: que nas produções coletivas de comunicação às quais nos referimos, os processos são sempre mais importantes que os produtos, porque são eles - os processos - que colocam em evidência que entre as duas palavras - Educação e Comunicação, a que indica o rumo da 
Educomunicação, do nosso ponto de vista é a Educação. A Comunicação, por conseqüência, é o instrumento através do qual ela se materializa e torna visíveis as suas intenções. Daí considerarmos Educomunicação como sinônimo de Educação pelos Meios de Comunicação. Para tanto, realizamos uma descrição subjetiva de um vídeo que documentou o momento de criação de um programa de rádio, sob inspiração dos Estudos do Imaginário (BACHELARD, 1997; DURAND, 2001; FERREIRA SANTOS, 2004á; e RICOER, 1989). 


\section{Referencial teórico na produção coletiva de comunicação - uma vertente da Educomunicação}

O documento que serve de referência para a continuidade dos estudos sobre Educomunicação data de 1999. Trata-se de uma pesquisa de dois anos, empreendida pelo NCE - Núcleo de Educação e Comunicação da Escola de Comunicação e Artes, da Universidade de São Paulo, em parceria com pesquisadores da UNIFACS, Bahia, que buscava identificar os trabalhos relacionados com a inter-relação Comunicação e Educação e seus respectivos realizadores no âmbito da América Latina.

Dessa investigação interessa-nos destacar dois pontos. O primeiro diz respeito ao reconhecimento da existência de quatro áreas de intervenção, assim entendidas ${ }^{1}$ :

"Educação para a comunicação: (estudos de recepção), e os programas de formação dos receptores autônomos e críticos dos meios ("Mídia Education" ou "Media Literacy");

Mediação tecnológica na educação: procedimentos e reflexões a respeito da presença e dos múltiplos usos das tecnologias da informação na educação;

Gestão comunicativa: planejamento, execução e avaliação de planos, programas e projetos de intervenção social no espaço da interrelação Comunicação/Cultura/Educação;

\footnotetext{
${ }^{1}$ Trecho correspondente à $3^{\text {a }}$ hipótese da pesquisa. As anteriores referiam-se, respectivamente, à formação e desenvolvimento de um novo campo de intervenção social denominado Educomunicação e à de que sua estruturação dá-se de modo "processual, mediático, transdisciplinar e interdiscursivo".
} 
Reflexão epistemológica: estudos acadêmicos sobre a natureza do fenômeno cultural emergente, constituído pela inter-relação Comunicação/Educação"

(SOARES, 1999: 27)

O segundo ponto traduz a relação entre as áreas de atuação e a proporção de pessoas com elas envolvidas ${ }^{2}$

"50\% deles dedicavam-se à área dos estudos epistemológicos, isto é, desenvolviam algum tipo de pesquisa teórica no campo da interrelação em estudo;

$47,16 \%$ voltavam-se para projetos de educação para a comunicação, quer através de algum projeto específico quer da prática curricular normal;

$30 \%$ dedicavam-se ao uso das tecnologias na educação, especialmente ao uso do computador na sala de aula;

19\% desenvolviam atividades entendidas como gestão da comunicação no espaço educativo;

4\% correspondiam às atividades de comunicação cultural, especialmente ligadas a linguagens artísticas;

3\% a atividades identificadas como uso da comunicação em ações voltadas para a cidadania, melhoria da qualidade de vida e diversidade humana."

(SOARES, 1999: 59- 60)

Tais números indicam que quase a totalidade dos afeitos ao tema, na época, ocupava-se em entender as relações entre Educação e Educação de forma teórica; na seqüência, constata-se a predominância de uso do computador em ambiente

\footnotetext{
${ }^{2}$ Esses dados resultam da aplicação de questionários e entrevistas junto a 178 colaboradores de 14 países, sendo 67,61\% brasileiros e 32,29\% latino-americanos e espanhóis (SOARES, 1999:67).
} 
estritamente escolar, restando apenas 7\% de ações para a categoria genericamente denominada comunicação.

Dez anos passados, uma rápida consulta à internet ${ }^{3}$, recurso de valor incontestável para pesquisas na atualidade, torna evidentes: a popularização do termo Educomunicação e a inversão do observado nos anos de 1990, em particular no Brasil.

Numa velocidade surpreendente, disseminam-se os mais diversos tipos de execução de projetos e diminuem, na mesma proporção, as investigações teóricas, especialmente por parte de instituições acadêmicas que muito contribuiriam para o aprofundamento epistemológico do fenômeno emergente, não tivessem elas também se voltado para a prática, a exemplo da sociedade civil.

Eis o motivo que justifica este capítulo. Particularmente interessa-nos aqui realizar um esforço inadiável de aclaramento das concepções de Educação, de Comunicação e, por conseqüência, de Educomunicação, que embasam uma área (ou vertente) específica desse campo: a Produção coletiva de comunicação, doravante por nós também chamada de Educação pelos Meios de Comunicação.

Em outras palavras, a partir da reflexão sobre a nossa ação direta buscamos tornar explícitas questões como estas: de quê conceito de educação e de comunicação nos valemos para a produção coletiva de comunicação na perspectiva da Educomunicação? Por que chamamos o que fazemos de Educomunicação?

“(...) teoria e prática são algo indicotomizável, a reflexão sobre a ação ressalta a teoria, sem a qual a ação (ou a prática) não é verdadeira." (FREIRE, 1992:40)

Servem de inspiração inicial para as nossas reflexões o pensamento e a ação do filósofo brasileiro, Paulo Freire e do comunicador argentino-uruguaio, Mário Kaplún, especialmente as relativas às décadas de 1970 e 1980, quando ambos

\footnotetext{
${ }^{3}$ Em 23 de dezembro de 2008, quando digitada a palavra Educomunicação no Google, maior site de busca da internet, foram encontradas 46 páginas na web, correspondendo a 97600 citações; 37 páginas em português, o equivalente a 94700 menções ao termo, e 41 páginas no Brasil, totalizando 52.800 citações.
} 
desenvolviam, cada um a seu modo, estudos e práticas, respectivamente voltadas para uma educação de cunho libertador para as camadas populares e para a formação de receptores mais críticos e participativos.

Não é nossa intenção discorrer sobre a trajetória de nenhum desses dois grandes pensadores. Queremos apenas destacar, a partir do que pontuamos na ação deles, o que julgamos importante para este estudo: a necessidade de toda e qualquer ação dirigida para além de nós mesmos ser acompanhada, até mesmo por questão de respeito por aqueles a quem é dirigida, de num discurso sobre o próprio fazer, circunscrito no locus de quem a ação se destina.

"Mas o que é ser teórico? E porque leu e aprendeu alguma teoria, isso não quer dizer teórico. Isso é ser copiador, e ser papagaio, papagaio teórico. Eu prefiro fazer a teoria ancorada naquilo que deve ser, na prática. E a minha prática, obviamente toda prática fica ancorada numa certa teoria, e onde começa a gente não sabe. Quer dizer, quando é que eu começo a teorizar? Talvez no útero, ou na hora de nascer, talvez a gente comece a teorizar, e toda prática é resultado de uma teorização. Mas essa teorização não pode ser feita sem uma prática. E a coisa vai nessa relação, portanto, saber de que tipo de teoria a gente está propondo e de onde vem essa teoria. É muito importante que se fale de onde vem essa teoria."

(D’AMBRÓSIO, 1996: 1024 )

A esse esforço (ou essa obrigação) de traduzir com as nossas próprias palavras de onde vem a teoria de que nos servimos nas produções coletivas de comunicação, na perspectiva da Educomunicação, assumindo a responsabilidade pelo que isto significa, nos dispomos neste capítulo.

Ressaltamos que, ao apontar algumas pequenas passagens que relacionam Comunicação e Educação nos caminhos percorridos por Freire e Kaplún, por

\footnotetext{
${ }^{4}$ Trecho da fala de Ubiratan D’Ambrósio no Seminário de Educação Libertária, realizado em 1994, na cidade de Florianópolis, Santa Catarina, quando ele diz que convém cada participante fazer a sua apresentação, pois a trajetória da pessoa revela a teoria com a qual ela se identifica e, por isso, sustenta na sua prática.
} 
extensão, queremos manifestar nossa admiração por todos os que, como eles, não se movem pelo altruísmo, muito menos por oportunismo ditado por um modismo de época, mas que generosamente, dedicam suas vidas para a realização de um sonho: o de que sejamos um povo que opta pela autonomia e pela solidariedade.

Freire e Kaplún assumem explicitamente um compromisso guiado pela vontade de construção de uma América Latina que se recusa à "domesticação ou invasão cultural” (FREIRE, 2000a). Por esse motivo, não poderiam ficar alheios aos efeitos da comunicação sobre a vida dos latinoamericanos e a respeito desse tema se posicionaram. Ambos concebiam-na como um fenômeno social de estreita relação com a cultura, atribuindo a esta o sinônimo de ação humana sobre as coisas da natureza.

Tanto um quanto o outro demonstram saber que a comunicação, desde a sua origem, se constituiu pela estreita ligação com a noção de "integração da sociedade" (MATELLART, 1999), do ponto de vista econômico; que se relacionou inicialmente com a expansão das "redes materiais", dentre as quais as ferroviárias consideradas as grandes propulsoras do progresso, estendendo-se com o tempo às "redes espirituais", ligadas às finanças ${ }^{5}$, e, por fim à "gestão de multidões"6, ou seja, à necessidade de controle social das "massas" concentradas nas emergentes áreas urbanas.

Tinham conhecimento de que da metade do século XIX até a segunda guerra mundial, solidificou-se uma lógica de que o progresso só poderia atingir a periferia por meio da irradiação pelos valores de um centro (MATELLART, 1999:19), e que

\footnotetext{
${ }^{5}$ É de Claude Saint-Simon (1760-1825) a metáfora que compara a administração das cidades, nascidas do fluxo de mercadorias e de mão de obra, decorrente da Revolução Industrial, com a de um "sistema vivo". Tal qual o sangue circula no organismo, as sociedades-indústria exigiriam operações (vias de comunicação) que assegurassem a "circulação" do dinheiro e acelerassem o progresso. Para manter uma "vida unitária", através de um "sistema" de crédito eficiente, foi preciso criar as tais redes artificiais (as de comunicação-transporte ou "redes materiais" e as de finanças ou "redes espirituais"), que desempenhariam uma função organizadora desses novos espaços. (MATELLLART, obra citada, p.16)

${ }^{6}$ De acordo ainda com Mattelart (p.20), porque a "invasão" da população (chamada de "massa") nas cidades criou novos comportamentos, colocando em perigo toda a sociedade, foi preciso criar mecanismos de fiscalização e controle. A partir de 1827, pois, por contribuição de teorias geopolíticas o "espaço territorial" passa a ser considerado a força definidora das relações sociais mantidas com o Estado, dando origem ao termo "homem médio" (resultante de dados estatísticos), dali para a frente, servindo de referência para determinar possíveis "patologias" ou desequilíbrios sociais.
} 
essa teoria difusionista ou desenvolvimentista, propagada pelos Estados Unidos, era a mesma que se instalou nos países do cone sul, calcada na idéia de que as tecnologias serviam para a resolução de desequilíbrios sociais.

Paulo Freire, em meados dos anos de $1960^{7}$, quando exilado no Chile, já denunciara as consequências desse pensamento no momento em que naquele país se realizava um processo de desenvolvimento de uma possível sociedade agrária (FREIRE, 1992). Para fazer entender, tanto os males advindos da importação (ou da permissão à invasão) dessas idéias, quanto para revelar a não neutralidade da ação de quem as aplica, é que ele propôs uma reflexão sobre o termo extensionista, assim chamado o trabalho dos agrônomos junto aos camponeses chilenos:

“(...) a ação extensionista envolve, qualquer que seja o setor em que se realize, a necessidade que sentem aqueles que a fazem, de ir até a outra parte do mundo, considerada inferior, para, à sua maneira, normalizá-la. Para fazê-la mais ou menos semelhante a seu mundo. Daí que, em seu 'campo associativo', o termo extensão se encontre em relação significativa com transmissão, entrega, doação, messianismo, mecanicismo, invasão cultural, manipulação, etc. $E$ todos estes termos envolvem ações que, transformando o homem em quase 'coisa', o negam como um ser de transformação do mundo. Além de negar, como veremos, a formação e a constituição do conhecimento autênticos. Além de negar a ação e a reflexão verdadeiras àqueles que são objetos de tais ações ${ }^{8}$."

(FREIRE, 1992: 22).

\footnotetext{
${ }^{7}$ A Revolução Cubana, de 1959, de inspiração martiniana (José Martí) e marxista, tornara-se paradigma para vários movimentos rurais e urbanos de países como Paraguai, Argentina, Brasil, Chile, Peru e Equador dominados por ditaduras militares, que disseminavam a miséria, a violência e o cerceamento de liberdade.

${ }^{8} \mathrm{O}$ autor, nesse momento do texto, vale-se dos conhecimentos linguísticos do genebrino Charles Bally, discípulo de Saussure (defensor da idéia de que os significados dos termos são circunscritos num determinada estrutura), sobre "campo associativos". De acordo com esse conceito haveria uma rede de associações, baseada em relações muito diversas entre os conceitos como semelhança, contigüidade e subordinação.
} 
De outra parte, com os mesmos propósitos freireanos de contribuir para a conscientização dos povos latinoamericanos, Kaplún também passou a denunciar as características da Comunicação Social ou "indústria da comunicação", como propõe Bordenave (1982), sob influência de uma teoria funcionalista, mecanicista, formulada na década de 1940 pelos estadunidenses Lasswell e Shannon (COHN, 1978), num momento crucial em que os Estados Unidos buscava de todas as formas a manutenção e fortalecimento do sistema capitalista.

Coloca em prática cursos de "Leitura Crítica" (BORTOLIERO,1996), junto às camadas pobres da população de países como Peru, Uruguai, Venezuela e Argentina, como meio de esclarecer-lhes que os empresários da comunicação (detentores dos meios de transmissão e controladores dos conteúdos das mensagens), seguem uma fórmula semelhante à lógica matemática ${ }^{9}$ para atingir uma única grande meta: motivar a compra de produtos e serviços, de uma maneira rápida e massiva.

Mario Kaplún não tardaria muito, contudo, à conclusão de que o tom denuncista dessa proposta não mudaria os hábitos de consumo dos meios por parte da população pobre. Em vez de alertar sobre os efeitos nocivos dessa comunicação, passou, então, a desenvolver com os pequenos agricultores, organizados em sindicatos e cooperativas, uma prática de uso dos meios de comunicação com finalidade educativa, deslocando-os do papel de receptores para o de também produtores de comunicação. ${ }^{10}$

Mais uma vez é preciso ressaltar que o novo encaminhamento da sua proposta resultou da revisão crítica de seus pressupostos e reafirmou as convicções ideológicas de seu proponente. O Cassete Fórum se configurou, assim, como um método, ou seja, um meio de intervir numa realidade específica, buscando intencionalmente transformá-la. Retomando Diaz Bordenave (1982: 19), para quem

\footnotetext{
${ }^{9}$ Essa estrutura linear, até hoje ensinada e exercitada na maioria das escolas de comunicação, busca a solução de uma questão ("fonte", "quem?"), passando por um processo racional, lógico e por etapas, até uma solução definitiva ("destino", "efeito") (MATTELART, 1999).

${ }^{10}$ O projeto piloto do Método Cassete Fórum, idealizado por Mário Kaplún, se realiza no Uruguai, com apoio do CIID - Centro Internacional de Investigações para o Desenvolvimento, de abril de 1977 a março de 1978, de onde toma dimensão nacional e depois se estende a outros países, incluindo o Brasil.
} 
"la democratización de la comunicación debe comenzar (y terminar) en el dialogo participativo del pequeño lugar”, o próprio Kaplún declarou que

\begin{abstract}
"es para organizaciones de esta naturaleza para las que ha sido concebido y diseñado el Cassete-Foro. Para ponerlo a su servicio como instrumento, como arma de organización. "
\end{abstract}

(KAPLÚN, 1984: 11)

Quando se trata de Educação, esses dois pensadores igualmente explicitaram a dimensão teórica de sua prática. Para Paulo Freire o "alfabetismo", definido por Weffort, na apresentação de Educação como prática de liberdade, como "tomar posse do idioma" (FREIRE, 2000a: 13), possibilita aos homens reconhecerem-se como produtores de cultura, isto é, de entenderem que a realidade resulta sempre da intervenção de sujeitos sobre ela. A grandiosidade do domínio da linguagem está exatamente na possibilidade de, através dela, compreender que os homens "não estão apenas no mundo, mas com o mundo" (FREIRE, 2000a: 112), ou seja, que são todos dotados da capacidade de transformação da realidade.

"Pensávamos em uma alfabetização que fosse em si um ato de criação, capaz de desencadear outros atos criadores. Numa alfabetização em que o homem, porque não fosse seu paciente, seu objeto, desenvolvesse a impaciência, a vivacidade, característica dos estados de procura, de invenção, de reivindicação."

(FREIRE, 2000a: $112^{11}$ )

Daí que para ele, Educação não se limite ao planejamento de ações para os mais jovens, nem tampouco para os ambientes escolares. Educação, como sinônimo de "leitura do mundo", pressupõe um movimento permanente que envolva todas as

\footnotetext{
${ }^{11} \mathrm{O}$ autor está se referindo às primeiras experiências de alfabetização de adulto, realizadas em Pernambuco, durante os primeiros anos da década de 1960.
} 
pessoas nas suas mais variadas fases da vida. Os mais velhos, em particular, porque possuem mais experiência vivida, levados pela consciência crítica e não pela manipulação (FREIRE, 2000), podem tomar decisões e através delas mudar a realidade.

Já em Mário Kaplún, a dimensão educativa de sua ação logo se anuncia na própria definição do Método Cassete-Fórum:

"El Cassete-Foro es un sistema de comunicación para la promoción comunitaria y la educación de adulto, puesto al servicio de organizaciones populares - rurales y urbanas - centrales cooperativas, centros de educación popular etc."

(KAPLUN, 1984: 9)

Palavras como "participação", "integração", "mobilização" deixam claro que seu trabalho se propõe a ser

“ Un instrumento útil (...) para dinamizar a las organizaciones populares y ayudarlas en su expansión y su fortalecimiento para desarrollar la capacidad organizativa de las bases y sus procesos de autoeducación política."

(KAPLUN, 1984: 13)

Ou seja, "(...) introducir elementos de reflexión, de conciencia crítica, de estímulo a la libertad y a la solidaridad" (KAPLÚN, 1984:45), na formação de homens e mulheres das camadas populares, consumidores de uma comunicação massiva que tenta mantê-los apáticos ou "completamente analfabetos" (Freire, 2000: 110) diante dos problemas que vivem, para que se assumam como sujeitos e, uma vez organizados, mudem a história. 
Esses dois intelectuais atuaram, enfim, contra a miséria instaurada na América Latina, onde os governos, centralizados nas mãos de uma elite opressora e violenta, controlavam os recursos econômicos em favor de si mesmos. Daí a razão pela qual os dois, com veemência, denunciaram a invasão cultural especialmente importada dos Estados Unidos, tão ardilosamente difundida pelos meios massivos de comunicação, que serviam de apoio às idéias antidemocráticas das elites do poder.

Freire e Kaplún, em suma, vislumbravam na Educação e na Comunicação, respectivamente, a possibilidade de promoverem nas massas a consciência crítica necessária para uma mudança na estrutura do Estado. 


\section{Conceitos de Educação}

Inspiramo-nos em princípios da educação e da pedagogia libertárias ${ }^{12}$, ou seja, numa teoria que entende a educação como um dos elementos que pode contribuir para a transformação da sociedade. Nos estudos voltados às concepções pedagógicas, a libertária se encontra entre as consideradas "contra-hegemônicas",

“(...) aquelas orientações que não apenas não conseguiram se tornar dominantes, mas que buscam intencional e sistematicamente colocar a serviço das forças que lutam para transformar a ordem vigente visando a instaurar uma nova forma de sociedade."

(SAVIANI, 2005:22)

Compromissado com o fortalecimento do indivíduo, nosso trabalho se realiza em espaços de educação escolar, como também nos não-formais, incluindo-se entre estes, o de comunicação comunitária, ocupados basicamente por leigos, quer em educação quanto em comunicação

"Vislumbrávamos a possibilidade de conceber e realizar naquela emissora $^{13}$ uma educação descentralizada, efetivamente construída e validada pelos participantes dos programas. Uma educação que promovesse um aprendizado que fosse além dos conteúdos escolares, em geral, centralizado na figura de um único professor."

(LOPES LIMA, 2002: 65)

\footnotetext{
${ }^{12}$ Essa educação sustenta-se em dois pilares: a "afirmação da liberdade e a negação radical da dominação e da exploração" (GALLO, 2007: 20).

${ }^{13}$ Referimo-nos à Rádio Cidadã, emissora comunitária onde, em 1995, como fruto da parceria com o GENS, nasceu o Projeto Cala-boca já morreu, a origem do nosso trabalho especificamente voltado para a Educomunicação.
} 
Dentre os princípios de inspiração libertária que se fazem presentes nas produções coletivas de comunicação, destacamos no momento estes:

\section{Individualidade}

Num tempo em que a publicidade utiliza os mais variados artifícios para estimular o consumo de bens materiais e serviços, convencendo as pessoas a se destacarem da multidão, é compreensível que individualidade seja confundida com individualismo. A lógica do discurso de mercado assenta-se na classificação das pessoas por categorias. Quanto mais incitadas a serem distintas umas das outras, maior será a busca desenfreada por produtos que as façam se sentirem incomuns. Do elogio à diferença resulta, dentre outros males, a insatisfação, a pouca ou nenhuma solidariedade, o viver exclusivamente para si, o egoísmo, enfim.

Individualidade significa o oposto de individualismo. Origina-se do latim individùus, indivisível, uno, que não foi separado. Nessa afirmação encontra-se a idéia de que

“(...) o indivíduo é o universo em si. Pode dizer-se que a individualidade é a consciência do indivíduo de ser o que é, e de viver esta diferença. É um aspecto inerente a todo o ser humano (...)."

(GOLDMAN, 2007: 37)

As reiteradas vezes em que afirmamos querer colaborar para o fortalecimento do indivíduo vêm desta convicção: a de que aquele que se sabe indivíduo considera-se inteiro. E quem é pleno não é vulnerável a apelos externos.

Diferentemente do individualismo, que gera rivalidade, a individualidade aproxima os iguais. Do encontro de iguais pela inteireza nascem o companheirismo e a solidariedade, respectivamente derivados do latim panis, 'pão' e solidus 'sólido, maciço, firme, inteiro, pleno; resistente', ou seja, a ação permanente de partir o pão e de se fortalecer com (ele)s. Daí, que o tipo de relação entre indivíduos é, por 
natureza, complexa: de uma independência resultante de uma organização dinâmica e sui generis

"Quando falamos dos seres vivos, já estamos supondo que há algo em comum entre eles, do contrário não os colocaríamos na mesma classe que designamos com o termo "vivo". O que não está dito, porém, é qual é a organização que os define como classe. Nossa proposta é que os seres vivos se caracterizam por - literalmente produzirem de modo contínuo a si próprios, o que indicamos quando chamamos a organização que os define como autopoiética."

(MATURANA e VARELA, 2002: 52)

Por esses motivos às atividades que chamamos de produção de comunicação atrelamos o adjetivo "coletiva" - para enfatizar que as palavras grupo e indivíduo não se contrapõem. Ao contrário: a relação entre ambas é de complementaridade.

\section{Afirmação da liberdade}

Bakunin (1980) afirma que os seres humanos aprendem a ser o que são no tipo de sociedade em que vivem.

A sociedade que sonhamos e com a qual esta proposta busca colaborar, reiteramos, é formada por pessoas (ou indivíduos) autônomas, capazes de se livrar de toda e qualquer tentativa de opressão sobre aquilo que nos caracteriza como seres humanos que somos. 
Uma das formas de colaborarmos para a consolidação desse ideal se reflete no modo com que propomos que aconteçam as produções de comunicação: elas precisam ser realizadas coletivamente, em pequenos grupos ${ }^{14}$.

Consideramos que os grupos que se dispõem a produzir comunicação formam uma pequena sociedade onde todos os tipos de inter-relações se fazem presentes. Há quem neles se coloque como mandante, quem se acomode e nada realize, quem obedeça com muita facilidade, quem boicote, quem se faça de vítima etc. Daí serem, na nossa concepção, espaços dinâmicos marcados pela simultaneidade destes movimentos realizados pelo indivíduo: o de perceber como os outros se relacionam entre si, consigo e com a tarefa definida pelo próprio grupo, e o de cada um compreender como particularmente lida com os outros, consigo e com a tarefa que não foi definida somente por ele.

Aqui, à tarefa - produção de comunicação - atribuímos o sentido de elemento desencadeador das tantas reflexões necessárias para que, em grupo, cada indivíduo reconheça a sua efetiva participação para a manutenção ou a transformação da vida, entendida tanto como atributo da natureza, como das ações dos homens entre si. Em outras palavras, a tarefa é um meio através do qual buscamos recuperar o sentido latino do termo educação ex ducere - que significa dizer algo que é conduzido para fora, para o exterior.

"Portanto, algo interno, profundo, que nos caracteriza a todos, pois que é a partilha com a espécie humana e, ao mesmo tempo, aquilo que mais nos diferencia com relação aos outros com quem convivemos, pois que é o mais específico de nós, nossa condição de pessoa humana com seu próprio caráter, suas características, sua singularidade. Esta condição de possibilidade, esta potência interna, que em nossa condição latina, chamamos de 'humanitas'.

Porque trata-se da percepção de que a educação possui um fim em si mesma e não se adequa a finalidades instrumentais (exceto nas manipulações políticas e demagógicas). A educação não é um meio

\footnotetext{
${ }^{14}$ Consideramos que mesmo nas ações de Educomunicação em forma de oficinas, projetos ou programas, independente do número total de pessoas envolvidas, é necessário dividi-las em grupos de no máximo 10 pessoas.
} 
para atingir algo (educação para o trabalho, educação para a cidadania, educação para a terra, educação para a inclusão etc...)"

(FERREIRA SANTOS, $2005: 1$ )

Assim a metodologia (ou estilo) que adotamos para seguir a trilha que escolhemos, assegura a cada pessoa em particular que ela mesma decida o que quer fazer, como deve realizar o que pretende, opine e participe ativamente de todas as etapas de produção da mensagem. Ninguém é obrigado a nada. A ação parte da autoadesão. Está embutida nesse procedimento a idéia de que a pessoa, com o tempo, conseguirá perceber no grupo e com o grupo, como ela lida com a liberdade.

Entenda-se que o princípio de liberdade aqui é concebido como fim, mas também como meio, uma vez que sem o seu exercício constante não se torna possível. A esse exercício de aprender a lidar com a liberdade é que se voltam os encontros dos grupos. Porque eles - os exercícios dos encontros - também são meios, não podem ser confundidos com ações espontâneas.

Todas as reuniões dos grupos são intencionalmente planejadas para a realização de uma tarefa específica: a produção coletiva de comunicação. No caso dela não se concretizar (possibilidade prevista e não rara), a ausência do produto de comunicação deve transformar-se em objeto de entendimento sobre os motivos que impediram a sua realização.

Por isso afirmamos que não se trata de juntar pessoas para fazer um produto, no sentido fabril do termo, em que cada um faz uma parte e ao final, basta um especialista juntar, a seu modo, os pedaços até dá-lo como acabado. O processo é mais importante que o produto $^{15}$ porque é no espaço da convivência densa entre o começo e o fim da criação que se dão os embates de idéias e ficam visíveis os diferentes graus de assimilação da estrutura do tipo de sociedade onde vivem os grupos.

\footnotetext{
${ }^{15}$ Essa afirmação se encontra em Considerações sobre os processos e os produtos, uma das etapas da Metodologia Cala-boca já morreu, objeto do capítulo II desta tese.
} 
Ou seja, o compromisso maior da ação educativa pelos meios de comunicação é com o que eles desencadeiam nos grupos para que, compreendendo os valores embutidos nas suas próprias relações sociais, tenham condição de transformá-las.

Por essa razão dizermos também que o papel de quem se responsabiliza pelos grupos identifica-se com o de mediador ${ }^{16}$ de relações sociais. Pressupõe, além de afinidade ideológica com a proposta de intervenção, que ele tenha sensibilidade e disponibilidade interior para aguçar a escuta, e maturidade suficiente para extrair da experiência vivencial o material de que precisa para problematizar os temas da vida social que nos grupos se estampam. Desempenhar bem essa função exige também que essa pessoa esteja mobilizada para entender e querer transformar as relações, que na sociedade competitiva em que vivemos, aprendemos a estabelecer com diferentes tipos de autoridade.

"O processo pedagógico de uma construção coletiva da liberdade é um processo de desconstrução paulatina da autoridade."

(GALLO, 2007: 25)

Retomando Bakunin (1980), naturalmente nascemos prontos para conviver em qualquer tipo de sociedade. Porém, nem todos os tipos de sociedades nos querem como homens livres que nascemos. No caso da Educação pelos Meios de Comunicação, optamos pelo conceito de homem que nasceu livre e por uma pedagogia que se propõe a contribuir para preservar esse princípio básico da existência humana, cientes de que a autonomia só é possível àqueles que se negam a cumprir ordens que não sejam as próprias, mas que sabem também que a liberdade somente se consolida nas tensas relações que estabelecem, ao longo da vida, necessariamente com o outro.

${ }^{16}$ As criações coletivas de comunicação, na perspectiva da Educomunicação não requerem especialistas. Estaríamos, caso aceitássemos essa possibilidade, retrocedendo ao tempo em que ainda as relações entre Comunicação e Educação não eram concebidas como um "campo interdiscursivo e transdisciplinar" (SOARES, 2004). Esperamos que nesse campo venham atuar pessoas estudiosas, da academia ou não, que por serem inquietas e inconformadas com a realidade social, se disponham a usar os meios de comunicação como forma de explicitar o tipo de relação social que, em geral, mantemos, pautada por valores que transformam as relações humanas em objetais, semelhante às que mantemos com mercadorias e que nos afastam do que nos caracteriza como seres humanos: a individualidade. 
Daí que a educação, para nós, é sinônimo de processo

(...) que visa trazer à tona o mais específico da pessoa: fazer com que ela seja ela mesma. Tarefa impossível sem um preâmbulo dialógico. Tarefa impossível sem a paixão pelo humano que é o ponto de partida. Tarefa irrealizável sem o cumprimento de um destino comum: paixão pelo saber...philo-sophia diriam os gregos. Mas, este saber feminino caracterizado pela Sophia, não é um conhecimento instrumental que se utiliza, independentemente, da própria pessoa e em relações de poder e dominação. Todo ao contrário, como já ressaltado por vários pensadores, é um sabersabor que remonta à arqueologia culinária da cognição: cozer o alimento, depurá-lo, temperá-lo, apropriar-se dele... para quê? Para compartilhar na mesa da amizade. Podemos educar eruditos. No entanto, educar é um verbo que somente pode ser conjugado na primeira pessoa. Portanto, educar-se já é um ato sábio que assim procede pois aprendeu na convivência com outro sábio ou sábia. Os sábios e sábias engendram-se."

(FERREIRA SANTOS, 2005:20)

\section{Igualdade de direitos}

“(...) as diferenças naturais dos indivíduos não devem se transformar, necessariamente, em desigualdade social, mas (...), antes, podem se tornar o fundamento e a riqueza em uma sociedade libertária"

PROUDHON, apud CODELLO, 2007:93

Não raro o conceito de igualdade é tratado como um fim, alcançável, por meio de determinadas ações bem planejadas e implementadas, em favor da maioria. 
Imbuídos desse espírito, muitos são os discursos e práticas voltados para a promoção da inclusão de parcelas da população, consideradas à margem da sociedade.

$\mathrm{Na}$ base desse raciocínio movido por sentimentos de piedade pela infelicidade de outrem se encontra uma disposição, mesmo que não consciente, de não alterar a causa das mazelas, mas apenas escamoteá-las para aperfeiçoá-las ainda mais. Não fosse isso, não seriam direcionadas por quem se assume em situação de superioridade em relação aos favorecidos.

Encontra-se aí, na consternação, uma das formas mais requintadas de manter as desigualdades sociais. Levando o homem - objeto da ação de inclusão - a se sentir menor, incutindo nele a gratidão, o altruísmo contribui para que ele se sinta incapaz de manter a si mesmo. Não há forma mais eficiente de acabar com princípios humanos do que este que torna o homem presa fácil, dependente de poderes superiores.

A síntese radical desse raciocínio nos leva a concluir que faz total sentido os praticantes de tais misericórdias serem associados a promotores da tolerância (do latim tolero, 'suportar um fardo, sofrer, aturar'), e suas ações serem consideradas "de inclusão", vocábulo também latino, derivado de inclusio, ónis, 'encerramento, prisão'. Nada mais adequado para essas tentativas de manter as coisas inalteradas do que a criação de barreiras e grades, especialmente as simbólicas.

Para nós a igualdade de direitos não se limita à supressão da pobreza material. Reiteramos que nosso compromisso é contribuir com a formação de sujeitos, que, utilizando das tecnologias e das linguagens dos meios de comunicação como instrumentos, se reconheçam nas imagens e sons que produzem.

Para tanto, trabalhamos através das tecnologias (gravadores, câmeras, computadores etc.), com a linguagem não reduzida à palavra codificada pelas gramáticas, 
(...) mas linguagem do corpo inteiro, pois é essa corporeidade que é solicitada e engajada na atitude comunicativa. São elementos constituintes dessa linguagem: o próprio corpo em sua inteireza, o contexto da comunicação, os interlocutores e as mensagens transitadas entre eles.

(FERREIRA SANTOS, 2004a: 36)

Partilhamos do princípio que o deslocar-se do papel de consumidores de informação para o de produtores de comunicação é direito humano a ser exercido por todas as pessoas, independente de idade, gênero, origem condição social, ou qualquer outro tipo de classificação.

Quando exercido esse direito, a partir da vivência de processos coletivos de criação, a palavra veiculada se irradia, carregada de sentido, aumentando a possibilidade de retornar com maior energia aos ouvidos de quem a profere e de entrar em sintonia com os ouvidos daquele a quem se dirige.

É desse exercício constante de falar, se escutar e ser ouvido, atentando para o discurso que se vai montando através das palavras que traduzem sonhos, inquietações e necessidades reais, que os próprios indivíduos acabam por entender que a comunicação é um direito imanente dos seres humanos e, como tal, inalienável, ou seja, não pode ser cedido ou barganhado, sob pena de destituir o homem da sua própria natureza humana. Vale dizer, nesse tipo de proposta, a palavra não é doada ou permitida, nem tampouco retirada. Ela é sabiamente assumida pelos indivíduos dispostos à altivez e autonomia.

\section{Co-gestão}

Não basta idealizar um sólido arcabouço teórico, escolher bons métodos e capacitados profissionais para implantar projetos ou programas na perspectiva da Educomunicação. 
A construção de um outro tipo de convivência social exige que todos os envolvidos experimentem os efeitos do seu discurso, para que, de fato, aprendam

“(...) o respeito pelo outro como ele é, com todas as suas diferenças. Não adianta respeitar o outro porque ele é parecido com você, isso não é virtude. Virtude é respeitar o outro com suas diferenças porque ele é outro."

(D’AMBRÓSIO, 1996: 107)

Isso pressupõe entender que o que o outro é vai além do que ele aparenta, do que ele ostenta, do cargo que ele ocupa, porque respeito não se atrela a postos de comando. Num grupo que reúna pessoas de idades muito diferentes nem o mais novo tem que acatar o que diz o mais velho, tampouco este tem que necessariamente aceitar o que o outro propõe. É este o significado que damos à expressão horizontalidade das relações nos processos de produção de comunicação, na perspectiva da Educomunicação.

Ou seja, não há e nem pode haver alguém que manda frente a outros que obedecem, alguém que decide o que os outros devem cumprir. Nessa proposta de organização social não há e nem pode haver a figura do estrategista definindo, delimitando ou inventando ações para que outras pessoas avancem, recuem, envolvam e atuem de modo a atingirem os fins por ele previstos e determinados. Quem estabelece as estratégias são os participantes do grupo, tendo em vista os motivos que os levaram a se agrupar, assim como os objetivos que querem alcançar.

(SOARES, 2008)

Orientados pelos princípios da co-gestão, os indivíduos que assumem a função de mediadores das relações sociais dos grupos sabem disso. Por isso não ocupam o papel burocrático de apaziguar as tensões cotidianas, como forma disfarçada de 
salvaguardar as hierarquias. Não são conciliadores, nem fazem acordos para evitar conflitos que venham desestabilizar o controle da situação.

Porque também eles estão envolvidos com a necessidade de nos livrarmos todos dos fortes ranços da autoridade, impregnados na maioria de nós, em vez de anular os embates, colocam todos eles à tona, para serem problematizadas pelo grupo.

Agir assim reforça a capacidade de julgamento e provoca um sentimento de independência. Faz com que o homem seja capaz de decidir por si e é único método que pode fazer dele, verdadeiramente, um indivíduo - não uma criatura cuja fé está implícita, mas alguém capaz de exercitar sua própria compreensão.

(GODWIN, 1981:250)

Os indivíduos sabem, pela voz do mediador, inclusive, que esse procedimento é intencional; que nesse exercício de aguçamento das contradições se encontra a possibilidade de, aos poucos, cada participante do grupo se fortalecer e aprender a diferenciar ofensas pessoais de discussão de idéias. O que se espera pela cogestão é que todos, ao longo do processo, entendam que amenizar conflitos significa apenas "ceder um pouco de poder (...) um dos melhores meios de aumentar sua sujeição", causando "a impressão de influir sobre as coisas" (TRAGTENBERG, 1989:15). 


\section{Conceito de Comunicação}

A experiência-piloto que deu origem aos trabalhos mencionados neste estudo deriva de parcerias $^{17}$ entre uma instituição educacional e três tipos de mídia ${ }^{18}$ nãocomercial (ou meios de comunicação comunitários): uma emissora de rádio, uma rede de jornais de bairro e uma televisão comunitária. Nosso compromisso, portanto, desde o início, está diretamente relacionado com idéias e práticas da comunicação comunitária. Através delas sabemos ser possível realizar os princípios de uma educação voltada para a constituição de sujeitos, como delineamos neste estudo.

Em se tratando do mundo da informação, no âmbito das grandes empresas de comunicação, o jornalista francês, Ignácio Ramonet (2003) aponta que já não é mais possível distinguir as fronteiras entre informação (imprensa, rádio, agência de notícias), comunicação (ou cultura de massa: telenovela, quadrinhos, cinema, música etc.) e publicidade (propaganda, tomada no seu sentido político).

$\mathrm{Na}$ atualidade, os governos comunicam, as empresas comunicam, possuem jornais, rádios, têm porta-vozes midiáticos, têm estrutura de imprensa e é cada vez mais difícil para nós não identificar estes elementos como parte formadora do mundo da comunicação.

(RAMONET, 2003:243)

Ainda segundo Ramonet,

\footnotetext{
${ }^{17}$ O histórico dessas parcerias é encontrado no capítulo II.

${ }^{18}$ Mídia deriva de mass media (meios de comunicação de massa), termo usado nas pesquisas realizadas nos Estados Unidos sobre comportamento eleitoral, propaganda e opinião pública, entre os anos de 1920 e 1940. (Wolf, 2003: 3-49).
} 
O sistema midiático (...) é o aparelho ideológico da globalização. É o sistema que, em certa medida, constitui o poder de inscrever, no disco rígido de nosso cérebro, o programa para que aceitemos a globalização. Esse sistema ideológico, esse aparato ideológico global, é o aparelho midiático em seu conjunto. Quer dizer, o que a imprensa diz a televisão repete, a rádio repete, e não apenas nos noticiários, mas também nas ficções, na apresentação de um tipo de vida que se deve apresentar.

RAMONET, 2003: 246)

Nesse universo, a informação é mais uma mercadoria regida pelas regras do mercado, o que faz com que seja remota a possibilidade de, através dela, as pessoas se tornarem mais esclarecidas. Além de circularem numa rapidez absurda, essas informações já nem precisam mais ser compradas. Agora, as grandes corporações se incumbem de oferecê-las gratuitamente, sem sequer serem solicitadas, posto que quem paga por elas já não é mais o leitor, e sim, a publicidade $^{19}$.

Completando o ciclo dessa lógica, a informação passou a ser transmitida por todos os veículos, por meio de discursos montados com frases curtas, simples, que apelam para a emoção, transformando o jornalismo em entretenimento. Não exigindo atenção, pensamento, reflexão, crítica, a mídia globalizada busca infantilizar a todos (CHAUÍ,1995: 19)

Esses dados tornam-se mais graves e preocupantes, quando os aproximamos da realidade brasileira, onde ainda prevalece, ao lado de um alto índice de analfabetismo funcional, o monopólio da comunicação ${ }^{20}$. Invertendo os gêneros

\footnotetext{
${ }^{19}$ A fusão de grandes empresas de comunicação com as de entretenimento (Time Warner e América on line, por exemplo), configurou o que o autor chama de "empresas midiáticas", que passaram a vender consumidores a seus anunciantes, diferentemente do tempo em que as empresas jornalísticas vendiam informação para o público consumidor (RAMONET, 2003)

${ }^{20} \mathrm{O}$ mercado da comunicação no Brasil concentra-se em 11 grupos empresariais: Globo, Abril, O Estado de SPaulo, Folha de SPaulo, RBS (Zero Hora), Jornal do Brasil, SBT, Record, Bandeirantes, Rede TV e Gazeta Mercantil (ARBEX, 2003: 396). O Projeto Donos da Mídia reúne dados públicos e informações fornecidas pelos grupos de mídia para montar um panorama completo da mídia no Brasil, onde são detalhadas diversas informações sobre os seguintes tipos de veículos: emissoras e retransmissoras de TV; rádios AM, FM, Comunitárias, OT e OC; operadoras de TV a cabo, MMDS e
} 
(novelas dissimulando-se de documentários e telejornais transmitindo notícias com a linguagem da publicidade e das telenovelas), apresentando os fatos desconectados da economia e da história, a mídia "não apenas propaga a violência, como constitui, ela própria, uma violência organizada pelas elites contra a nação” (ARBEX, 2003: 386).

Diante desse quadro, estaríamos vivendo uma época marcada pela "incomunicação", segundo Touraine (1998), para quem o potencial da comunicação comunitária estaria, exatamente, na possibilidade de "recomunitarização" das sociedades contemporâneas, contribuindo para a recuperação da identidade, abalada pelos efeitos imprevisíveis dos mecanismos da globalização.

Já para nós, o grande potencial dos meios comunitários de comunicação está na possibilidade deles ampliarem as já evidentes relações entre Comunicação e Educação, incorporando as propostas de Produção coletiva de comunicação, na perspectiva da Educomunicação, entre suas atividades.

Através de parcerias entre escolas e organizações civis voltadas para práticas educativas, as mídias comunitárias podem fazer circular entre a comunidade as mensagens produzidas por seus próprios moradores. Seguramente, esta é uma maneira de evidenciar, de um lado, o potencial educativo dos meios e, de otimizar a capacidade comunicativa das instituições voltadas para a educação, de outro. Tais acordos podem traduzir em ações concretas os objetivos da Educomunicação como uma proposta de efetiva intervenção social.

Além dessa possibilidade de receber novos parceiros, que por si só, já demonstra afinidade com os princípios de cooperação e solidariedade, fundamentais para o fortalecimento de indivíduos e grupos, outras características das mídias comunitárias apresentam afinidade com o tipo de Educação que propomos.

DTH; canais de TV por assinatura; e as principais revistas e jornais impressos. Disponível em http://donosdamidia.com.br . Acesso em 19 de janeiro de 2009. 


\section{Abertura para projetos experimentais}

Como não há pressão de anunciantes ${ }^{21}$ no planejamento de suas atividades, as pequenas instituições de comunicação podem adotar critérios próprios para definir o que querem e devem ou não realizar.

Essa configuração torna possível a veiculação de matérias, programas e projetos que fujam do padrão praticado pela maioria das grandes empresas de comunicação, como é o caso, por exemplo, dos Projetos do tipo RádioEscola $^{22}$, em que os participantes podem vivenciar todas as funções necessárias para a realização de programas ao vivo, ou previamente gravados, dentre as quais a locução, atendimento ao ouvinte, cobertura jornalística de campo e operação técnica de equipamentos de transmissão.

Oferecer experiências como essas aos mais jovens, equivale ao que Proudhon chamou de "atividade laboriosa" ou

(...) um direito deles de conhecer tudo, de ver tudo, de provar cada coisa; o seu dever é aquele de realizar, com alegria e audácia, todas as tarefas que as necessidades da sociedade e o serviço interno em uma grande oficina exigem: tal é o compromisso do aprendizado e da lei da igualdade.

PROUDHON (apud CODELLO, 2007: 96)

Mas não só para propostas educacionais as mídias comunitárias estão abertas. Projetos de valorização das culturas locais, de cuidados com o meio

\footnotetext{
${ }^{21}$ O artigo 18, da Lei 9612/98, que regula as rádios comunitárias, não permite que elas tenham anunciantes: "As prestadoras do Serviço de Radiodifusão Comunitária poderão admitir patrocínio, sob a forma de apoio cultural, para os programas a serem transmitidos, desde que restritos aos estabelecimentos situados na área da comunidade atendida."

${ }^{22}$ A Rádio Comunitária 8 de dezembro, de Vargem Grande Paulista, além de veicular os programas criados coletivamente pelas crianças das séries iniciais do Ensino Fundamental, igualmente abriu espaço para as professoras e coordenadoras das escolas participantes do Projeto Rádio-Escola (ano 2000).
} 
ambiente, de divulgação de artistas da região, de incentivo ao esporte amador são alguns outros exemplos de atividades possíveis de compor as atividades dos meios comunitários de comunicação.

\section{Atuação de não-profissionais}

A comunicação comunitária pode romper com todos os ditames postulados por especialistas em comunicação. Nesse espaço são benvindos todos os moradores da região que quiserem exercer o direito de produzir comunicação, sejam eles especialistas do ramo, crianças ou velhos.

Pelo fato de o rádio e a televisão adotarem o nível coloquial da língua oral para as apresentações, abrem-se possibilidade para que, inclusive, os analfabetos neles possam atuar em condição de igualdade com os demais comunicadores sociais.

(...) as pessoas envolvidas em tais processos desenvolvem o seu conhecimento e mudam o seu modo de ver e relacionar-se com a sociedade e com o próprio sistema dos meios de comunicação de massa. Apropriam-se das técnicas e de instrumentos tecnológicos de comunicação, adquirem uma visão mais crítica, tanto pelas informações que recebem quanto pelo que aprendem através da vivência, da própria prática.

(PERUZZO, 2002)

São inúmeras as possibilidades de rompimento gradativo com todo tipo de padrão de comunicação e de atuação de comunicadores, nas pequenas mídias. Os sotaques de cada região podem, enfim, deixar de ser motivo de chacota e vergonha. Respeitando os regionalismos, outras podem ser as entonações de voz, em contraposição à mídia comercial, na qual os repórteres e apresentadores mal se diferenciam pelo traje que usam. 
Do ponto de vista jornalístico, as notícias locais, realizadas e comentadas por gente que conhece o entrevistado e o contexto histórico-geográfico do fato, podem levar os receptores a prestar mais atenção no que está sendo informado. Ou seja, esse procedimento aponta a possibilidade de se inverter a lógica usual da mídia comercial que, ao produzir notícia "faz de conta" que informa. Aqui, o noticiarista não interpreta o papel de informante. Assim como quem o escuta, assiste ou lê, ele também está interessado em entender melhor as questões que dizem respeito à vida que "de verdade" ele e os receptores levam em suas pequenas localidades.

Não nos iludamos, contudo, que essas possibilidades venham a acontecer rapidamente. Elas não acontecem por milagre. Não bastam os meios e as técnicas. Estamos tratando de comunicação como meio de educação, sinônimo de longo processo. Não podemos esquecer que nosso país, como outros latino-americanos, viveu (e ainda vive) uma história bastante similar.

Marcado por una sociedad y una educación autoritarias, que lo llevan a verse a si mismo como ignorante e intelectualmente inferior, acostumbrado a delegar la interpretación de sus problemas a otros más "sabios", el campesino tiende a restar valor a su propio pensamiento. Varios de los participantes nos comentaron que, durante las discusiones de sus respectivos grupos, algunos compañeros más de una vez expresaban ideas interesantes, reflexiones, juicios, incluso iniciativas; pero, llegado el momento de grabar las conclusiones, el grupo dejaba caer esos aportes sin recogerlos porque "nos parecía que no valían a pena", que estaban fuera de tema, que no tenían interés ni relevancia ${ }^{23}$

(KAPLÚN, 1984: 85 )

Quanto mais entendermos essas questões, mais visíveis se tornam as possibilidades de envolver as pessoas numa educação pelos meios de comunicação. As produções coletivas, colocando as pessoas em contato com

\footnotetext{
${ }^{23}$ Mário Kaplún, nesse trecho relata um depoimento de um participante do Cassete-Fórum, para ilustrar que o exercício da comunicação grupal revela os tipos de relação sociais estabelecidas ao longo da história.
} 
a própria vida, podem desencadear processos de interlocução. Nesses encontros vigora a possibilidade do exercício da escuta profunda de si e do outro - sentido maior da comunicação.

\section{Viabilidade econômica}

Permuta é a forma que mais viabiliza parcerias com as mídias comunitárias, o que, por si só, não é uma novidade do mundo dos negócios. Ocorre que aqui se trata de pequenos colaborando com outros pequenos, e isto muda tudo. Não se trata de mais uma fórmula para impedir prejuízo ou simplesmente para tirar proveito de devedores. A permuta simboliza o brio, a persistência, a vontade de ser o que se escolheu ser - independente. Tática de sobrevivência, de sonho, de apoio mútuo, de projeto ousado.

Nos meios de comunicação comunitários não existe patrão nem empregado. Quem deles participa são pessoas que se auto-convocam para atuar como seus co-laboradores. Ou seja, optam por trabalhar juntos, em condição de igualdade, movidos por objetivos comuns.

O dinheiro - fruto desse trabalho - não se recebe, não se ganha. Portanto, não há doador, tampouco quem espere e agradeça pela doação. A sobrevivência advém do esforço e do interesse de cada um. Combinado o valor do horário ou do espaço para manter a atividade na programação, cada um busca apoio junto aos pequenos comerciantes da região, vendendo anúncio ou fazendo diferentes tipos de escambo. 


\section{Horizontalidade da comunicação}

A participação das pessoas na produção e transmissão das mensagens, nos mecanismos de planejamento e na gestão do veículo de comunicação comunitária contribui para que elas se tornem sujeitos, se sintam capazes de fazer aquilo que estão acostumadas a receber pronto, se tornam protagonistas da comunicação e não somente receptores.

PERUZZO, 2002

Não existe dono dos meios de comunicação comunitários. Não se admite quem deles queira se julgar proprietário. Assim, respeitadas as decisões tomadas coletivamente, todo morador tem direito de participar diretamente não só da programação, como igualmente da sua administração. Mas não somente os que ocupam o espaço físico das mídias comunitárias desempenham papel ativo nesse tipo de comunicação.

Os receptores também co-laboram para a materialização de uma comunicação efetivamente comunitária, que reúne as pessoas em torno de objetivos comuns. Aqui eles não são números que transformam a audiência em mercadoria a ser vendida para anunciantes, por isso seus discursos não sofrem a interferência de produtores que estão nos bastidores. Eles dizem o que querem dizer, do seu jeito, com as suas próprias palavras, porque, efetivamente, também são produtores de comunicação. 


\section{Conceito de Educomunicação que adotamos nas produções coletivas de comunicação}

Entre as duas palavras - Educação e Comunicação, a que indica o rumo da Educomunicação, do nosso ponto de vista é a Educação. A Comunicação, por consequência, é o instrumento através do qual ela se materializa e torna visíveis as suas intenções. Daí considerarmos que, nas atividades de Produção coletiva de comunicação, Educomunicação é sinônimo de Educação pelos Meios de Comunicação. 


\section{Cala-boca já morreu - uma metodologia para produções coletivas de comunicação, na perspectiva da Educomunicação}

Este capítulo trata da Metodologia Cala-boca já morreu para produções coletivas de comunicação na perspectiva da Educomunicação. Apresenta uma breve retrospectiva do contexto em que ela nasce, seus colaboradores, a sua trajetória e a forma com que vem sendo apresentada para diferentes grupos interessados em entender e colocar em ação os pressupostos de uma das vertentes desse novo campo do conhecimento chamado Educomunicação.

Um galo sozinho não tece uma manhã: ele precisará sempre de outros galos. De um que apanhe esse grito que ele e o lance a outro; de um outro galo que apanhe o grito que um galo antes e o lance a outro... 
A década de noventa marcou um período importante para a história da comunicação social nacional. Em especial

(...) no ano de 1995, o Brasil descobriu as rádios comunitárias (...) havia 'muito mais vozes no ar' (...) algo inédito na história do país, não enquanto experiência de rádio livre, cujo pioneirismo remonta o início da década de setenta, mas pelo elevado número de emissoras demonstrando uma disposição de ocupar as ondas, numa aberta contestação ao controle oligopolizado dos meios de comunicação de massa".

(PERUZZO, 1998:2)

Entre essas emissoras estava a Rádio Cidadã, situada no Jardim Bonfiglioli, Bairro do Butantã, zona oeste da cidade de São Paulo, que começou suas atividades, em julho desse ano, sob responsabilidade da Associação Cidadã e comando de Luci Martins ${ }^{24}$.

No mesmo mês de julho, com a Rádio Cidadã estabelecia-se a primeira parceria do GENS - Serviços Educacionais ${ }^{25}$ para viabilizar iniciativas que uniam Educação e Comunicação. O GENS se responsabilizava por criar e dirigir produções de cunho educacional para compor a grade de programação da emissora e esta assumia a sua veiculação. Nasciam, então, os programas de rádio Porrada no ar e Cala-boca já morreu, formados por um grupo de dez adolescentes, de 13 a 16 anos, e outro grupo de 10 crianças, de 7 a 12 anos, respectivamente. O primeiro, diferente do programa das crianças, além de mim, coordenadora de ambos, contava com a mediação do Psicólogo Edson Fragoaz (LOPES LIMA, 2002: 63-64). Implantava-se, a partir daí

\footnotetext{
${ }^{24}$ Dados da Secretaria de Comunicação Eletrônica do Ministério das Comunicações informam que dentre as 6952 emissoras existentes no Brasil, nas diversas modalidades de serviço de radiodifusão, encontram-se 2898 rádios comunitárias com outorgas no país, até agosto de 2007. Disponível em http://www.mc.gov.br/005/00502001.asp?ttCD CHAVE=9719\# . Acesso em 14 de maio de 2008.

${ }^{25}$ O GENS - Serviços Educacionais é uma empresa de consultoria em Educação e Educomunicação, fundada em 1986.
} 
"um conjunto de ações voltadas para o planejamento, execução de atividades intencionalmente educativas, criadas pelo princípio da ação e do diálogo comunicativos."

(SOARES, 1999:40)

Durante dois anos, até seu fechamento pela Polícia Federal ${ }^{26}$, a Rádio Cidadã incluiu em sua programação semanal quatro horas "ao vivo", dedicadas à veiculação desses dois referidos programas, tempo suficiente para imprimir as características mais significativas da metodologia ora em questão. ${ }^{27}$

Em 1996, uma nova parceria, desta vez com a REDE A de Jornais de Bairro, sob direção de Antonio Carlos Escudero, possibilitou desenvolver com as mesmas crianças do programa de rádio o Jornal Cala-boca já morreu, um pequeno encarte tamanho sulfite, frente e verso, distribuído gratuitamente em 25 mil domicílios, pelo Jornal do Bairro do Butantã. ${ }^{28}$ Ao repertório dos participantes do Cala-boca já morreu, concebido a partir dessa ação como um Projeto acrescentam-se a máquina fotográfica e o computador, tecnologias novas para a maioria dos pequenos produtores de comunicação.

Dois anos depois, em 1998, estabelecia-se a terceira parceria. Repetindo os mesmos procedimentos anteriores, o Centro Dehoniano de Comunicação empresta ao GENS, durante três meses, um spot de iluminação, uma câmera

\footnotetext{
${ }^{26}$ A oficialização da comunicação comunitária como um serviço regular somente aconteceria em fevereiro de 1998, com a Lei 9212/98, assinada pelo então presidente Fernando Henrique Cardoso e pelo Ministro das Comunicações, Sérgio Motta. Contudo, isso não bastava para que as rádios de baixa potência tivessem o direito de existir. A Rádio Cidadã só obteria a outorga de autorização de funcionamento, pelo prazo de dez anos, em dezembro de 2008, 11 anos depois de seu fechamento, através da portaria do Ministério das Comunicações, publicada no dia 18 de dezembro de 2008. Apesar de o Governo Federal dar seu aval para funcionamento das rádios, ainda é preciso, para a legalização definitiva e início das transmissões, passar pela aprovação do Congresso Nacional, que tem 90 dias para analisar o assunto. Findo esse prazo, as rádios receberão uma "outorga provisória" e poderão entrar no ar": Disponível em http://www.obore.com/acontecelntegra.asp?cd=1450. Acesso em 20 de dezembro 2008.
}

\footnotetext{
${ }^{27}$ Um dos blocos do Programa de Rádio Cala-boca já morreu pode ser ouvido no DVD, em anexo.

${ }^{28}$ Quatro edições do Jornal Cala-boca já morreu estão disponíveis no DVD, em anexo.
} 
de vídeo, duas baterias e os serviços técnicos para que em sua ilha de edição finalizássemos quatro edições de 15 minutos do Programa de Televisão Cala-boca já morreu ${ }^{29}$ exibidas no recém-inaugurado Canal Comunitário da Cidade de São Paulo. ${ }^{30}$

Graças a essas combinações políticas de uso democrático dos recursos da informação para atender aos interesses dos pólos envolvidos no processo de comunicação voltada, em última análise, para a formação de cidadãos criativos e efetivamente comprometidos com a comunidade local (SOARES, 2001), foi possível ampliar aos poucos o alcance da referida metodologia.

Constatar que crianças mostravam-se capazes de, em tão pouco tempo, aprender com facilidade diferentes linguagens e tecnologias de três importantes meios de comunicação, deslocando-se do papel de consumidoras $^{31}$ para serem produtoras de comunicação, acrescida da real possibilidade de inserir essas produções nos meios de comunicação comunitários locais, muito nos animaram e incitaram a ampliar a experiência vivida. Passamos, então, dali para frente, a partilhar o mesmo procedimento para produções coletivas de comunicação com outros públicos, como uma maneira de contribuirmos para aumentar o número de pessoas esclarecidas sobre o poder da comunicação comunitária nas mãos de quem aprende a se ouvir, a dialogar com o outro e a se fortalecer como grupo. Essa nova etapa contribuiria, principalmente, para consolidar o caráter teórico-prático de

\footnotetext{
${ }^{29}$ O primeiro e o último programa desta série encontram-se também disponíveis no DVD, em anexo.

${ }^{30}$ O Art. $23^{\circ}$ da Lei $9.877 / 95$ estabelece que operadoras de TV a Cabo devem tornar disponíveis "canais básicos de utilização gratuita", também chamados de "canais de acesso público": um canal legislativo municipal / estadual, um canal reservado para Câmara dos Deputados, um canal para o Senado Federal, um canal universitário, um canal educativo / cultural, um canal comunitário e um canal reservado para o Supremo Tribunal Federal.

Na cidade de São Paulo, o citado Canal Comunitário da Cidade de São Paulo assumiu o nome TV Aberta de São Paulo, que se auto-define como um canal comunitário de acesso público, fundada por um consórcio entre a OAB São Paulo, a Editora Vida e Trabalho e a TV Interação. Disponível em www.tvaberta.com . Acesso em 23 de dezembro de 2008.

${ }^{31}$ De acordo com o Painel Nacional de Televisores do Ibope 2007, a criança brasileira, entre quatro e 11 anos, passa, em média, 4 horas, 50 minutos e 11 segundos por dia em frente à telinha. Em média, $85,50 \%$ das crianças entre 6 e 12 anos assistem à tevê diariamente, segundo a pesquisa da Kiddo's Brasil 2006. Dessas, $90 \%$ dizem que gostam muito de assistir à programação televisiva, e 77\% afirmam que ficam o tempo que desejam em frente aos televisores. Disponível em http://www.alana.org.br/CriancaConsumo/Comunicacao.aspx?page=1\&v. Acesso em 18 de julho de 2008.
} 
nosso estilo de atuação, que dali para frente adotaríamos em todos os trabalhos de Educomunicação, chamados por nós de "Educação pelos Meios de Comunicação". 


\section{Desdobramentos da ação educativa do GENS}

Em maio de 1998, o GENS é convidado para apresentar a experiência de três anos do Projeto Cala-boca já morreu no I Congresso Internacional sobre Comunicação e Educação, promovido pelo WCME - World Council for Media Education - Madrid, Espanha e NCE ${ }^{32}$ - Núcleo de Comunicação e Educação, do Centro de Comunicação e Artes da Escola de Comunicação e Artes da Universidade de São Paulo. O evento reuniu especialistas, produtores, professores e empresários dos cinco continentes envolvidos em projetos voltados para os diversos âmbitos do campo da inter-relação Comunicação e Educação.

Fizemos parte do grupo 12, destinado às experiências de Produção Cultural e Promoção da Cidadania, dando destaque na apresentação a duas hipóteses até então norteadoras dos nossos trabalhos:

a) As práticas que relacionam Comunicação e Educação, quando desenvolvidas em grupo sob mediação não-centralizadora, desencadeiam no grupo a aprendizagem de uma relação social pautada pela escuta de si e do outro e pelo respeito à diversidade;

b) O uso dos recursos da comunicação social em práticas educativas é uma das maneiras mais eficazes de desenvolver o potencial criativo de crianças e adolescentes;

Desde então, pelo trabalho que desenvolvíamos com o Projeto Cala-boca já morreu, passamos a integrar o rol dos atores sociais, identificados pelo Núcleo de Educação e Comunicação da ECA - Escola de Comunicação e Artes da USP, como

\footnotetext{
32 O Núcleo de Comunicação e Educação - NCE nasceu em 1996, no espaço da Universidade de São Paulo, reunindo um grupo de professores de várias universidades brasileiras interessadas na interrelação entre Comunicação e Educação. Apóia projetos de pesquisa de alunos de programas de pósgraduação em diversos níveis; mantém projetos que desenvolvem a educomunicação através de diversas atividades; realiza eventos para difundir e debater a educomunicação e temas relacionados. Disponível em http://www.usp.br/nce/. Acesso em 09 de dezembro de 2008.
} 
realizadores das tais práticas sociais anunciadoras da existência da Educomunicação.

Uma vez considerados como colaboradores na constituição desse novo campo, sentimo-nos na obrigação de documentar de forma sistemática o modo como trabalhávamos. Essa tarefa de analisar com rigor as nossas próprias ações foi importante, pois nos permitiu reconhecer que havíamos concebido um modo de atuar que já poderia ser considerado como uma metodologia, especialmente porque explicitava a opção teórica que fazíamos ao problematizarmos as relações entre Educação e Comunicação, objeto da pesquisa-ação que o GENS vinha desenvolvendo. 


\title{
Caminhos da metodologia Cala-boca já morreu
}

\author{
Saúde Mental
}

O hospício é construído para controlar e reprimir os trabalhadores que perderam a capacidade de responder aos interesses capitalistas de produção.

Franco Basaglia, ${ }^{33}$

A convite do Psicólogo Edson Fragoaz, co-responsável pelo Programa de rádio Porrada no ar, na época integrante da equipe técnica do Centro de Atenção Psicossocial ${ }^{34}$ "Prof. Luis da Rocha Cerqueira" - CAPS Itapeva - São Paulo/SP, no final de 1996, iniciamos pela Associação Franco Basaglia ${ }^{35}$ uma oficina de rádio com usuários adultos da saúde mental, motivados que estávamos com o trabalho que vínhamos realizando com crianças e adolescentes. Os encontros eram semanais e duravam uma hora e meia. Os participantes da oficina, criavam, gravavam, ouviam e teciam comentários

\footnotetext{
${ }^{33}$ Médico psiquiatra italiano, integrante do movimento antipsiquiatria, cujas idéias propagaram-se nas décadas de 1960 e 1970, para o qual "... a psiquiatria desde seu nascimento é em si uma técnica altamente repressiva que o Estado sempre usou para oprimir os doentes pobres..." Disponível em http://www.ccs.saude.gov.br/memoria\%20da\%20loucura/Mostra/basaglia.html. Acesso em 16 de julho de 2008. Parte da Memória da Psiquiatria no Brasil encontra-se disponível em http://www.ccs.saude.gov.br/memoria\%20da\%20loucura/Mostra/apresenta.html. Acesso em 2 de novembro de 2008.

${ }^{34}$ Os Centros de Atendimento Psicossocial (CAPS) oferecem tratamento para pessoas de sua área de abrangência, que sofrem com transtornos mentais, psicoses, neuroses graves e demais quadros, realizando o acompanhamento clínico e a reinserção social dos usuários pelo acesso ao trabalho, lazer, exercício dos direitos civis e fortalecimento dos laços familiares e comunitários. Disponível em http://portal.saude.gov.br/portal/saude/cidadao/area.cfm?id area=925. Acesso em 10 de agosto de 2008.

${ }^{35}$ Fundada em abril de 1989, essa organização não-governamental reuniu usuários, familiares e profissionais dos serviços de saúde mental, estudantes e outros interessados na questão da saúde mental. Desenvolveu diversos projetos de caráter científico, cultural e de sociabilidade, boa parte deles em parceira com o CAPS, através do Núcleo de Projetos Especiais. Disponível em http://www.picica.com.br/tese silvio.pdf. Acesso em 30 de dezembro de 2008.
} 
sobre as produções realizadas em um gravador manual, tipo repórter. Periodicamente, o mesmo grupo apresentava o Programa Ondas Paranóicas ${ }^{36}$ com uma hora de duração, ao vivo, na Rádio Cidadã, tal qual os do Porrada no ar e do Cala-boca já morreu.

Mesmo depois de fechada a Rádio Cidadã, continuamos com a oficina e o grupo passou a, periodicamente, se apresentar em algumas das festas Multiplacidade, promovidas no casarão da Rua Itapeva, como é conhecido o mencionado CAPS "Prof. Luis da Rocha Cerqueira", e a gravar entrevistas em outros eventos ligados à luta antimanicomial.

Essenciais no processo de desinstitucionalização ${ }^{37}$ e reinserção social dos egressos dos hospitais psiquiátricos há um consenso sobre a necessidade de a sociedade conviver de forma mais harmônica com as pessoas acometidas por sofrimentos mentais. Movidos por essas convicções, depois do ano 2000, a oficina deixa de acontecer no CAPS Itapeva e se transfere para a casa do Cala-boca já morreu, no Bairro do Jaguaré.

Contra os paradigmas tais como alienação, degeneração ou ainda doença mental como sinônimo de incapacidade de juízo, de razão, de participação social, O Ondas Paranóicas pode ser considerado uma das ações culturais que servem para a escuta e o reconhecimento das potencialidades do sujeito cruelmente colocado à margem da sociedade brasileira. ${ }^{38}$

\footnotetext{
${ }^{36}$ Alguns desses programas estão disponíveis em www.portalgens.com.br/ondas.

${ }^{37}$ Somente em 2001 foi aprovada Lei Antimanicomial n.․ 10.216, extinguindo os manicômios e criando os Centros de Atenção Psicossocial (CAPS) que, junto com os Serviços Residenciais Terapêuticos (Portaria GM n.ำ106, de 11/2/2000), integram a Política de Saúde Mental do Ministério da Saúde.

${ }^{38}$ No DVD, em anexo, estão disponíveis duas produções desse grupo.
} 


\section{Pedagogia do idoso}

...Surgia então o desafio. A Professora Grácia pedia a todos a participação e que os textos fossem próprios. $O$ grupo nunca havia passado por essa experiência. Mas, como mágica, os textos e idéias foram surgindo. Alguns artigos eram tão atuais que se fazia necessária uma publicação rápida. E, com muito esforço da equipe $e$ colaboração dos amigos, a Revista Engrama no 3 surgiu, publicada justamente na semana em que comemorávamos 50 anos da televisão, um dos maiores veículos de comunicação do Brasil. Engrama também é um veículo de comunicação, com a diferença de que é feita por leigos que, aos poucos, estão aprendendo a produzir informação. Não pretendemos impor visão de mundo. Queremos incluir nosso ponto de vista sobre assuntos nem sempre abordados pela mídia e que são tão necessários para compreender melhor o novo conceito de velhice que adotamos para as nossas vidas.

ANDRADE, 2001:113

De 1998 até 2001, desenvolvemos a mesma proposta de produção coletiva de comunicação que vínhamos realizando com crianças, adolescentes e adultos, desta vez, com alunos acima de 45 anos, durante as aulas da Disciplina Multimeios, do curso da UNATI - Universidade Aberta à Terceira Idade da FITO/FEAO - Osasco/SP, sob coordenação de Mariúza Pelloso Lima.

Do trabalho com cerca de 120 alunos de diferentes turmas resultou a criação coletiva da Revista ENGRAMA e também do Programa de rádio Embalos de domingo à tarde.

Inicialmente reproduzida em fotocópias, circulando somente na faculdade e entre familiares, as três últimas edições da revista são impressas em gráfica, 
com uma tiragem de mil exemplares, distribuídas gratuitamente entre colegas, familiares, professores, anunciantes, estudiosos de gerontologia e comunicação social. ${ }^{39}$

Já o programa de rádio resultou do trabalho de um semestre letivo. Preparado em aula, durante a semana, era veiculado, aos domingos, na Guadalupe FM, emissora comunitária do bairro de Quitaúna, Osasco/SP, totalizando 25 horas de apresentação ao vivo. ${ }^{40}$

Em se tratando de proposta educacional voltada para pessoas da terceira idade, observamos que, ao se apropriarem de diferentes linguagens e tecnologias, ao mesmo tempo em que passam a usá-las a favor de si mesmos, tornam-se mais seguros, mais altivos, fortalecidos. Adotam para si mesmas outra concepção de velhice, bem definida pela aluna Odete, para quem essa nova etapa da existência significa "seguimento de vida", ou seja, a certeza de que "continuam vivos, capazes de criar, e de sentir prazer". (LOPES LIMA, 2001:3)

\section{Educação Formal}

A partir do ano 2000, o GENS passa a ser contratado por Secretarias de Educação para implantar projetos de Educomunicação para o Ensino Fundamental em escolas públicas dos municípios paulistas de Vargem Grande Paulista (2000 a 2001), Sorocaba (2001 a 2004), Piedade (2002), Alumínio (2003) e Atibaia (2006 a 2007).

$\mathrm{Na}$ base da proposta, assenta-se a intenção de que a comunicação faça parte dos conteúdos curriculares e as produções coletivas dos alunos sejam consideradas como atividade de sala de aula, posto que, por excelência, são

\footnotetext{
${ }^{39}$ Capas, editoriais e dois artigos de alunas dessa revista encontram-se disponíveis no DVD, em anexo.

${ }^{40}$ Também disponível no DVD, em anexo, um trecho de um desses programas.
} 
interdisciplinares e contemplam aos pressupostos das diversas áreas de conhecimento apresentadas nos Parâmetros Curriculares Nacionais.

Como forma de traduzir esses objetivos, idealizamos um planejamento que reuniu Supervisores, Gestores, Coordenadores Pedagógicos e Professores de Escolas Públicas de Ensino Fundamental do Estado de São Paulo de forma a permitir pela vivência de todo processo de produção coletiva de comunicação, a compreensão dos conteúdos escolares envolvidos nas ações de Educomunicação. ${ }^{41}$

No ano de 2001, a convite do coordenador do NCE-ECA/USP, Prof. Dr. Ismar de Oliveira Soares, fomos convidados a compor a equipe idealizadora do Projeto Educomunicação pelas ondas do rádio ${ }^{42}$. Coube-nos a tarefa de idealizar as atividades de produção radiofônica, ora realizadas exclusivamente pelos estudantes, ora por estes junto com professores e membros da comunidade escolar das 465 escolas municipais de Ensino Fundamental do Município de São Paulo, bem como a de produzir materiais de orientação para a formação da equipe do NCE. ${ }^{43}$

Essas iniciativas inauguraram um novo momento na história dos recursos tecnológicos aplicados à educação, para além do uso do computador. O ensino formal passa a interessar-se por tecnologias de comunicação como potenciais instrumentos que, tanto quanto o lápis e a caneta, já reconhecidos e incorporados nas práticas pedagógicas, podem também documentar processos de criação.

\footnotetext{
${ }^{41}$ Muitos desses materiais estão disponíveis em http://www.portalgens.com.br

${ }^{42}$ Em 28 de dezembro de 2004, o Programa EDUCOM - Educomunicação pelas ondas do rádio é instituído no Município de São Paulo pela Lei no 13.941.

${ }^{43}$ No DVD se encontra uma das orientações para a equipe de articuladores e monitores, responsáveis pelas atividades realizadas com os cursistas, nos pólos de formação.
} 
A escola faz parte do mundo e para cumprir sua função de contribuir para a formação de indivíduos que possam exercer plenamente sua cidadania, participando dos processos de transformação e construção da realidade, deve estar aberta e incorporar novos hábitos, comportamentos, percepções e demandas.

Ao mesmo tempo em que é fundamental que a instituição escolar integre a cultura tecnológica extra-escolar dos alunos e professores ao seu cotidiano, é necessário desenvolver nos alunos habilidades para utilizar os instrumentos de sua cultura.

Parâmetros Curriculares Nacionais para o Ensino Fundamental, 1998: 138

Nesse sentido, tais programas se configuram como propostas de uso da linguagem oral com eficácia, sabendo adequá-la a intenções e situações comunicativas que requeiram conversar num grupo, expressar sentimentos e opiniões, defender pontos de vista, relatar acontecimentos, expor sobre temas estudados, de modo a participarem de diferentes situações de comunicação oral, acolhendo e considerando as opiniões alheias e respeitando os diferentes modos de falar (Parâmetros Curriculares Nacionais de Língua Portuguesa para o Ensino Fundamental, 1998:113).

\section{Cultura}

\section{Produção de vídeo}

História e memória são construções e ocorrem num campo de disputas. 
Convencidos de que produzir comunicação é um direito, o GENS, valendo-se da mesma metodologia, desenvolveu oficinas de vídeo durante a $1^{\underline{a}}$ e $2^{\underline{a}}$ Mostra Paraty de Cinema Nacional (2003 e 2004) e o $2^{\circ}$ Festival de Cinema de Paraty - Paratycine (2005) para moradores de Paraty / RJ, considerada a "cidade-cenário" de grandes filmes. Na mesma tela que nos demais dias da Mostra eram exibidos filmes de consagrados diretores do cinema nacional, os participantes das oficinas puderam mostrar as produções realizadas durante os eventos. ${ }^{44}$

Saber, enfim, que "... uma das preocupações dos indivíduos e grupos que dominam as sociedades é de tornarem-se também donos das lembranças e dos esquecimentos" (Le GOFF, apud BERGAMASCHI, 1996:3), nos mobiliza a querer continuar oferecendo oportunidades para que mais e mais pessoas, diante das telas, se projetem como autoras de suas próprias histórias, fictícias ou não, e se reconheçam como dotadas da capacidade de elas próprias documentarem o que julgarem importante sobre si mesmas.

\section{Produção radiofônica com comunidades tradicionais}

Um povo que não ama e preserva suas formas de expressão mais autênticas, jamais será um povo livre.

Plínio Marcos ${ }^{45}$

\footnotetext{
${ }^{44}$ Duas dessas criações estão disponíveis no DVD, em anexo, e as demais em http://www.portalgens.com.br/paraty

${ }^{45}$ Dramaturgo brasileiro, jornalista, camelô de seus próprios livros (1939-1999), para quem "O que pode te tirar de uma sociedade capitalista baseada nos princípios de propriedade privada dos bens sociais, portanto na ânsia possessiva do lucro, portanto, na competição e na violência, é o autoconhecimento, é a religiosidade". Disponível em http://www.rodaviva.fapesp.br/materia/2/entrevistados/plinio marcos 1988.htm. Acesso em 19 de novembro de 2008.
} 
Atendendo convite de Plínio Melo, diretor da MONGUE - Proteção ao Sistema costeiro, em 2004, o Cala-boca já morreu promove uma oficina de rádio, durante o Seminário $O$ que aprendi com meus pais, evento de lançamento do Projeto Viola Peregrina ${ }^{46}$, cujo objetivo consistiu em registrar as produções musicais de comunidades da Estação Ecológica Juréia-Itatins EEJI (SP) e seu entorno, local que abriga um acervo de importantes manifestações culturais tradicionais (melodias, ritmos e letras, assim como danças) inseridas em suas práticas festivas ou religiosas.

Eu espero que dê tudo certinho, porque é bonito, né? A gente mora aqui neste lugar difícil. A gente tá aqui com um restinho de tradição. (...) Então, tem que gravar, e tudo. Isso é importante.

(depoimento apud MELLO, 2000:39)

\section{Educação Ambiental}

Em 2005, a ONG Projeto Cala-boca já morreu, como uma das organizações parceiras do II Encontro da Juventude pelo Meio Ambiente, em 2005, assume a formação em Educomunicação do Programa Juventude e Meio Ambiente, ação interministerial do Ministério da Educação e do Ministério do Meio Ambiente. No total, 150 jovens, entre 15 e 29 anos, vivenciam algumas possibilidades de a produção coletiva de rádio contribuir para o fortalecimento dos CJ - Coletivos Jovens de Meio Ambiente de todos os estados brasileiros e da Rede da Juventude pelo Meio Ambiente - REJUMA ${ }^{47}$.

${ }^{46}$ O Projeto Viola Peregrina encontra-se disponível no site http://www.mongue.org.br/violaperegrina/viola.htm Acesso em 10 de maio de 2008.

${ }^{47}$ A REJUMA teve seu início no Encontro Nacional da Juventude Pelo Meio Ambiente, realizado em setembro de 2003 em Luziânia-GO, por iniciativa dos Ministérios do Meio Ambiente e da Educação, paralela ao desenvolvimento do programa Vamos Cuidar do Brasil, que reuniu os então chamados Conselhos Jovens de Meio Ambiente, criados em todos os estados para a mobilização, organização e articulação para a I Conferência Nacional de Meio Ambiente e a Conferência Nacional Infanto-Juvenil Pelo Meio Ambiente. Dela participam jovens de 16 a 25 anos, que atuam em diversos setores da 
Igualmente, nos anos de 2003 e 2005, desenvolve, na mesma perspectiva e procedimento, oficina de rádio com 260 delegados de 11 a 14 anos, alunos de escolas do Ensino Fundamental de $5^{\mathrm{a}}$ a $8^{\mathrm{a}}$, de comunidades nos assentamentos rurais, comunidades quilombolas, comunidades indígenas e movimento nacional de meninos e meninas de rua, durante a I e II Conferências Nacionais Infanto-Juvenil pelo Meio Ambiente - MEC e MMA ${ }^{48}$.

No lugar do senso comum instaurado pelas grandes redes de comunicação, que, em geral, buscam padronizar nossas idéias e sentimentos, podemos dizer que começamos a ter acesso a outras abordagens dos acontecimentos, sob diferentes pontos de vista.

As produções já realizadas nos mostram adolescentes e jovens brasileiros que começaram a entender que a palavra é fruto de construção.

É dessa compreensão e da nossa escrita dela que podemos produzir alguma coisa que seja da nossa autoria. Nesse sentido, pesquisar e entender o meio ambiente, produzir conhecimento sobre ele e divulgá-lo é a colaboração que a educomunicação oferece a cada um de nós, para que sejamos autores da nossa história. Afinal, o que é ser autor se não o escritor de suas próprias palavras, o sujeito de seu discurso?

(LOPES LIMA e MELO, 2008: 173)

sociedade (ONGs, Poder Público, Partidos Políticos, Redes de Juventude, Movimentos Juvenis etc) Funciona através de uma lista de discussão (juventudepelomeioambiente@googlegroups.com). Disponível em www.rejuma.org.br. Acesso em 15 de dezembro de 2008.

${ }^{48}$ A Conferência Nacional Infanto-Juvenil pelo Meio Ambiente, realização do Órgão Gestor da Política Nacional de Educação Ambiental, por meio dos Ministérios da Educação e do Meio Ambiente, é um processo de mobilização para a formação de comunidades sustentáveis. É a segunda edição da proposta que em 2003 reuniu mais de cinco milhões de brasileiros em torno da idéia: Cuidar do Brasil. Disponível em http://www.conferenciainfantojuvenil.com.br/index.php?pagina=conferencia.php Acesso em 15 de dezembro de 2008. 


\section{Formação inicial de professores}

Atendendo ao proposto nos PCNs - Parâmetros Curriculares Nacionais, especialmente de Língua Portuguesa, que apontam as práticas sociais como norteadoras das atividades que devem ser desenvolvidas na escola para que o aluno domine a língua oral e escrita nas instâncias privadas e públicas, a Faculdade Sumaré - São Paulo/SP, incluiu na grade curricular do Curso de Pedagogia, a disciplina Tecnologia Educacional l, bem como produção de programa de rádio e elaboração de jornal impresso, no Plano Pedagógico de Língua Portuguesa. ${ }^{49}$

Assim, estamos contribuindo para que os futuros professores entendam a importância da comunicação social na formação das pessoas, bem como aprendam, de forma teórico-prática (ou vivencial) os pressupostos que fundamentam a produção coletiva de comunicação, na perspectiva da Educomunicação. ${ }^{50}$

Nessa direção é oportuno retomar Mário Kaplún, para quem a 'Comunicação Educativa' existe para dar à Educação métodos e procedimentos para formar a competência comunicativa do educando. Não se trata, pois, de educar usando o instrumento da comunicação, mas que este se converta no eixo vertebrador dos processos educativos: educar pela comunicação e não para a comunicação.

(SOARES, 1999:55 )

\footnotetext{
${ }^{49}$ Os PPD - Plano Pedagógico-Didático das duas disciplinas encontram-se no DVD, em anexo.

${ }^{50}$ Algumas dessas produções estão disponíveis em http://faculdadesumare.podomatic.com/ Acesso em 5 de junho de 2008.
} 


\section{Detalhamento $^{51}$ da metodologia Cala-boca já morreu}

Nas últimas décadas, manifestações ocorridas na sociedade civil vêm revelando a existência de uma comunicação diferenciada: as pessoas, ao participarem de organizações e movimentos comprometidos com a solução dos grandes problemas sociais, acabam inseridas num processo de educação não formal relacionado diretamente a propostas populares de formação para a cidadania. Nesse sentido, estaríamos diante de um fenômeno novo, mobilizador; com exigências teórico-metodológicas que nem sempre contam do ideário ou das práticas previstas para o ensino formal.

SOARES, 2007: 4

De início, queremos esclarecer que o que segue não tem pretensão alguma de servir de modelo de como produzir comunicação na perspectiva da Educomunicação. Muito longe disso. Seria incoerente com o que pretendemos através dela. O que buscamos, sim, é tornar evidentes nossos compromissos com uma educação que se vale dos meios de comunicação para o desencadeamento de processos de autoria - condição para a constituição de sujeitos autônomos, e também com a comunicação comunitária, como forma de negação radical ao controle oligopolizado dos meios de comunicação no Brasil.

E por que chamar de metodologia, então? Talvez porque "estilo", "atitude" ou "postura", palavras que melhor traduzem o que fazemos, causem estranhamento, desviando a atenção de questões importantes, como estas: que produzir comunicação é direito humano a ser exercido por todas as pessoas; que as tecnologias e linguagens midiáticas podem ser utilizadas como instrumentos que possibilitam aos envolvidos no processo de criação reconhecerem-se nas próprias

\footnotetext{
${ }^{51}$ Tomamos aqui o sentido latino do termo, derivado do antepositivo talh-, talèa, ae 'chantão ou tanchão, significando o ramo que se finca na terra para criar raízes e formar uma nova árvore. Ou seja: uma vez plantado o ramo, inaugura-se a imprevisibilidade da árvore. O tamanho da sua raiz, do tronco e da copa, o viço das folhas, o lado para onde vai se inclinar, quanto tempo ela vai viver não depende apenas de um elemento.
} 
palavras e imagens que produzem; que do exercício de envolvimento consigo e com o outro, é possível resignificarem suas histórias pessoais e coletivas.

A metodologia em questão nasce no Brasil, num momento em que a comunicação comunitária dava mostras de que ela poderia contribuir para a formação de gente que, ao falar pelo rádio, aprendesse a se responsabilizar pela própria palavra, que estando em sintonia consigo, por conseqüência, conseguisse ouvir de fato o outro e com ele aprendesse a cuidar mais de seus sonhos, necessidades e projetos. Era o começo de um tempo cheio de esperança, muito diferente de épocas anteriores.

Não à-toa, uma constatação das possibilidades reais desse novo tempo nascia como fruto da observação do que um bando ${ }^{52}$ de dez crianças fazia com a palavra, quando ocupava espaços de comunicação, por onde antes só transitavam adultos que se consideravam especialistas, formados ou não, no assunto.

Mas, por que tamanho maravilhamento com uma experiência aparentemente tão simples, vivida com seres tão pequenos? E por que chamar de Cala-boca já morreu o modo de produzir comunicação concebido com esse bando? Por fim, por que estender esse mesmo nome a todas as demais produções de comunicação que doravante passaríamos a desenvolver com vários outros grupos?

Para responder a estas questões, é preciso destacar aqui alguns aspectos da Educação e da Comunicação que, do nosso ponto de vista, contribuíram para a nossa formação como povo.

Vamos, inicialmente, tomar o termo Educação como um conjunto de mecanismos, institucionais ou não, que exercem influência sobre o nosso modo de pensar e lidar com a vida, conosco e com os outros, e recuperar algumas de suas conseqüências sobre a formação do povo brasileiro. Essas ações, porque transmitiram valores específicos de um determinado grupo de pessoas, num determinado tempo, muito contribuíram para configurar o tipo de sociedade em que vivemos.

\footnotetext{
52 Estamos nos referindo às crianças participantes do Projeto Cala-boca já morreu, a quem atribuímos o significado de bando como sinônimo de "aves, especialmente fora do período reprodutivo, que permite melhorar o desempenho individual na procura de alimento e na segurança contra os predadores". (Houaiss)
} 
Assim sendo, não é possível esquecer os efeitos de mais de três séculos de escravidão, dos variados tipos de relações sociais essencialmente marcadas pelo clientelismo, bem como dos anos em que ditadores se revezaram no poder. Esses períodos todos, marcados por castigos físicos hediondos e outros tipos de punições aviltantes que causaram dores, muitas vezes mais agudas do que as sentidas no corpo, funcionaram como forma eficiente de ensinar à maioria a submissão através do medo:

Provisoriamente não cantaremos o amor, que se refugiou mais abaixo dos subterrâneos. Cantaremos o medo, que esteriliza os abraços, não cantaremos o ódio porque esse não existe, existe apenas o medo, nosso pai e nosso companheiro, o medo grande dos sertões, dos mares, dos desertos, o medo dos soldados, o medo das mães, o medo das igrejas, cantaremos o medo dos ditadores, o medo dos democratas, cantaremos o medo da morte e o medo de depois da morte, depois morreremos de medo e sobre nossos túmulos nascerão flores amarelas e medrosas.

Carlos Drummond de Andrade, 1940

Esse modelo cruel e desumano de pensar e de agir, do nosso ponto de vista, explica, em grande medida, por exemplo, porque fomos durante tanto tempo - em que pesem os movimentos de resistência que sempre existiram - um povo que soube tão bem agüentar, silenciar, consentir... Explica também por que nas relações que estabelecemos nos é tão fácil, em maior ou menor escala, causar sofrimento nos outros e abusar do poder. 
Sustentados por uma sólida pedagogia tradicional e tecnicista, valores como esses nos foram repassados também pela Educação formal. Na escola, muito se ensinou a obediência e a infração. Aprender a andar em fila, atender ao sinal, sentar um atrás do outro - sinônimos de ordem e de educação - para boa parte dos professores, nos levaram a associar respeito à obediência de comando; olhar a nuca, ao invés dos olhos nos ensinou a não conversar com os companheiros sobre nossa vida em comum. Calar para ouvir e aceitar toda espécie de autoridade, provar conhecimento repetindo palavras dos outros, tirar boas notas para ser motivo de orgulho para a família, ou por medo de ficar de castigo ou apanhar, promoveu a aprendizagem da competição, consequentemente, da mentira, da violação de regras.

A par da instituição escolar, um outro aparato, sem finalidades educativas explícitas, igualmente contribuiu para que esses traços culturais e ideológicos fossem incorporados às nossas ações cotidianas. Se antes, os colonizadores a serviço do rei, ao se aproximarem e nos seduzirem com espelhinhos, nos assustaram com demônios e caldeirão do inferno, interferiram em nossas crenças e, consequentemente em nosso comportamento, o equivalente tenta nos fazer a mídia.

Aos poucos os meios de comunicação foram fazendo com que boa parte de nós crêssemos em outros tipos de "deuses", já não mais divinos, mas ídolos, igualmente frutos da criação humana, "modelos de identificação: assim como o santo representa para a comunidade religiosa um modelo de virtude". (SODRÉ, 1981:150)

Comparando-se a eles, um sem-número de pessoas sente-se inferiorizada e passa a copiá-los, a reproduzir, mesmo que grosseiramente, seus gestos, seu vocabulário, e, principalmente suas roupas e idéias.

Se, contudo, nas relações vividas na instituição escolar e familiar a expressão "calaboca ${ }^{53 ،, ~ t a ̃ o ~ c o m u m e n t e ~ u s a d a ~ q u a n d o ~ s a ̃ o ~ c o n t r a r i a d a s ~ v o n t a d e s ~ e ~ o r d e n s ~}$ arbitrariamente estabelecidas soa aos gritos, garantindo seu entendimento imediato, o mesmo não acontece quando nos relacionamos com os meios de comunicação

\footnotetext{
${ }^{53} \mathrm{O}$ dicionário Houaiss registra duas acepções regionalistas para essa expressão: a primeira delas significando "suborno, dinheiro, compensação que se dá para calar a boca de alguém, para impedir reclamações, denúncias, demonstrações de insatisfação etc.; cala-boca" e a outra, usada em Minas Gerais, como sinônimo de "cacete grosso e de pequeno tamanho", alusão a "pedaço de madeira resistente, mais ou menos cilíndrico, de comprimento não muito grande, geralmente mais grosso numa das pontas, e usado especialmente para desferir pancadas"
} 
que, apesar de serem bens públicos e devessem obedecer a critérios legais de concessão de uso, são utilizados para fins privados ${ }^{54}$, à revelia da Constituição Nacional. Nesse setor, o "cala-boca" age de forma velada, tácita. Enquanto permanecemos "boquiabertos" diante deles,

(...) as emissoras as utilizam (as concessões) para promover a criminalização dos movimentos sociais e impor uma agenda política que Ihes interessa. Também é comum a discriminação contra mulheres, negros, indígenas, homossexuais, pessoas com deficiência e idosos, além de determinadas religiões e classes sociais. Estipulam padrões estéticos, éticos e morais, impondo valores que promovem e perpetuam preconceitos.

(INTERVOZES, 2007:2)

O encantamento diante do referido bando de crianças que deu origem à metodologia Cala-boca já morreu, pois, vem daí: do reconhecimento do potencial da comunicação comunitária. Pautada pelo uso da palavra como exercício do pensamento, a partir da aprendizagem da escuta não só de vozes dos outros, mas principalmente das nossas próprias, ela pode nos levar a reconhecer o papel que desempenhamos nas diferentes esferas sociais que explica a "engrenagem" do tipo de vida que mantemos.

"Cala-boca já morreu" representa, pois, a esperança de que mais e mais pessoas, tal qual aquele pequeno grupo de crianças, também tenha assegurado o direito humano de produzir comunicação, independente de idade ${ }^{55}$, etnia, gênero, condição sócio-econômica. E que, em assim sendo, contribuam para a afirmação da liberdade e a negação radical de toda forma de dominação e exploração.

\footnotetext{
${ }^{54}$ Tratamos sobre como funciona o sistema de outorga dos meios de comunicação no Brasil no capítulo I.

${ }^{55} \mathrm{O}$ artigo $13^{\circ}$, da Convenção sobre os direitos da criança afirma "A criança tem direito à liberdade de expressão. Este direito compreende a liberdade de procurar, receber e expandir informações e idéias de toda a espécie, sem considerações de fronteiras, sob forma oral, escrita, impressa ou artística ou por qualquer outro meio à escolha da criança."
} 
Nesse sentido, a produção coletiva de comunicação, na perspectiva da Educomunicação, concebida como sinônimo de Educação pelos Meios de Comunicação, ultrapassa o sentido instrumental da educação e

(...) como fim em si mesma valoriza o conhecimento de si mesmo através do conhecimento do mundo e, neste sentido, necessita de nossos conhecimentos, informações e, sobretudo, de nossa interlocução, para auxiliá-la na autoconstrução de sua própria pessoa. As decisões sobre sua inserção e engajamento profissional, social, político, cultural, etc. são decisões íntimas e intransferíveis da própria pessoa.

(FERREIRA SANTOS, 2004: 34) 


\title{
Movimentos da metodologia Cala-boca já morreu ${ }^{56}$
}

\author{
(...) Somente o diálogo, que implica um pensar crítico, é capaz, \\ também de gerá-lo. Sem ele não há comunicação e sem esta \\ não há verdadeira educação.
}

FREIRE, 1992:83

Observamos que nem todos os grupos iniciam seus trabalhos de produção coletiva de comunicação da mesma maneira. Entre crianças é comum a atividade ser desencadeada a partir de expressões como "eu quero ser repórter", ou "vamos fazer um 'filme de terror'?", o que leva o grupo a pensar em assuntos ou argumentos que melhor sirvam para realizar esses desejos.

Públicos de outras idades começam, às vezes, conversando sobre o tratamento ou a forma que dariam a um assunto que viram ou ouviram recentemente na mídia. Outros iniciam avaliando o trabalho anterior do próprio grupo, antes de pensarem na nova criação.

Por esse motivo, as descrições que seguem nomeiam os movimentos realizados pelos grupos envolvidos com produção coletiva de comunicação, não devendo ser confundidas com normas para serem seguidas, obrigatoriamente, na ordem em que aqui aparecem.

\footnotetext{
${ }^{56}$ Também nomeada por nós, durante os anos de 2000 a 2003, como Metodologia das Quatro Etapas (ver orientações para a equipe do Projeto educom.rádio, no DVD)
} 


\section{Levantamento e definição da pauta}

Tudo o que eu não invento é falso

Manoel de Barros, $2006^{57}$

Questões como centralização do poder, ou seja, existência de um mentor intelectual determinando as tarefas de seus subalternos, produção determinada pelo preço da encomenda ou para atender regras estabelecidas por patrocinador, encontram-se embutidas nesta etapa.

O levantamento e a definição da pauta é o momento em que cabe ao grupo, formado por crianças, usuários da saúde mental, professores, idosos ou jovens não importa - decidir com total liberdade sobre o que quer tornar público. Disponibilidade para a escuta e capacidade argumentativa constituem a tônica desse momento da criação coletiva.

Quando isso acontece, observamos que, independente da idade dos integrantes, sempre alguém se auto-convoca para desencadear a partir da pergunta "Sobre o que a gente vai falar?", uma acirrada discussão, entremeada de vozes inflamadas e silêncios que incomodam.

Compreensível, afinal aprender a pensar e decidir por si mesmo (ou "pela própria cabeça", como sabiamente o povo diz) não é uma tarefa das mais simples. Não falta quem nessa hora sinta e demonstre insegurança, pedindo que o mediador dê uma idéia ou, que pelo menos, diga se o que estão planejando "está certo, se é assim mesmo".

Uns permanecem quietos, não opinam mesmo que instigados; outros, impacientes e afoitos, vão tentando desde o princípio impor sua opinião, alegando que o "o tempo está passando" e que se vacilarem não conseguirão terminar o que precisam, muito lembrando as comparações de George Woodcock sobre a sociedade ocidental e as sociedades mais antigas da Europa e do oriente que

\footnotetext{
${ }^{57}$ Epígrafe de Memórias Inventadas. A segunda Infância
} 
(...) se transformaram em relógios, a repetir sempre as mesmas ações com uma regularidade em que nada se parecia ao ritmo natural da vida. Tornaram-se, para usar uma expressão vitoriana, "tão regulares quanto os ponteiros de um relógio"

(WOODCOCK, 1977:120)

Não raro, habituados que fomos a decidir somente por contagem de votos, o grupo encurta a discussão e parte para uma outra etapa do trabalho. Sugerimos, nesse caso, que haja, ao menos, a possibilidade de se abster de votar e que estes, além de abertos, possam ser justificados, de modo que essa simples ação sirva para que os participantes do grupo se conheçam melhor e, de fato, vivenciem os efeitos de uma decisão efetivamente tomada pelo grupo.

\section{Produção}

Para não repetir, ingenuamente, nas produções coletivas de comunicação na perspectiva da Educomunicação procedimento semelhante ao de grandes empresas de comunicação, precisamos submeter à crítica alguns aspectos que caracterizam o processo de produção de mensagens nesses espaços. Um deles, retomando a análise sociológica de Bourdieu sobre como são "fabricadas" as notícias na televisão, diz respeito ao mecanismo estrutural que leva o jornalista a ser tanto manipulador quanto manipulável. Manipulador porque, ao aceitar, por exemplo, dar destaque a notícias de variedade ${ }^{58}$, impor tema e tempo para entrevistados, escolher imagens que não fazem "cair o queixo do burguês", nem "do povo", dentre outros mecanismos de controle da informação, contribui para transformar o que poderia ser "um extraordinário instrumento de democracia direta" em um "instrumento de opressão simbólica”. (BOURDIEU, 1997:22-26). Manipulável porque, com freqüência, é conivente com esse jogo, sem ter consciência de que

\footnotetext{
${ }^{58}$ Assim são chamadas pelo autor as notícias sensacionalistas em torno de temas genéricos ligados a sexo, crime ou dramas que não causam controvérsia e que, por distraírem o espectador, ocultam coisas que o capacitariam a exercer seus direitos como cidadão. (Bourdieu, 1997:23-24).
} 
profissionalmente sustenta e aprimora tal opressão. Além disso, porque se conforma às regras políticas e econômicas que definem o papel que lhe cabe nos meios de produção e divulgação de informação. A questão se relaciona à ética, portanto, e sobre esse aspecto que direcionamos o que segue.

Submeter-se ao comando de alguém, dependendo dele, inclusive para se manter na empresa, legitima a incapacidade intelectual de tomar decisões e, principalmente, de criar. Ser operador de idéias dos outros transforma, seja qual for a atividade, em ação burocrática, mecânica, que exige do corpo quase tão somente o exercício dos músculos. Não ser autor equivale a produzir comunicação como quem "fabrica" bens ou utilidades para satisfazer necessidades humanas.

Ora, reiteramos que as atividades na perspectiva da Educomunicação propõem-se a contribuir para a formação de indivíduos autônomos, capazes de se livrar de toda tentativa de dominação. Portanto, a proposta de que toda produção de comunicação seja coletiva não é aleatória. Trata-se de uma opção e isso precisa ser melhor entendido.

Quando realizamos em grupo determinada tarefa, as relações que estabelecemos podem nos permitir ver as atitudes que tomamos em relação uns aos outros refletidas no processo de sua realização. Essa relação intensa escancara, quer queiramos ou não, os conceitos que efetivamente sustentam a ação de cada um, tais como respeito, solidariedade, cooperação. Quando esse modo de produzir comunicação se transforma em objeto de nossas reflexões, acreditamos ser possível dar início a um novo modo de relacionamento social, onde o trabalho (consideremos assim toda produção de comunicação realizada) não contribui para fragilizar e alienar o homem de si mesmo. Antes: fornece elementos para que, analisando como o realizamos, entendamos o grau de dedicação que empenhamos nessa proposta que parte da auto-convocação e não do cumprimento de ordens.

Por esses motivos, propomos que os participantes dos grupos, independente do grau de instrução, de origem, gênero, nível cultural e faixa etária de seus integrantes tenham assegurado o direito de opinar em todas as etapas da atividade e mesmo realizar qualquer uma das funções necessárias para a produção de uma mensagem. 
Nesta etapa da metodologia, portanto, o grupo dá forma concreta às idéias coletivamente escolhidas para as produções: decide gênero e formato mais conveniente para a proposta, define a duração da produção, divide tarefas de acordo com as necessidades, entre outros itens.

Desse exercício sistemático de observar com rigor as questões inter-pessoais que vêm à tona quando coletivamente realizamos uma tarefa, podem surgir, inclusive, alterações no tratamento técnico das mensagens. Assim foi que a pré-edição passou a fazer parte da etapa de produção descrita nesta metodologia.

As considerações de um grupo de professoras integrantes da formação para a criação coletiva de vídeo, durante a $1^{\text {a }}$ fase de implantação do Programa de Educomunicação de Sorocaba/SP, em 2001, desencadearam na equipe do GENS várias reflexões que nos levaram a reestruturar o modo de ensinar.

Constatamos, inicialmente, que elas não encontravam tempo para "decupar" as fitas das gravações que conosco realizavam, semanalmente, em meio às tantas tarefas escolares. Era muito difícil, senão impossível para elas, fazer levantamento minucioso das imagens e dos sons gravados, indicando a posição e o tempo de duração de cada trecho, para servir de referência ao trabalho que ainda teriam pela frente: o de edição de suas produções. Ou seja, essa sequência: definir tema, roteirizar, colher imagens, decupar, editar, para só depois concluir o trabalho, dava mostras suficientes de que era ineficaz.

Observando a reação daquelas professoras, e nos dispondo a mudar o que fosse preciso para recuperar o ânimo delas pela criação e, assim, contribuir para que a produção de vídeo fosse incorporada ao cotidiano da escola, sem o peso de "um fardo", nos levou a retirar a fase de decupagem das imagens e substituí-la pelo que passamos a chamar de pré-edição.

Das reflexões sobre a prática, inicialmente voltadas para a produção de imagem, revimos conceitos importantes que passaram a ser incorporados para as demais produções coletivas de comunicação. 


\section{Pré-edição}

(...) eu aprendera que as imagens pintadas com palavras eram para se ver de ouvir. (...) Arrisquei fazer isso na cega. Depois que meu avô me ensinou que eu pintara a imagem erótica da Manhã. Isso fora.

Manoel de Barros, 2006: Pintura III.

Corresponde ao momento em que cada um do grupo (e não apenas um especialista no assunto) se dedica a procurar com os olhos e ouvidos - órgãos diretamente responsáveis pela visão e audição, e com outros "equipamentos" responsáveis pela percepção, o que precisa para compor a criação coletiva.

"Nós no movemos entre formas", nos lembra Ostrower (1987: 9). Assim, a préedição é um tempo de silêncio dedicado ao exercício de aguçamento da observação sobre o que está em volta. É uma oportunidade para prestar mais atenção no tom das cores, nos efeitos de claro e escuro, nos detalhes da natureza, das pessoas, animais e objetos. É entrar em sintonia com o material que a própria vida nos dispõe para incitar a imaginação e a reflexão.

Essa atitude é similar ao de garimpeiro ${ }^{59}$, que com paciência e meticulosidade cavuca a terra em busca de preciosidades. Ou seja, um trabalho que precisa de ferramenta, mas que só com ela não se realiza. A qualidade do trabalho pressupõe intimidade entre o homem, a terra e a ferramenta.

O mesmo sentido se dá nas produções de comunicação. De nada adiantam a câmera e o gravador se eles não forem manuseados por quem sabe que esses equipamentos não são mais do que meios para expressar o que sentem e pensam sobre as coisas do mundo.

\footnotetext{
${ }^{59}$ llustra esse trabalho de garimpagem o vídeo-documentário Os bichos, realizado por um grupo de crianças entre 8 e 11 anos de idade, disponível em http://www.portalgens.com.br/videoescola/videos/wmv/doc0213.wmv.
} 
Passado esse momento de coleta de imagens e sons, o grupo ouve o significado de cada uma das sugestões e decide por aquelas que comporão a mensagem final.

$\mathrm{Na}$ sequência, com os recursos tecnológicos de que o grupo dispõe, a produção passa a ser gravada, já na ordem estabelecida, a começar, se quiser, pelo título da produção e demais elementos que julgarem convenientes, incluindo a ficha técnica ou "assinatura" dos criadores. Ao final da gravação, o produto está praticamente pronto, bastando apenas ser assistido para que o grupo decida pequenos acertos de finalização.

O momento em que assistem ao que produziram confirma, mais uma vez, a riqueza do processo. Não há grupo algum, inclusive o de meninos e meninas considerados os mais bagunceiros, que nesta hora não se aquiete e, num silêncio profundo não se embeveça do que ouve e vê. Porque se re-conhecem no que é projetado, se concentram e, demonstram alegria. Não à toa, nessas horas, ao término da exibição dizerem: Vamos ver de novo?

Do encantamento resulta a vontade de continuar a produzir, ou seja, de aperfeiçoar o ofício de artesão da própria criação.

\section{Apresentação}

Etapa em que os participantes tornam público a mensagem escrita, radiofônica ou audiovisual que juntos idealizaram. Independente de sua duração, esta fase confere à produção coletiva de comunicação, na perspectiva da Educomunicação, a dimensão da importância do outro na constituição de sujeitos autônomos. ${ }^{60}$

Toda exibição pública faz com que nos percebamos expostos integralmente. Por isso nosso organismo, nos mais variados graus, reage ao reconhecer a

\footnotetext{
${ }^{60}$ Disponível no DVD, em anexo, exemplo de grade de programação de uma Rádio-Escola, cujo horário de funcionamento não excede a 30 minutos, 15 no período da manhã e 15 , no período da tarde.
} 
singularidade desse momento: o coração acelera, a respiração descompassa, as mãos gelam, a barriga dói.

Apesar do desconforto, saber-se percebido nos leva a ficar mais centrados em nós mesmos. Passamos a cuidar do nosso discurso. Pensamos, antes de dizer. Fazemos uma seleção de palavras para melhor expressar as idéias e sentimentos que queremos transmitir. Num esforço de nos fazer entender, ensaiamos até, mesmo que mentalmente, a sequência das frases, a entonação, os gestos, pois queremos ser convincentes e nos mostrarmos competentes para o que nos dispusemos.

Essa vontade de realizar uma boa comunicação em meio à insegurança de não sabermos se vamos conseguir, em certa medida, explica porque às vezes, até imitemos modelos de sucesso já reconhecidos de escritores, apresentadores de rádio ou de televisão.

Se as etapas que antecedem a apresentação, contudo, forem intencionalmente voltadas para o entendimento do que se pretende com a produção coletiva de comunicação, maiores serão as possibilidades de transformarmos esse momento em uma oportunidade de aprendermos a valorizar o nosso próprio jeito de falar sobre o que nos interessa. Será a hora de não sentirmos vergonha do sotaque da nossa região, de usarmos expressões locais para melhor traduzirmos determinadas notícias, por exemplo, lembrando que

Ninguém comete erros ao falar a sua própria língua materna, assim como ninguém comete erros ao andar ou respirar. Só erra naquilo que é aprendido, naquilo que constitui um saber secundário, obtido por meio de treinamento, prática e memorização: erra-se ao tocar piano, erra-se ao dar um comando ao computador, erra-se ao falar/escrever em língua estrangeira. A língua materna não é um saber desse tipo: ela é adquirida pela criança desde o útero, é absorvida junto com o leite materno. Por isso qualquer criança entre os 4 e 5 anos de idade (se não menos) já domina plenamente a gramática de sua língua.

(BAGNO, 2008: 149) 
A apresentação, assim concebida - como um aprendizado de que a partir da aparição pública de cada indivíduo, todo um grupo social se fortalece, é de suma importância nesta metodologia. Porém, como já frisamos várias vezes, entre entender e incorporar essas convicções às ações há um longo processo a ser percorrido, pois não se muda a história de uma hora para outra. Para agir é preciso estar convencido. Por esse motivo, insistimos na necessidade de as crianças terem também garantido o direito de produzir comunicação e, tal qual outro público, apresentarem suas produções. O exercício constante de criar e de estabelecer diálogo com um receptor, com o tempo, faz visível a força de transformação que possui a palavra partilhada.

Sobre modos de realizar apresentação, cabem também algumas considerações que, por mais que já tenham sido feitas, nelas insistimos: antes de definir o que fazer, é fundamental ponderar sobre "por que" fazer deste ou daquele jeito. Apresentação gravada ou "ao vivo" podem ser excelentes de igual maneira, desde que sejam opções tomadas pelo grupo e não por alguém que por ele se julgue único responsável.

Gravações permitem ensaiar, ver e rever várias vezes o que vai sendo criado. De certo modo, esse procedimento de "voltar" a um mesmo ponto pode permitir ao grupo e a cada integrante em particular colocar-se no lugar do receptor da própria mensagem e contribuir para alterar o que for necessário para que a mensagem seja mais vigorosa e interessante. Colocar-se no lugar de um outro é um recurso que pode aguçar o entendimento de que comunicar é uma ação transitiva, ou seja, que significa querer estabelecer contato com alguém sobre algo que se julga importante.

Apresentações "ao vivo" se diferenciam substancialmente das gravadas. Como bem nos diz Marcos, o menino da Rádio LEAS, do documentário Processo: "ao vivo" dá um negócio que você nem imagina!.

Realmente é inimaginável o que os minutos desencadeiam naquele que se apresenta e, ciente da duração da apresentação, sabe que é preciso muita rapidez para escolher e organizar as palavras, para dizer o que precisa do jeito que gostaria; que sabe que seu possível nervoso ficará escancarado diante do público receptor; que dele dependem seus colegas para dar continuidade ao que planejarem. 
Em suma, "ao vivo" a relação com o tempo passa a ser muito mais intensa. Os segundos, às vezes, podem parecer séculos. Aprender a lidar com a insegurança, com o imprevisto, contudo, podem contribuir para o exercício da atenção concentrada, tão necessárias para uma boa comunicação.

A terceira maneira de promover apresentação é realizar Mostras que, diferente do que se convencionou chamar de festival, não promove competição, nem tampouco entrega prêmio para alguns de seus participantes, baseado no julgamento dos trabalhos por um corpo de especialistas.

Promover disputa não combina com quem sonha com uma sociedade pautada pela fraternidade. Eleger "melhores" coloca uns contra os outros, causa tristeza, frustração.

As Mostras pretendem recuperar o sentido original de festival, do latim festívus, festivo, alegre; onde há festa, divertimento'. Com palavras mais objetivas, elas estão comprometidas tão somente com a partilha, posto que se concebem como oportunidade para que todas as pessoas usufruam do direito previsto no artigo $\mathrm{V}$, inciso IX, da Constituição Brasileira que declara: é livre a expressão da atividade intelectual, artística, científica e de comunicação, independentemente de censura ou licença.

\section{Considerações sobre o processo e o produto}

Retiramos dessa etapa a palavra "avaliação", posto que seu objetivo não é atribuir valor, em forma de nota ou preço, ao produto de comunicação. Menos ainda, colocar sob julgamento de um ou mais avaliadores técnicos a qualidade do trabalho coletivo realizado.

O que pretendemos não se resume em verificar se o produto final atingiu determinado "público-alvo" ou detectar componentes técnicos que faltam para que isso aconteça. Fosse essa intenção, incluir na equipe um especialista qualificado, 
preferencialmente, formado pelos renomados cursos de comunicação que existem em nosso país, asseguraria o sucesso das produções.

Desejamos que o produto desencadeie no grupo uma leitura que permita a ele reconhecer como se deu o processo de produção de comunicação. Estamos nos referindo, mais uma vez, à necessidade de o grupo atentar com rigor às relações estabelecidas entre os seus integrantes para a realização da tarefa a que se dispôs.

Por isso é um momento que prescinde de especialistas e, caso eles componham o grupo (hipótese nunca descartada), que se coloquem no mesmo patamar de importância dos demais. Isso significa ter que abrir mão da vaidade e do status conferido por títulos e diplomas, pois muitas vezes estarão ao lado de gente que mal escreve o próprio nome. Ter que aceitar que elas participem em pé de igualdade nas grandes discussões sobre o rumo da comunicação é algo que exige um imenso esforço para quem está acostumado a fazer parte de grupos seletos de discussão.

Para esse tipo de exercício não basta somente compreensão teórica. É preciso muito mais: é necessário reconhecer que o outro também é um sujeito, cuja vivência o dota de saber, nem mais nem menos que o acadêmico, apenas diferente deste.

E, como não se trata de fazer apologia do senso comum, ou elogio panfletário ao menos favorecido, o mesmo empenho vale para o não-letrado (ou o menos letrado). Também ele é levado a se deslocar do lugar de quem não tem capacidade de entendimento mais elaborado da vida em sociedade, para o de um sujeito produtor de cultura e, portanto, co-responsável pela realidade.

Ou seja, esse modo de produção de comunicação pode constituir-se numa maneira de compreender as tramas das relações sociais presentes no cotidiano dos participantes da proposta. Por isso, afirmamos que, por mais bonito e bem feito que seja o produto, ele fica aquém da riqueza do processo, do percurso que levou o grupo a conseguir realizar o que se estampa no produto final.

$E$, assim é que a metodologia Cala-boca já morreu se concebe: como um modo de produzir comunicação que se junta ao sonho de João Cabral de Melo Neto de que uma "manhã" seja tecida, com a consciência de um galo que sabe que 
sozinho não tece uma manhã: ele precisará sempre de outros galos. de um outro galo que apanhe o grito que um galo antes e o lance a outro; e de outros galos que com muitos outros galos se cruzem os fios de sol de seus gritos de galo, para que a manhã, desde uma teia tênue, se vá tecendo, entre todos os galos. E se encorpando em tela, entre todos, se erguendo tenda, onde entrem todos, se entretendendo para todos, no toldo (a manhã) que plana livre de armação. A manhã, todo de um tecido tão aéreo que, tecido, se eleva por si: luz balão.

João Cabral de Melo Neto, 1966 


\section{O lado de dentro do}

\section{processo coletivo de produção de comunicação}

(...) a educação de sensibilidade perpassa as práticas iniciáticas à Cultura (mundo simbólico), através da cultura (no sentido agrário e hermesiano) das várias culturas (de grupos sociais num determinado espaço-tempo). Valendo-se das Artes (plásticas, musicais, literárias, videográficas e fílmicas) em que as imagens e os símbolos, articulados em narrativas, articulam, por sua vez, o repertório histórico-cultural do humano e sua memória com o repertório cultural cotidiano dos alunos e suas trajetórias individuais, tornando-os significativos, e possibilitando-Ihes a sua apropriação, perlaboração e reelaboração poiética. O conhecimento retorna, então, ao coração, cumprindo o seu destino.

FERREIRA, SANTOS, 2004: 53

Por inúmeras vezes afirmamos que, na perspectiva da Educomunicação, o processo de produção coletiva de comunicação é muito mais importante que o produto, por melhor que seja o seu acabamento do ponto de vista técnico. Como não se trata de um dado objetivo, mensurável, passível de ser provado, e sim de uma interpretação, configura-se como algo somente possível a quem testemunha a sua criação.

Por esse motivo buscamos para este capítulo imagens que nos conduzissem a um lócus de um ato criativo, para assistirmos ao que antecede o produto do trabalho humano, o momento em que se dá existência ao que antes ainda não existia. 
Escolhemos um vídeo chamado Processo ${ }^{61}$, realizado pelo GENS, sob os cuidados especiais de Diogo Noventa, para tornar perceptível aos que nos acompanharem os movimentos desse algo que nasce.

A câmera na mão, colocada na mesma altura das crianças que nele aparecem elaborando um pequeno programa de rádio, nos dará a sensação de estarmos junto com o grupo, sentados em torno da mesma mesa, sentindo os mesmos cheiros, o mesmo calor, ouvindo os mesmos sons. A posição parcial, circunscrita aos ângulos determinados por esse "estar dentro" de cada cena já declara (ou enfatiza), de antemão, aos que nos acompanharem o caráter perspectivo ou subjetivo da leitura que faremos dos signos e das formas sucessivas de sua representação.

Com imagens é possível compor um texto que ultrapassa as noções de verdade ou mentira, próprias do raciocínio binário (ou pensamento sem imagem, como nos diz Gilbert Durand), instaurado no ocidente, a partir de Aristóteles, no século 4 aC.

O imaginário abandona os extremos "ou isto ou aquilo" e dá lugar ao pensamento simbólico, ou "razão sensível", advinda da percepção. Em vez da lógica, a "alógica" da convivência dos contrários, quer nas manifestações dos mitos, dos sonhos, ou das narrativas da imaginação (DURAND, 2001).

Em se tratando de um vídeo, imagens em constante movimento, o que conseguiremos é acessar uma "rede complexa de incertezas, de trocas e evasivas" (FOUCAULT, 1985) ou o "excedente de significados que constitui a polissemia polifônica" fruto da ambiência de relações humanas praticadas (FERREIRA SANTOS, 2004)

Nesse sentido, para os interessados nos estudos de Educomunicação, a Educação de Sensibilidade (que não restringe o conhecimento à palavra impressa) pode contribuir para reforçar a necessidade de a comunicação ser entendida no âmbito da cultura de cada grupo humano. É aí, no esforço de compreensão da comunicação cultivada na intersubjetividade dos grupos, que se depreendem os fundamentos da educação que passam de uma geração para outra.

${ }^{61} \mathrm{O}$ vídeo, corresponde ao episódio 4 de uma série de 5 documentários sobre o Programa de Educomunicação de Sorocaba, encontra-se no DVD que acompanha esta tese e também se encontra disponível em http://www.portalgens.com.br/video-escola/videosDOC2/../../videos/alta/05.wmv 
Este capítulo se apresenta, pois, como um modesto esforço desse exercício de leitura.

Buscamos nas imagens videográficas captadas no estúdio da Rádio LEAS ${ }^{62}$, da Escola Municipal Professora Lea Edy Alonso Saliba, localizada no Jardim Marcelo Augusto, noroeste do Município de Sorocaba, o material de que precisamos para expressar um pouco da riqueza do processo de produção coletiva de comunicação, na perspectiva da Educomunicação.

O contexto da gravação se insere na proposta de implantação do Programa de Educomunicação de Sorocaba, através da Secretaria Municipal de Educação para a sua rede de ensino formada por 33 escolas municipais, durante o período de 2001 a 2004, sob responsabilidade do GENS - Serviços Educacionais.

Para que isso fosse possível, realizamos um trabalho de formação de estudantes do $1^{\circ}$ ao $9^{\circ}$ ano do Ensino Fundamental, professores, Coordenadores Pedagógicos, Gestores, Supervisores de Ensino e membros da comunidade escolar, como inspetores, assistentes administrativos e familiares.

Posteriormente, durante o período de assessoria às unidades escolares, pudemos constatar que a cada uma delas o Projeto se adaptava de acordo com o que queriam e conseguiam seus responsáveis.

O vídeo em questão documenta como um grupo específico de educadores dele se apropria e como se organiza para colocar em ação uma proposta de inclusão da comunicação no espaço escolar.

Estamos nos propondo a ver com mais vagar os meandros, todos tão parecidos com quem os que dele se ocupam. Inspirados pela sensibilidade poética de Manoel de Barros, habituado a olhar os meninos e os bichos nas suas horas mais travessas, nos dizendo, por exemplo, que Definitivo e cabal nunca há de ser o Rio Taquari. Cheio de furos pelos lados, torneiral - ele derrama e destramela à toa(...), (BARROS, 1997) outras duas imagens nos vieram à recordação antes de começar a escrever sobre as imagens do vídeo. A primeira atualiza o que uma senhora de 79

\footnotetext{
${ }^{62}$ Abreviatura de Lea Edy Alonso Saliba.
} 
anos, ainda hoje diz sempre que pendura roupa no varal "a gente tem que chacoalhar muitas vezes pra não ficar toda amassada e pendurar pelo avesso pra não descorar." A segunda presentifica o que antigas mulheres nos diziam quando éramos criança: "não é o lado direito do bordado e da costura que mostra se o trabalho está bem feito: é o avesso."

Pois bem: o cuidado com a roupa ${ }^{63}$ no trabalho da lavadeira, que tenta conservar o viço da sua cor original; o da costureira e o da bordadeira, que a criam, a consertam ou a embelezam, servirão de guia para o que ainda preciso dizer sobre o avesso das produções coletivas de comunicação.

Mas antes, a descrição ${ }^{64}$ das cenas do referido vídeo se faz necessária:

\section{Vídeo-documentário Processo}

\section{Cenário}

Estúdio da Rádio LEAS, composto por uma pequena mesa de som, gravador, caixas de som, microfones e uma mesa retangular, em volta da qual, tomando como referência o menino Marcos, de agasalho verde, no sentido horário, estão reunidos:

Paulo (9 anos)

Éder, próximo à janela do estúdio (10 anos)

Cíntia, a mediadora, auxiliar de educação que trabalha na secretaria da Escola Lea Edy Alonso Saliba (27 anos).

\footnotetext{
63 "Roup: antepositivo, do germ. ocidental *rauba 'butim, despojos tomados ao inimigo', cf. fr. robe (sXII), esp. e it. roba, prov. rauba, port. roupa (sXIII), pelo b.-lat. raupa (desde o s IX, apud João Ribeiro, que observa: "O butim freqüentes vezes consistia em alfaias e peças de vestuário, e por isso originou a expressão comum: roupa. Com o sentido de despojo de guerra e de pirataria sobreviveu na antiga expressão proverbial." (HOUAISS)

${ }^{64}$ Consideramos mais apropriado chamar de descrição, em vez de transcrição, dado o cunho subjetivo que lhe conferimos.
} 
Renata (10 anos)

Letícia, na extremidade da mesa (9 anos)

Marcos (10 anos)

\section{Parte I - Apresentação da mediadora (ou lavadeira, ou costureira, ou bordadeira...)}

Vinheta: Rádio LEAS - essa rádio é legal! ${ }^{65}$

Cíntia: Eu sou auxiliar de educação. Eu trabalho na secretaria, mais com a parte burocrática do que com a parte pedagógica. Mas em relação ao rádio, eu acabei me inclinando mais pra parte pedagógica, porque havia uma dificuldade das professoras... De tempo. Elas reclamavam muito de tempo, reclamavam de muitos projetos a serem executados... Então, como eu havia feito o curso, eu resolvi dar um apoio pra elas nessa parte.

Grácia: E como é esse apoio? Como é que você faz?

Cíntia: Bom, eu combinei que elas montariam os grupos, dividiriam a sala em grupos, montariam os programas, e depois eles viriam pra cá, pra gravar o programa, né?!

\section{Parte II - Constituição do corpo: da definição da pauta à produção}

Cíntia aparece escrevendo (ou "costurando") numa folha de caderno as decisões do grupo, dentre as quais a seqüência do roteiro do programa de rádio (a "roupa") que todos se propõem a

\footnotetext{
${ }^{65}$ O nome e a vinheta oficial de cada emissora de cada escola resultaram do envolvimento dos alunos na sua criação e escolha. No DVD encontram-se alguns exemplos das cédulas e tabelas de contagem dos votos ilustrativas desse processo.
} 
fazer: Tem a sugestão do LEAS, tem a minha, da festa. Mais alguém tem alguma outra sugestão?

Éder: Sobre a festa da primavera, sobre o túnel do Terror... Como vai ser a festa... É uma boa... Ela é legal...

Paulo repete, num tom mais baixo, a fala de Éder: Sobre a festa da primavera

Renata: Essas coisas... Que vai ter as brincadeiras...

Éder: A praça da alimentação...

Cíntia, entendendo que os assuntos levantados são todos relacionados à Festa da Primavera, propõe, então montar o roteiro do programa: Hum... Então, vamos estruturar o programa? Bom, a gente vai começar então, com? Com o quê começa o programa? Quando a gente liga o rádio, qual a primeira coisa que vocês ouvem?

Éder, lembrando de programas que já ouviu e realizou, arrisca: $A$ vinheta?

Cíntia reconhece publicamente que o menino está certo: $A$ vinheta!

Ouvem-se duas vinhetas:

1 - Rádio Amazonas - a rádio animal (criação da Escola Municipal Teresa Ciambelli Gianini)

2 - Rádio Estrela! (criação da Escola Municipal Oswaldo de Oliveira) 
Renata, radiante, já sugerindo o gênero radiofônico ${ }^{66}$ de um dos blocos do programa: A gente pode chamar alguém de alguma sala... pra entrevistar aqui!

Cíntia: Isso!

Éder, sugerindo possíveis entrevistados : Chama algum... a professora...

Paulo: a gente escolhe...

Renata, considerando a fala anterior, pondera sobre o número de entrevistados em relação ao tamanho reduzido do estúdio: $A$ gente chama alguma... um de cada vez...

Marcos, pensando na estrutura do programa ${ }^{67}$ : Tem que ter a âncora.

Paulo, ainda ocupado com a equação número de pessoas e estúdio pequeno, apresenta uma "saída": Entrevista ela mesmo, né?, referindo-se à sua sugestão de uma professora ser a entrevistada do programa.

Marcos, veemente, insiste na necessidade de bem planejarem a estrutura do programa: Tem que ter o âncora!

Marcos, ao mesmo tempo que passa a explicar a função de um âncora num programa, já pensa em como dividi-las, sem "deixar ninguém de fora": O âncora! Dois âncoras! Você não sabe o que é âncora?

Éder se arrisca a responder: O que vai...

\footnotetext{
${ }^{66}$ Para os fins que nos interessam dividimos os gêneros em apenas três: ficção, informativo e experimental, sobre os quais tratamos em maiores detalhes no capítulo II desta tese. Neste caso, a menina sugere que as informações sobre a Festa da Primavera sejam passadas por meio de entrevista.

${ }^{67}$ Sobre estrutura de programa de rádio produzimos um texto didático que se encontra disponível no site http://www.portalgens.com.br
} 
Marcos, como forma de facilitar o entendimento do termo, exemplifica: Sabe o Gugu? É um âncora!

Éder arrisca de novo: O Sílvio Santos é outro.

Marcos, vendo a dificuldade dos colegas, ilustra a função com o nome de um radialista conhecido da cidade: Não... Aí já é outra coisa. Âncora...sabe o Paulo Silas? Então, ele é um âncora! É o que chama, é o que fala, que fofoca...

Falas simultâneas mostram como vão estabelecendo o roteiro do programa e, ao mesmo tempo, a forma de apresentar cada uma de suas partes: Cíntia: Tá. Então, o primeiro bloco vai ser a entrevista com a Dona Isabel falando sobre a festa; Ah! / Paulo: Vamos pro intervalo. / Renata (entre risos): depois nós volta... / Cíntia: Fazer propaganda do quê?/ Renata: É... Depois nós volta...

Marcos, pondo a mão na cabeça e olhando para o alto, passa a se preocupar com o conteúdo da passagem de um bloco do programa para outro: O intervalo? Intervalo vai ser de... Ai meu Deus!

Éder, imitando a entonação de voz de algum locutor conhecido, mostra que nesse momento é importante inserir o nome da rádio da escola, como forma de o ouvinte saber que emissora está em sintonia : Rádio LEAS!....

Marcos, "amadurecendo a idéia" sobre o que pode compor a passagem, continua: $O$ intervalo pode ser de vender coisas...

Cíntia os provoca para que "delimitem o tema": E o que vocês vão vender?

Marcos, inquieto, somente ainda tendo claro a que se destinam intervalos de programas de rádio, diz: Vender... Vender igual no bazar aí...Vender... 
Éder, a partir das mercadorias que vê sendo vendidas nos estabelecimentos comerciais conhecidos, sugere: Vender doce, vender salgadinho...

Cíntia se empolga com as possibilidades levantadas, mas lembrando que o programa pretende divulgar a promoção de uma Festa, propõe ao grupo transformar o anúncio que serviria para "vender coisas": Ó! Aí a gente pode fazer propaganda do túnel, né?

Todos concordando com Cíntia, que parece ter conseguido "acertar em cheio", radiantes, "esticam" uma exclamação: Éeee!...

O grupo comemora a grande "sacada" da mediadora, sem nenhum constrangimento: o menino Marcos solta um grito, que é acompanhado de muitos risos de seus companheiros.

Paulo, tomando como descontrole a reação de Marcos, aponta-o com o dedo e sugere para Cíntia: amarra ele numa corda!

Cíntia, incitando para que pensem na forma melhor de traduzir toda a empolgação manifesta por interjeições e gestos, inicia uma frase, esperando que as crianças a completem: $A$ gente só não pode esquecer que no rádio a gente tem que usar...

Paulo arrisca, mais uma vez: ...a imaginação.

Cíntia, não discorda dele, mas, de modo bem objetivo, faz com que considerem uma das especificidades do rádio, ao mesmo tempo em que retoma com o grupo o roteiro: $O$ som, né?! Eles não vão enxergar o que você faz... Qual a primeira parte?...

Falas simultâneas: Marcos: Não, não: a primeira parte é festa./ Renata: põe a entrevista na segunda, depois..../Éder também opina: $E$ /Marcos: depois as entrevistas.../Cíntia: Ah, ta: na 
primeira parte a gente fala da festa /Éder: na segunda./ Cíntia:: e na segunda a gente entrevista a Maria Isabel?/

Falas simultâneas sobre possíveis dificuldades, iniciadas a partir do que diz Marcos, preocupado com o que poderá caber a ele no programa: É! Vou ter que decorar tudo aquilo... É que nem novela; é que nem novela! / Éder concorda: Tem que decorar... Então.../ Cíntia, esclarece: Mas aqui pode errar, não tem problema. Errou, continua. / Paulo reforça o que disse a mediadora: Não é como o Jornal Nacional. / Éder, igualmente, busca tranquilizar Marcos: Continua.../ Renata, enfática:

Engasgou? Continua.../ Marcos, convencido de que todos estão certos, então mais tranquilo, conclui: Engasgou? desengasga. / Letícia sorri.

Novamente falam juntos, desta vez para planejar o anúncio comercial que farão na hora do intervalo do programa. Renata sugere: Os ingressos estão à venda... / Uma outra voz não identificada: Hum! / Marcos, ao completar o texto da menina, se depara com um problema: Já estão à venda; na escola pra vender: Rua Manoel... Sei lá como é o nome da rua... Endereço... Sei lá! Número 1000.../ A mediadora sugere uma simplificação: Aqui na nossa escola, pronto! Mais fácil. / Éder completa a sugestão de Cíntia: "Aqui na escola Afonso Saliba".../ Renata assim conclui o texto publicitário: Aí no final a gente fala assim: "Compareça".

\section{Parte III - Considerações sobre o corpo}

Imagem mostra Marcos em $1^{\circ}$ plano, ajeitando com os colegas algo não identificado, dizendo: Lá em cima! É lá no teto, lá!

Diogo Noventa chama: Ô, Marcos!

Marcos, bem surpreso, responde: Oi! 
Diogo Noventa: O que você acha de fazer rádio?

Voz de menino, ao fundo: Legal!

Marcos, balançando o corpo e olhando para baixo: - Legal!

Legal, muito interessante e...

Ouve-se a voz de um dos meninos, ao fundo, assumindo o papel do entrevistador: Que mais?

Marcos, aparentemente bastante inibido, fala pro menino, enquanto se ouvem risos ao fundo: Você fica me atrapalhando, eu vou mandar você falar no meu lugar!

Risos das crianças, ao fundo.

Diogo Noventa: Fala, Marcos...

Marcos, parecendo estar "sem jeito": Repete a pergunta?!

Risos das crianças, ao fundo.

Diogo Noventa: O que você acha de fazer rádio?

Voz de um dos meninos ao fundo: Rádio é um assunto legal pra...

Marcos, dando impressão de timidez: Antes, eu não sabia o que era rádio ainda, entendeu? Eu sabia que rádio era uma caixa que nem...daquele jeito lá, ó! Eu não sabia como vinha som... Daí, com o curso...Com o curso...(erguendo a manga do agasalho) do "rádio-escola" eu aprendi que rádio...(erguendo, de novo, a manga do agasalho) tá me atrapalhando esse som, ó!...

Diogo Noventa: O que você aprendeu? Que rádio é o quê?

Marcos, erguendo ainda mais a manga do agasalho: Aprendi que rádio é uma coisa muito interessante; que dá pra aprender 
como é feito o rádio é...(ergue a manga mais uma vez) e como ele é transmitido para as caixas e todas as casas.

Menino, ao fundo, assumindo novamente o papel do Diogo: $E$ pra que mais?

Diogo Noventa: E pra que serve o rádio?

Marcos, sorrindo para o menino "entrevistador": É uma forma de comunicação com as pessoas.

Diogo Noventa: E o que você sente quando você faz programa de rádio?

Ouve-se, ao fundo, uma interjeição de surpresa, expressão de dificuldade: Hum!, como se estivesse pensando $A i$, ai, ai...E agora? O que eu responderia no lugar dele?.

Marcos, mexendo freneticamente uma das mangas do agasalho: Eu me sinto muito elegante. Muito feliz em fazer rádio. Falar ao vivo, gravar...

Voz de uma das crianças, ao fundo, imitando (ou se identificando com) o personagem Xaropinho, do Programa do Ratinho, transmitido pela televisão, que assim se manifesta quando o apresentador trata de um tema que comove o público: Rapaz!...

Diogo Noventa: Você gosta mais de fazer rádio ao vivo ou gravado?

Marcos: Gravado.

Diogo Noventa: Por quê?

Marcos, olhando para o teto: Porque ao vivo dá um negócio... Um negócio que você nem imagina! 


\section{Parte IV - Um pouco do lado direito de uma produção coletiva de comunicação}

Marcos, segurando o microfone, com voz firme: Olá! Aqui quem está falando é o comentarista Marcos. Nosso tema de hoje é a Festa da Primavera.

Éder: Vai ser realizada no dia 08 de outubro de 2004.

Sonoplastia: passos de pessoas (caixinhas plásticas de CD batem em compassos regulares, sobre a mesa) / Letícia sorri.

Texto, na voz (in off) de um dos meninos, enquanto na tela se vê um vídeo-animação produzido por crianças da Escola Municipal Julica Bierrenback: Saia da sua casa e venha para a Escola LEAS. É melhor você vim e entrá no túnel do terror, senão a noite vai esquentá e vocês vão ficar com os pé muuuuito assustado.

Sonoplastia: um som de horror, seguido de um grito agudo de uma das meninas: Aúuu!

Marcos: Voltamos de um breve intervalo. E acaba de chegar aqui, em nosso estúdio, a Maria Isabel, ela que é assistente de direção. Vamos entrevistar ela.

$\mathrm{Na}$ tela aparecem escritas (várias vezes, embaralhadas, para enfatizar que não acontecem em ordem linear) os movimentos da Metodologia Cala-boca já morreu para produções coletivas de comunicação. 


\section{"O conceito é o rascunho da imagem" (FERREIRA SANTOS, 2004:50)}

As imagens desse vídeo, tal como as vestimentas, muito nos contam sobre o corpo que revestem. Formada por um conjunto de idéias, elas dão mostras de que o corpo só se mantém no tempo, porque é sustentado por organismos vivos - neste caso, mais um bando de crianças $^{68}$, que nos incita a querer e continuar a ver e escutar mais e mais o que têm a nos dizer.

Exatamente porque são vivos, esses organismos são livres para dar um outro curso ao seu modo de tratar as coisas. A começar pelo curso da fala dissonante dessa passarinhada, por exemplo. Para entendê-la é preciso chegar mais perto e se esforçar para ouvir com maior clareza, porque suas vozes não se comportam. Elas saem movidas pelo entusiasmo e são livres, como é próprio dos que têm vigor. Entrecruzam-se, mesclam silêncios, risos, interjeições, e vão se completando, compondo um texto denso de significados, numa outra lógica à qual nossos ouvidos estão pouco acostumados.

Aos desavisados, ou habituados aos discursos cartesianos, que definem 0 conhecimento como capacidade exclusiva do pensamento, destituindo das experiências o valor cognitivo, podem soar como sinônimo de confusão, desordem ou mesmo como bagunça: falam todos juntos, não prestam atenção, não esperam o outro terminar seu raciocínio, diriam. Em se tratando de uma produção infantil, podem ser rotuladas, até mesmo por especialistas em educação, como uma atividade que visa mais ao divertimento que a qualquer outro objetivo; daí se explique, não raro, ser o tipo de ação colocada na escola, no período fora do horário de aula, como o recreio, uma vez que foge dos moldes do ensinar e aprender convencionalmente aceitos.

Porém, para quem chega mais perto e se mostra disponível para ver, o curto espaço de seis minutos e cinqüenta e dois segundos em que acompanhamos as imagens em questão (em que pese a presença da câmera de vídeo, um "elemento estranho"

\footnotetext{
${ }^{68}$ Faço alusão aqui às crianças que, em 1995, deram origem ao Projeto Cala-boca já morreuporque nós também temos o que dizer!, inspirador de vários Projetos e Programas voltados à produção coletiva de comunicação em diversas áreas sociais.
} 
ao grupo, que lhe diminui a espontaneidade) é suficiente para nos dar conta de que as expressões faciais, as entonações vocais e o gestual dessas crianças denotam conhecimento de diferentes naturezas.

Das características do rádio, por exemplo, elas mostram que as crianças sabem que esse meio de comunicação é essencialmente oral, ou seja, se vale da língua que todos os brasileiros, escolarizados ou não, usam nas suas relações cotidianas, dispensando a necessidade de uso das regras gramaticais próprias da norma padrão da língua. Não ignoram, no entanto, que há um modo de usá-la na "intimidade" ou na chamada "instância privada", e outro, para quando a comunicação se dá numa "instância pública", como a propósito esclarecem os PCNs - Parâmetros Curriculares Nacionais de Língua Portuguesa. Assim é que o mesmo menino que diz "cê num sabe o que é âncora?", enquanto, descontraído, prepara o programa, na hora da gravação se apresenta, mais formal, pronunciando pausadamente todos os sons contidos na sua apresentação "Aqui, quem está falando é o comentarista Marcos".

Para além desse efetivo domínio da língua, a prevalência da oralidade acaba por atribuir ao texto que constroem o sentido de tessitura ${ }^{69}$

um efeito que não seria apenas semântico, no sentido de comportar significações, mas comportaria, igualmente, um valor estético, uma fruição sonora que mobiliza nossos sentidos auditivos e vibracionais. Esta é uma experiência que podemos sentir quando apreciamos a declamação de um poema ou de uma leitura dramática de um texto teatral. Há uma musicalidade no texto que nos envolve e no qual, dependendo de nossa sensibilidade, podemos perceber a intrínseca harmonia sonora com seus significados professados pelas palavras.

(FERREIRA SANTOS, 2004:14)

As imagens também dão mostras de que as crianças sabem que intervalos fazem parte de programas de rádio, durante os quais são veiculados a vinheta da emissora

\footnotetext{
${ }^{69}$ Ainda segundo Ferreira Santos, em teoria musical, tessitura corresponde a combinações sonoras de timbres, frequências e tons diferentes que se harmonizam, conflitualmente, entre si.
} 
(não à toa, Éder, quando a mediadora pergunta sobre "o que tem no intervalo do programa", imita a voz de um locutor e diz: "Rádio LEAS"), como também anúncios publicitários destinados a "vender coisas". Não bastasse isso, revelam que são capazes de compor um texto publicitário para o meio radiofônico de acordo com a estrutura que caracteriza esse tipo de gênero:

1. Sonoplastia: passos de pessoas (caixinhas plásticas de CD batem em compassos regulares sobre a mesa).

2. Texto: Saia da sua casa e venha para a Escola LEAS. É melhor você vim e entrar no túnel do terror, senão a noite vai esquentar e vocês vão ficar com os pé muuuuito assustado.

3. Sonoplastia: (som assustador): Aúuu!, seguido de um grito agudo de uma das meninas.

De um jeito simples, porém adequado ao que foi planejado, o anúncio vai ao ar, servindo para divulgar a brincadeira do túnel e, certamente, para inspirar outras crianças, de outras salas ${ }^{70}$ a também produzirem comerciais, semelhantes na intenção e na estética.

Uma outra dobra desse corpo (já tão exposto) nos será revelado, justamente pela menina que não faz uso da palavra durante todo processo, mas que, no entanto, se mantém na cabeceira da mesa. Seu semblante sereno, seus olhos brilhantes, seus acenos de aprovação com a cabeça retiram do silêncio muito do que precisa ser contado para quem quer entender do que estamos tratando.

As propostas de produção coletiva de comunicação, porque pretendem ser desencadeadoras de processos de autoria, devem respeitar o ritmo de cada um. Se quisermos que as pessoas se tornem cientes de que são seres de criação, é preciso

\footnotetext{
${ }^{70}$ No sistema de rádios escolares internas de Sorocaba, em cada sala de aula há uma caixinha de som que veicula diariamente, durante 5 a 15 minutos, os programas produzidos pelas crianças. No momento em que a rádio entra no ar, as atividades pedagógicas se voltam para o exercício da língua oral que pressupõe desenvolver alem da capacidade de falar, também de ouvir.
} 
aprender a celebrar a vida que delas brota a cada segundo vivido. Assim como a natureza, as pessoas não são e não precisam mesmo ser iguais, muito menos devem ser cobradas para que sejam tais quais às outras. Ao contrário: as diferenças contribuem para a tessitura, como harmonia conflitual.

É da combinação de elementos diferentes e individualizados, mas ligados por uma relação de pertinência, que nasce a sensação boa e de prazer por fazer parte de um todo, como podemos perceber nas feições dessa menina, ao longo do vídeodocumentário. Ao menos no dia da gravação, ela estava mais para sorrir e prestar atenção do que para emitir parecer sobre os temas que surgiam ou o formato do que ia sendo tecido. No entanto, estava inteiramente envolvida consigo, com seus companheiros (as imagens a mostram, atentamente olhando para cada um deles) assim como com o trabalho.

Essa pequena nos diz, silenciosamente, entre outras coisas, que é subjetiva a relação que estabelecemos com o tempo; que as pessoas e as coisas são mutáveis; que não existe somente um jeito de se fazer presente; que a maior dádiva que recebe aquele que se abre para a criação é sentir o sabor da alegria pelo instante vivido; que erra quem rotula as pessoas por apenas um pequeno pedaço de sua trajetória, principalmente porque nem tudo que a cabeça pensa é.

E assim, em torno de uma mesa simples, sob os cuidados de uma mulher, meninos e meninas, efusivamente, vão aprendendo a tratar da vida, transformando-a em matéria a ser partilhada com mais gente através dos programas de rádio que juntos produzem.

Cíntia (na mitologia grega, aquele que habita a Ilha de Cinto), faz lembrar a deusa Artemis (ou Diana, para os romanos), que mesmo sem a experiência de ser mãe, era protetora do parto e das criaturas novas. Sua figura, pois, é emblemática para o que chamamos de mediação nas produções coletivas de comunicação.

A Cíntia, da Escola LEAS, embora leiga em Educação (ela é auxiliar administrativa de secretaria) se põe a "zelar" pelo projeto que começa a ser implantado naquela unidade escolar, determinada a transpor aspectos burocráticos que impeçam as crianças de usufruir de um equipamento público, no caso, a rádio, espaço potencialmente destinado ao exercício da criação. 
Com a sensibilidade apurada dos afeitos à formação de pessoas, ela acaba se "inclinando mais pra parte pedagógica". "Dis-posta" a ouvir com atenção concentrada as queixas das professoras que "reclamavam muito de tempo, reclamavam de muitos projetos a serem executados", percebe que pode servir-lhes de "apoio". Desloca-se, então, do papel burocrático para, dali pra frente, a apontar procedimentos pedagógicos para que se realizem a contento as ações previstas no Programa de Educomunicação de Sorocaba.

Sabendo que quanto mais cedo as crianças pequenas começarem a se envolver com criação coletiva de comunicação, maiores são as possibilidades de se tornarem desinibidas, capazes de conversar em pé de igualdade sobre qualquer tipo de assunto com qualquer tipo de autoridade, ela passa a dar, com segurança, as devidas orientações para as professoras das séries iniciais do Ensino Fundamental: "eu combinei que elas montariam os grupos, dividiriam a sala em grupos, montariam os programas, e depois eles viriam pra cá, pra gravar o programa, né?!".

O mediador, conclui-se, é uma pessoa movida por convicções, que funcionam não como armas apontadas para atacar um possível inimigo, ou dele se defender, mas como guias para realizar-se através do que promove com o outro. Uma delas é a de que inserir a comunicação, na perspectiva da Educomunicação, na escola ou em outros espaços, não tem o propósito de facilitar o trabalho deste ou daquele, visando amenizar as relações, menos ainda o de seguir os ditames da moda. Muito pelo contrário: o mediador sabe que as resistências fazem parte de uma engrenagem que tenta emperrar o desencadeamento de propostas que optaram pela autonomia. Por isso é destemido e revela, nomeia, torna explícitas as contradições.

Contudo, essa figura não pára na denúncia, não assume o papel ingênuo de acreditar que técnicas trazem solução aos problemas humanos, nem tampouco assume o papel messiânico de apontar as melhores "saídas" para a vida das pessoas; ele procura caminhos que levem os próprios participantes a decidirem o rumo que querem dar às suas histórias, ciente de que 
(o homem, um ser de relação com o mundo) “..não poderia afirmarse como tal, senão em relação com ele. É homem porque está sendo no mundo e com o mundo. Este estar sendo, que envolve sua relação permanente com o mundo, envolve também sua ação sobre ele"

(FREIRE, 1992:42)

Vencida a etapa de convencimento das professoras, tendo conseguido que as crianças e a rádio ficassem sob sua guarda, o vídeo nos leva a ver a mediadora, a partir de agora, com o bando de crianças.

Corajosa $^{71}$, ela permite que as imagens despojem sua ação diante dos olhos dos espectadores, à semelhança do que faz o vento com nossas roupas penduradas no varal.

E aí a vemos, com os meninos e meninas criadores. Não se coloca à frente, nem atrás ou em pé, mas, sentada ao lado deles, como quem busca entender as tramas do longo e difícil caminho de aprendizagem da convivência com o outro. Em nenhum momento se confunde com eles, entretanto. Seria no mínimo ingênuo (ou piegas) querer ser ou parecer igual a eles. Esse lugar que ela ocupa é lugar de gente adulta, madura, sensata, que tem clareza de onde quer chegar.

Mediador é alguém que de dentro do grupo, por intencionalmente desenvolver a sensibilidade, a capacidade de escuta do outro, tem condição de devolver a ele o que percebe na dinâmica das relações que estabelecem. Atento aos movimentos de todos e de cada um em particular tem condição de promover conversa sobre como lidam com uma determinada tarefa, como se tratam ao desenvolvê-la e os tipos de valores expressos nas atividades que juntos realizam. Ou seja, é alguém comprometido com a formação de pessoas para um outro relacionamento social, voltado para um outro tipo de sociedade, porque não concorda com a que construímos ao longo de séculos. Porque conhece essa, é que sonha com outra e busca mecanismos para tornar clara a mais gente quanto precisamos aprender a ser

\footnotetext{
${ }^{71}$ Do francês, 'disposição nobre do coração (coeur + sufixo -age), qualidade espiritual de bravura e tenacidade'
} 
solidários e generosos; a considerarmos o outro como indivíduo e não como nossa propriedade, menos ainda como meio para satisfazer nossas vaidades.

Mais uma vez, vale ressaltar: a inclusão de rádio, vídeo ou qualquer outra tecnologia nas propostas de Educomunicação devem ser tidas e tratadas como ferramentas (assim como o foram a lasca de pedra ou o grafite) que, uma vez estando em nossas mãos, servem para "escrever textos" que estampam nossas idéias e nossas emoções acerca de nós mesmos, dos outros com quem convivemos, da vida que juntos estabelecemos em determinado momento de nossas existências. Por isso dizemos, por extensão, que escrever é escrever-se. As imagens, os sons, as palavras que de nós saem deixam marcas, assim como as pegadas que deixamos no chão.

Do mesmo modo que servem para "nos escrevermos", também nos são valiosas porque podem nos permitir entender o que fizemos por meio delas. Vale dizer, se transformados em objeto de conhecimento, os programas de rádio, os escritos e as imagens que produzirmos promovem um tipo de leitura voltada para o autoconhecimento.

Nesse sentido dizemos também que ler é ler-se (Ricoeur, 1989). Esse exercício de escrever e ler o que nós mesmos "escrevemos" com as tecnologias possibilita nos reconhecermos como autores. Por isso afirmamos que se assim for, estamos envolvidos numa proposta de educação. Estamos nos educando para reconhecermos através das nossas produções o que fazemos de nós, o que fazemos com os outros com quem estamos, o que buscamos, o que sonhamos. Tudo isso fica escrito. O que falta é aprender a ler. Daí a importância do mediador. Ele é um sujeito que pode ensinar o grupo a ler e escrever.

Cíntia é uma dessas pessoas que se pôs a caminho dessa aprendizagem. Ela sabe que não é à toa que esta proposta de produção de comunicação é coletiva; que muito mais simples seria se nesse trabalho cada um desempenhasse apenas uma função, de acordo com suas habilidades e competências, como se dá na produção de comunicação pautada pelos princípios de mercado. Bastaria juntar os pedaços num produto final e pronto. 
Quando se trata de produção coletiva o mediador não tem controle sobre as pessoas. É um papel que exige maturidade: é preciso ser seguro o suficiente para não querer ser obedecido ou ficar melindrado, quando não raivoso, quando o grupo escolhe um rumo diferente do que imaginou. Ele "está dentro" do grupo, mas distanciado dele o suficiente para enxergá-lo "de fora" (Ricoeur, 1989), e assim conseguir interpretar e partilhar o que "lê" sobre o que vivencia nele e com ele.

Quando o grupo, por seu turno, reconhece na figura do mediador essa pessoa que, embora diferente dele, também participa ativamente da constituição da história social do grupo, devolve a ele o que dele recebeu: a amorosidade, o bem-querer. No vídeo em questão essa simpatia das crianças pela mediadora é transparente. Ela se contrapõe em várias passagens ao que planejam, não para corrigi-los, mas para que re-pensem o que de chofre Ihes veio à boca. Ela questiona, mas respeita o tempo $\mathrm{e}$ o ritmo das crianças, não se sobrepondo a elas, tampouco "fazendo de conta" que é neutra na produção. Porque é explícita aos seus olhos, porque lhes permite ver a costura da roupa que está sendo alinhavada é que acolhem suas palavras e deixam nítida a qualidade do vínculo que os une. Por isso, traduzem a ternura que nutrem por ela nos tantos risos que incorporam ao texto imagético.

Outra figura emblemática que nos permite visualizar mais de perto o lado de dentro do processo de produção coletiva de comunicação é o menino Marcos.

As imagens de Marcos, do latim, martelo, "peça de ferro forjado destinada a reter o navio no ponto em que se quer", nos confirmam tratar-se mesmo de um "meninohomem" de "pés no chão", voltado para questões objetivas e práticas. Suas duas primeiras intervenções já anunciam que estamos diante de alguém que sabe que não basta definir um tema (ou um rumo) para o programa. Isso é pouco. É preciso pensar numa estrutura suficientemente sólida que garanta que seu objetivo seja alcançado. Por isso diz com veemência, quando o grupo está definindo o gênero e a forma do programa: "precisa ter um âncora", porque o âncora "é o que fala, o que chama, o que fofoca", ou seja, aquele que se responsabilizará "com sua agulha e linha" por unir parte por parte da "peça de roupa" trabalhada. 
Mais adiante, seguindo a mesma lógica de raciocínio, baseado no que conhece por observação é quem sugere, resoluto, que o intervalo do programa pode "ser de vender coisas", "Vender... Vender igual no bazar aí... Vender..."

Fosse um adulto, a julgar por essas passagens, facilmente seria tomado por um "homem do tipo prático", com acentuada capacidade de passar logo à ação e não perder tempo com elucubrações. Ocorre que Marcos preserva os dotes de menino: ainda é capaz de sentir a força da brisa e dobrar-se com a disponibilidade para o crescimento próprio dos brotos, com intensidade similar à do ferro que se permite forjar para transformar-se em mais um instrumento a serviço dos homens. Talvez isso explique, durante a produção do programa de rádio, que ele incorpore ao seu discurso, com a mesma magnitude que empreende às questões objetivas, tantas expressões faciais de espanto, interjeições ( $A i$, meu deus!) e até gritos, a ponto de desencadear muitos risos em seus colegas e até mesmo passar-lhes a impressão de descontrole ("amarra ele numa corda!", sugere o menino Paulo a Cíntia, quando Marcos comemora a transformação de "venda de coisas" na divulgação da brincadeira do túnel da festa).

A mesma brandura de Marcos é visível no momento em que acata os conselhos do grupo que busca acalmá-lo sobre a aventada necessidade de ter que decorar o conteúdo do programa. Ele que, até então, tem para si o modelo de comunicação comercial fixado por meio de programas populares, como novela, e personagens conhecidos, como Gugu e Paulo Silas, para ele símbolos da própria definição do conceito "âncora", compreende que a rádio da escola tem compromisso com outro tipo de comunicação. Quando ouve "aqui pode errar, não tem problema"; "errou, continua; não é como o Jornal Nacional"; "engasgou? Continua!", fica convencido de que seus companheiros estão certos, de que, de fato, estão todos eles envolvidos com propósitos de criação e não de imitação, Marcos deixa de se preocupar com ter que "decorar tudo aquilo". Uma vez tranquilo, repete como sinal de assimilação interior, as palavras simples da outra sábia menina "Engasgou? Desengasga”, ou seja, compreende que a essência dessa pequena emissora radiofônica é desentalar a palavra da garganta, deixando que ela saia livre, com a feição de quem lhe dá à luz. 
A postura, os gestos e, principalmente a energia que esse menino emprega às suas palavras, possuem a força de um manifesto dirigido a todos os interessados em entender o que significa exercer o direito de produzir comunicação e o que representa a produção coletiva de comunicação na perspectiva da Educomunicação.

Sem nenhuma alusão a declarações feitas em púlpitos ou palanques, suas palavras nos lembram roupas coloridas expostas ao sol, penduradas no varal em profundo diálogo com o vento.

Marcos nos encanta ainda mais na parte final do documentário, quando tece considerações sobre "fazer rádio". O que, à primeira vista parece desassossego (ele, freneticamente ergue as mangas do agasalho, bem como movimenta os olhos para cima, para baixo, para os lados), distração ("repete a pergunta!"; "ta me atrapalhando esse som"), ou nervosismo, agora, numa leitura mais acurada, assume outra conotação. Nesse momento ele se encontra procurando o melhor jeito de dizer o que precisa. Esse menino, na sua singeleza, tem noção de que conceder entrevista é "desnudar-se" diante do público. Daí que, ao res-ponder ${ }^{72}$ as questões levantadas, alarga os horizontes do nosso pensamento.

Seu discurso começa com a declaração de que "fazer rádio" é "muito legal, muito interessante". Só essa frase, composta por dois adjetivos já nos traz importantes significados da proposta. "Legal", termo extraído da língua oral (o "chão" onde se assenta nossa vida cotidiana), logo explicado de forma mais erudita, nos permite entender que a tecnologia pode instigar a vontade de saber. Segundo a filologia, o vocábulo "interessante", com o qual conclui a idéia, se traduz como "tudo aquilo que motiva, que é intrigante". Porque não entedia, logo é digno de atenção, donde se compreende porque Marcos afirma que com o rádio "dá pra aprender", desde "como é feito e como é transmitido para as caixas e para as casas" até para quê serve.

Mas, seu discurso não para aí. Uma vez exposta ao sol, "essa roupa" vai se colorindo mais e mais à medida que o menino lhe acrescenta elementos novos: os equipamentos tecnológicos não são nem mais nem menos que outras ferramentas

\footnotetext{
${ }^{72}$ Tomada no seu sentido filosófico, "resposta" não é sinônimo de definição, mas, sim, de trazer as coisas (tudo quanto existe ou possa existir, de natureza corpórea ou incorpórea) ao mundo da problematização.
} 
de expressão. Eles representam apenas isto: outra "forma de comunicação com as pessoas". Aliás, só adquirem sentido, quando efetivamente servem para envolver pessoas em ação em comum.

Ao final, Marcos - o grande orador, outra potência do nome que o leva a cumprir o seu destino, como nos lembra Ferreira Santos (2004) para arrematar, diz se sentir "muito elegante, muito feliz em fazer rádio, em falar ao vivo, gravar". Não poderia ser outro o fecho de um processo tão intensamente vivido com o bando.

Fosse pretensioso ou arrogante, poderia ter feito uso de outro termo para expressar seus sentimentos, afinal foi eleito para aparecer diante de uma câmera similar à de que se serve uma série de astros e intelectuais destacados pela mídia que, quase sempre, espalham palavras que contribuem para que as pessoas se considerem sempre menos capazes que as outras.

Mas, aqui, outra vez, Marcos amplia nosso pensamento. O termo elegante derivado da raiz grega e latina leg-, significa 'escolher'. Com o passar do tempo, associado a legere (ler), lógiké (lógica) e elegans (elegante), todos relacionados à predileção pela perfeição - se associou estritamente ao comportamento humano, ou mais precisamente, ao que se convencionou chamar de beleza.

Mas não é dessa última preferência que Marcos faz menção. Ele não está se referindo ao aparente. Quem, como Marcos empreende uma jornada com tamanha doçura e flexibilidade se torna elegante, porque escolhe a perfeição como sinônima de escolha por um estilo que possibilite a ele a compreensão de si mesmo. 


\title{
“(...) E só debaixo do esterco besouros têm arrebóis. O que
} sei aprendi no galpão (...)" (MANOEL DE BARROS, 1997: 68)

Um bando de crianças e uma mulher nos concederam permissão para com eles sentarmos na mesma mesa sobre a qual uma vestimenta estava posta. Passamos vagarosamente os dedos sobre sua superfície. Sentimos o tamanho dos nós que iam lhe dando acabamento: todos bem pequeninos, esmerados em capricho. Vimos a tesoura sendo usada com precisão, a todo instante, para aparar as pontas da linha do arremate. Acompanhamos mãos indo e vindo, fazendo e refazendo, assim como olhos muito atentos em busca de acessórios para o seu refinamento.

Estão certas as bordadeiras e costureiras quando dizem que um bom trabalho se reconhece não só pelo que aparece do lado direito, mas, principalmente, quando se olha o avesso e nele se vê o mesmo cuidado dedicado ao que fica de fora. O mesmo princípio vale para as atividades voltadas para a produção coletiva de comunicação, na perspectiva da Educomunicação. Seus produtos tornam-se preciosos quando na mesma proporção estampam processos sustentados numa Educação, cuja potência

\begin{abstract}
instauradora de sentidos possibilita a comunicação entre as pessoas na medida em que elas se ensinam como tais. Ensinamento como tentativa de colocar o outro em sua própria sina, despertando-o, para que parafraseando Kierkegaard, não siga o nosso caminho, mas, ao contrário, insistindo para que ele siga o seu.
\end{abstract}

(FERREIRA SANTOS, 2004: 65)

Pelo que vimos, os alunos da escola Edy Alonso Saliba tiveram bons motivos ao eleger para apresentar sua emissora a vinheta que diz: essa rádio é legal! 
A Rádio LEAS, diferentemente das grandes emissoras espalhadas por todo país, recebe do seu público não só a aprovação de sua programação como a permissão de "legalmente" permanecer no ar, porque, comunitária que é, assegura ao ouvinte não só o direito de receber informação, como também o de produzir comunicação. 


\section{CONSIDERAÇÕES FINAIS}

Este estudo teve como tema a Produção coletiva de comunicação, na perspectiva da Educomunicação. Propôs-se a dois objetivos: evidenciar que tal produção é uma manifestação de cultura, bem como uma possibilidade real de se configurar numa educação pelos meios de comunicação. Para tanto, estruturou-se em três capítulos.

No primeiro, apresentamos alguns princípios da Pedagogia Libertária e da Comunicação Comunitária, que embasam as produções coletivas de comunicação, na perspectiva da educomunicação, realizadas pelo GENS -Serviços Educacionais, desde 1995, a partir da criação do Projeto Cala-boca já morreu.

No segundo, expusemos a "Metodologia Cala-boca já morreu" para produções coletivas de comunicação, na perspectiva da Educomunicação, concebida e aprofundada, num movimento de ação e reflexão constantes, ao longo da trajetória profissional empreendida pelas duas instituições que lhe deram origem.

Por fim, no terceiro capítulo, ilustramos a tese defendida com a descrição subjetiva de um processo de criação coletiva de um programa de rádio, vivenciado por um grupo de crianças do Ensino Fundamental e uma assistente de educação, à luz dos Estudos do Imaginário.

A análise qualitativa dos dados obtidos durante a pesquisa-ação, que teve como estudo de caso as produções coletivas de comunicação, na perspectiva da Educomunicação realizadas pelo Projeto "Cala-boca já morreu - porque nós também temos o que dizer!”; Oficinas de rádio Ondas Paranóicas; Revista Engrama; 
Programa de rádio Embalos de domingo à tarde, SP; Programas de Educomunicação dos municípios de Vargem Grande Paulista Sorocaba, Sorocaba, Piedade, Alumínio e Atibaia, SP; Programas de rádio do Projeto educom.rádio, São Paulo, SP; Oficinas de vídeo realizadas durante a Mostra Nacional de Cinema de Paraty, Rio de Janeiro; Oficina de rádio O que aprendi com meus pais, Peruíbe, SP; Produções de rádio do Programa Juventude e Meio Ambiente, MEC e MMA; Produções de rádio das três Conferências nacionais Infanto-Juvenil Pelo Meio Ambiente, MEC e MMA; Produções de rádio e fotonovela dos alunos de Pedagogia da Faculdade Sumaré, São Paulo, SP, nos dá como comprovadas as principais hipóteses levantadas no início do trabalho.

Os processos de produção coletiva de comunicação, na perspectiva da Educomunicação:

\section{a) possibilitam o encontro com o repertório cultural cotidiano de seus realizadores.}

Os grupos, quando se auto-convocam para produzir comunicação, na perspectiva da Educomunicação, dão início ao envolvimento de seus participantes numa proposta de Educação, que se apóia na comunicação social como seu instrumento desencadeador.

Ou seja, sustentam-se em dois aspectos peculiares desse tipo de proposta. $O$ primeiro diz respeito ao conceito de Educação que, tomada como fim em si mesma, é voltada para o tempo presente de cada um dos integrantes do grupo. Partindo da negativa, posto ser mais fácil entender algo a partir do que é comum ao cotidiano da maioria de nós, essa educação não é sinônimo de formação profissional, visando a, depois de determinado tempo, inserir o participante (jovem ou adulto) no mercado de trabalho; ela não se propõe a formar educador ou comunicador; portanto, não ocupa o tempo para oferecer informações e técnicas; tampouco é uma educação voltada para o assistencialismo, visando a suprir qualquer tipo de carência, uma vez que essa postura, já de antemão, assinalaria superioridade de que quem a 
oferece em relação a quem dela vier fazer parte. Não se confunde com ato de benevolência, por conclusão.

A educação aqui é concebida como possibilidade de cada encontro, tenha ele a duração que tiver, ser um momento que possibilite a cada um dos indivíduos do grupo, em condições de igualdade, entrar em contato consigo mesmo, sem se assemelhar, contudo, a trabalho de auto-ajuda. Nada disso. Há clareza quanto ao objetivo dos encontros. Os grupos se reúnem para exercitar o direito humano de produzir comunicação, ou seja, para transformar em uma peça de comunicação (programa de rádio, vídeo, jornal impresso ou virtual, site, entre outras), o que sentem e pensam sobre assuntos de seu real interesse. A educação que nesses momentos acontece é sinônimo de possibilidade de cada indivíduo se envolver nessa ação direta de fazer algo, à procura de suas próprias idéias e emoções a respeito dos temas que decidiram abordar. Como não há chefe nesse tipo de tarefa, o produto da comunicação assume sempre a feição daqueles que 0 idealizaram, confeccionaram e finalizaram. Educação aqui é sinônimo de criação. O produto de comunicação que resulta dessa educação para o presente é, nesse sentido, uma produção artesanal, que permite aos seus realizadores se re-conhecerem como autores, de fato, pois dão vida material ao trabalho de seu intelecto e imaginação.

O segundo aspecto se refere ao conceito de comunicação. As produções coletivas de comunicação, na perspectiva da educomunicação são compromissadas com a comunicação social comunitária. Ou seja, uma comunicação, cuja intenção maior é estreitar os vínculos entre as pessoas de pequenas comunidades. Diferentemente dos meios de comunicação, sob controle de grupos empresariais que os utilizam para tirar proveito em benefício próprio, incentivando o consumo de bens simbólicos como forma de garantir a venda de bens materiais e serviços, a comunicação comunitária se assenta no princípio do fortalecimento da comunidade local, não como entidade abstrata, mas como um grupo formado por indivíduos identificáveis, que estreitando laços podem, juntos, decidir o que melhor lhes convém. As palavras e imagens que nascem sob essa égide saem carregadas de sentido. Não são discursos decorados. São formas dadas ao que de mais de dentro 
saem daqueles que as materializam. São símbolos dos seus mais internos sonhos, desejos e necessidades. Daí que, ela, uma vez partilhada, coloca os indivíduos em comunhão, ou seja, em contato direto com o que possuem em comum - a capacidade de fazer da vida uma jornada para se constituírem como sujeitos plenos e autônomos, capazes, portanto de conviverem com a diversidade. Por seu turno, os produtos de comunicação gerados sob este princípio, necessariamente trazem os olhos e os ouvidos do receptor para mais perto do ambiente em que se encontram. À medida que as mensagens Ihes permitem reconhecer a voz e a imagem das pessoas e dos espaços conhecidos, passam a atribuir aos meios de comunicação a função que lhes cabe nesse tipo de educação: a de serem meios, ou mais propriamente, ferramentas úteis para um trabalho de re-visão, re- avaliação do que pode ser mantido ou alterado no território local, não por acatamento de resolução emanada de alguma autoridade superior, mas por escolha dos indivíduos comuns, que se colocam em condição de igualdade para fazer suas opções.

É nesse sentido que as produções coletivas de comunicação, na perspectiva da Educomunicação acessam o repertório cultural cotidiano de seus realizadores. Elas desencadeiam processos que permitem aos grupos conhecer o universo simbólico de cada um de seus integrantes e, consequentemente, do grupo que formam por livre escolha.

\section{b) pautados pelos princípios da Metodologia Cala-boca já morreu possibilitam uma relação mais solidária entre as pessoas;}

O modo com que são desenvolvidas as produções coletivas de comunicação, na perspectiva da Educomunicação distancia-se de qualquer intenção de condicionar a ação a cumprimento de regras. As técnicas e métodos engessam. A metodologia em referência expressa um jeito, um estilo de produzir, sinônimo de gerar ou, mais diretamente, de procriar. É a isso que ela se destina: a instigar os grupos para se envolverem em atos de criação, somente possíveis de acontecer se houver contato estreito, íntimo, entre seres da mesma espécie. 
Nos grupos que se orientam pela metodologia Cala-boca já morreu verifica-se que o elo que une os seus participantes e que os mantém é exatamente o vínculo que estabelecem uns com os outros. É comum, ao se perguntar a um novato do grupo "o que trouxe você para cá?" ouvirmos a mesma resposta "Porque fulano falou que era legal, eu vim!" Qual significado assume esse termo "legal", considerando que os recém chegados sabem que o grupo se junta para realizar a tarefa que se auto-atribuem de produzir comunicação? Entendemos que essa resposta enfatiza o sentido já atribuído à comunicação, na perspectiva da educomunicação: o de ela ser resultado de uma ação coletiva, marcada pela real possibilidade de cada indivíduo entrar em contato com as suas próprias palavras, à medida que aprende a estabelecer diálogo com o outro.

As con-versas, isto é, as palavras trocadas entre os participantes dos grupos, geradas a partir da necessidade de definirem uma peça de comunicação, porque não seguem uma lógica formal, geram dis-cursos, ou seja, correm para diversas partes, tomam várias direções, abrindo-se, enfim, ao universo da criação. E onde há invenção há alegria. Esse prazer legitima (torna legal) o ato coletivo de criação.

"Cala-boca já morreu", o nome da metodologia em questão, contribui para que os grupos entendam que todos possuem o direito da livre expressão; que como seres humanos que somos, nascidos para a liberdade, façamos uso da palavra para continuarmos nos constituindo como indivíduos, ao longo da nossa jornada.

Nos estudos de caso deste trabalho observamos que todos se põem a produzir comunicação em sistema de co-operação, isto é, trabalham diretamente no produto criado. Porque prevalece, no processo, o respeito pelo cada um é, torna-se possível a solidariedade, que não é outra coisa senão o fortalecimento de cada um individualmente e do grupo como um todo. 


\section{c) podem contribuir para uma educação efetivamente comprometida com o fortalecimento do indivíduo e dos grupos;}

Os processos de produção coletiva, como apresentados neste estudo, são o cerne das propostas, o elemento que Ihes fornece o vigor necessário para resistir a qualquer tipo de apelo que altere seu percurso.

Muito embora não se faça apologia ao descaso com a forma, muito menos que se dispensem os recursos sofisticados da tecnologia, nem sempre os produtos de comunicação dos grupos são bem acabados do ponto de vista técnico. Não raro, eles próprios reconhecem essa pouca qualidade e a apontam como algo que, numa próxima vez, precisa ser mais trabalhado. No entanto, isso em nada diminui o prazer que sentem ao entrar em contato com suas produções já concluídas. O motivo parece bastante simples: o produto guarda a memória de um tempo especial para o grupo. As imagens, as palavras e os sons que nele se eternizam são representações da coexistência de várias histórias num só material: a de um com todos, de um com cada um, de todos com todos e a de cada um consigo mesmo. Parece não vir à toa a frase tão freqüente ao final de muitas apresentações: Nossa, deu um trabalho! ou Só a gente sabe o trabalho que deu!

O produto faz re-(cord)ar o significado da parte mais preciosa dessa proposta de Educação pelos Meios de Comunicação - o processo coletivo de criação. 


\section{Apontamentos}

Este trabalho escrito acaba aqui, refletindo bem as suas circunstâncias. Tentei traduzir, através dos verbos na primeira pessoa do plural, um pouco do que venho, há anos, observando-pensando-fazendo, junto com um bando de gente boa pelo caminho. Não sei o quanto consegui.

Saio feliz, com uma grande certeza: as atividades de produção coletiva de comunicação, na perspectiva da Educomunicação, exigem que seus proponentes olhem muitas e muitas vezes o lado do trabalho que não aparece.

O mirar profundamente o processo é fundamental, pois ele permite chegar na intimidade do ato da criação. Sondando de perto esse momento, a gente percebe que a vida não é cindida, por natureza. Razão e emoção, corpo e mente ali se encontram, entrelaçando uma coisa só.

Examinando com profundidade o avesso desse trabalho fica visível que ele é, de fato, sinônimo de procriação. Os que dele participam são vocacionados, já a partir dos primeiros passos, a se constituírem indivíduos, tão plenos quanto a vida que os gerou.

Observar em silêncio os pequenos detalhes das imagens e dos sons (ou ausência deles) que vêm daqueles com quem a gente colabora, gera uma inquietação necessária que instiga a vontade de querer saber mais.

Refletir sobre a ação, ao lado dos indivíduos que constituem os grupos, traz aos que se propõem a realizar o trabalho de produção de Educomunicação, a confirmação de que, de fato, não é o lado direito do bordado e da costura que mostra se o trabalho está bem feito: é o avesso. Mais: que o cuidado inicial com a confecção da vestimenta deve ser exatamente o mesmo de quando ela, já usada, para não descorar, exige que a gente chacoalhe várias vezes, antes de estendê-la no varal.

Assim, saio com a convicção de que os trabalhos de Educação pelos Meios de Comunicação podem ser considerados como intervenção social, porque mexem naquilo que mais caracteriza os seres humanos - a sua capacidade de se fazerem sujeitos livres e autônomos. 


\section{Referências bibliográficas}

ARBEX, José Jr. "Uma outra comunicação é possível (e necessária)". In: MORAES, Dênis de. Por uma outra comunicação. Mídia, mundialização cultural e poder. Rio de Janeiro: Record, 2003.

ANDRADE, Maria Olívia M de. In "Gerontologia Educacional”. Mariuza Pelloso Lima. Revista Kairós, do Núcleo de Estudo e Pesquisa do Envelhecimento, da PUC SP. Volume 4, EDUC. Gerontologia Educacional:pp 109- 121, 2001.

BACHELARD, Gaston. A água e os sonhos. Ensaio sobre a imaginação da matéria. São Paulo: Martins Fontes, 1997.

BAGNO, Marcos. Preconceito lingüístico, o que é, como se faz. São Paulo: Edições Loyola, 1999.

BAKUNIN, Mikhail. La liberdad. Barcelona. Editora Júcar, 1980.

BARBOSA, Elyana e BULCÃO, Marly. Bachelard Pedagogia da Razão. Pedagogia da Imaginação. Editora Vozes, Rio de Janeiro: 2004

BARROS, Manoel. Memórias Inventadas. Segunda Infância. Editora Planeta do Brasil, São Paulo: 2006.

BARROS, Manoel. Livro de Pré-coisas:roteiro para uma excursão poética no Pantanal. Record Editora. Rio de Janeiro: 1997.

BARROS, Manoel. Poemas rupestres. Rio de Janeiro - São Paulo: Record, 2004.

BARROS, Manoel. Concerto a céu aberto para solos de ave. Rio de janeiro: Editora Civilização Brasileira, 1991.

BARROS, Manoel. Arranjos para assobio. Rio de Janeiro: Editora Record, 1998.

BARROS, Manoel. Memórias inventadas. A infância. São Paulo: Editora Planeta do Brasil, 2003. 
BERGAMASCHI, Maria Aparecida. Narradores de Javé: a memória entre a tradição oral e a escrita. 1996. Disponível em www.museu.ufrgs.br/admin/artigos/arquivos/NarradoresJave.doc. Acesso em 15 de janeiro de 2009.

BEZERRA, Heloisa Dias. Atores políticos, informação e democracia. Opin.

Publica, Campinas, v. 14, n. 2, nov. 2008 . Disponível em:

http://www.scielo.br/scielo.php?script=sci arttext\&pid=S0104-

$\underline{62762008000200006 \& l n g=p t \& n r m=i s o}$. Acesso em 22 janeiro de 2009

BORDENAVE, Juan E. Diaz. O que é comunicação. São Paulo: Brasiliense, 1982.

BORTOLIERO, Simone. "Mario Kaplún: a recepção como cidadania na América Latina". In: O pensamento latino-americano em comunicação, Revista Comunicação \& Sociedade n.25. São Bernardo: UMESP, 1996.

BOURDIEU, Pierre. Sobre a televisão. Rio de Janeiro: Jorge Zahar Editora, 1997.

BRASIL. Parâmetros curriculares nacionais: terceiro e quarto ciclos do ensino fundamental: introdução aos parâmetros curriculares nacionais. Brasília: Secretaria de Educação Fundamental - MEC/SEF, 1998.

BRASIL. Parâmetros curriculares nacionais de Língua Portuguesa. Brasília: Secretaria de Educação Fundamental - MEC/SEF, 1998.

CASSIRER, Ernst. Ensaio sobre o Homem: introdução a uma filosofia da cultura humana. São Paulo: Martins Fontes, 1994.

CHAUI, Marilena. Convite à Filosofia. São Paulo: Editora Ática, 1995.

CODELLO, Francesco. "Boa Educação": experiências libertárias e teorias anarquistas na Europa, de Godwin a Neill. São Paulo: Imaginário:Ícone, 2007.

COHN, Gabriel (org.). Comunicação e Indústria Cultural. São Paulo: T.A. Queiroz, 1978. 
D’AMBRÓSIO, Ubiratan. Educação Libertária. In Educação Libertária: Textos de um Seminário. Florianópolis: achimé Movimento - Centros de Cultura e Autoformação, 1996.

DUBOIS, Philippe. 0 ato fotográfico. Campinas. SP: Editora Papirus,2003.

DURAND, Gilbert. 0 imaginário: ensaio acerca das ciências e da filosofia da imagem. Rio de Janeiro: DIFEL, 2001.

DRUMMOND, Carlos. Reunião. 10 livros de Poesia de Carlos Drummond de Andrade. Rio de Janeiro: Livraria José Olympio Editora, 1971.

FERREIRA SANTOS, Marcos. Crepusculário:conferências sobre mitohermenêutica e educação em Euskadi. São Paulo: Zook, 2004 a.

FERREIRA SANTOS, Marcos.. "Educação de surdos e Corporeidade: do silêncio ao grito na gesticulação cultural”. In: Informativo Técnico Científico do INES. № 21, 2004b.

FERREIRA SANTOS, Marcos.. "A palavra habitada", originalmente publicada como "A Sacralidade do Texto em Culturas Orais". In: Diálogo. Revista de Ensino religioso, IX. agosto. № 35. p. 14-18, 2004c.

FERREIRA SANTOS, Marcos.. Humanitas: o cidadão educador e as relações de poder - possibilidades e limites da educação escolar. Revista Apase, São Paulo, v. IV, n. 04, 2005.

FOUCAULT, Michel. As palavras e as coisas. São Paulo: Martins Fontes, 1985.

FOUCAULT, Michel. Microfísica do Poder. Rio de Janeiro. Graal, $7^{a}$ ed., 1988.

FRANCO, Marília. (1996). "As linguagens audiovisuais no processo educativo". In: Comunicação e Plano decenal de Educação: Rumo ao ano 2003. São Paulo: Publicação dos Anais Faculdades Claretianas, 1996.

FREIRE, Paulo. Extensão ou Comunicação? Rio de Janeiro: Paz e Terra, 1992.

FREIRE, Paulo. Educação como prática da liberdade. Rio de Janeiro: Paz e Terra, 2000a. 
FREIRE, Paulo. Pedagogia da Esperança. São Paulo: Ed. Paz e Terra, 2000b.

FREIRE, Paulo. Pedagogia do Oprimido. Rio de Janeiro: Ed. Paz e Terra, 1970.

FREITAG, Armand Barrué. Max Stirner e o anarquismo individualista. São Paulo:

Editora Imaginário; São Paulo, Rio de Janeiro: UEL - Instituto de Estudos

Libertários; São Paulo: Nu-Sol. PUC, 2003

GALLO, Sílvio. "Pedagogia:princípios político-filosóficos". Educação Libertária. In

Educação Libertária: Textos de um Seminário. Florianópolis: achimé Movimento Centros de Cultura e Autoformação, 1996a.

GALLO, Sílvio. Pedagogia libertária. Anarquistas, Anarquismos e Educação. São Paulo: Editora Imaginário, 2007.

GODWIN, William. "Educação pela vontade". In WOODCOCK, G. Os grandes escritos anarquistas. Porto Alegre : L \& PM Editores, 1981.

GOLDMAN, Emma. O indivíduo, a sociedade e o estado e outros ensaios. São Paulo:Editora Hedra, 2007.

GOMES, Ana Luísa Zaniboni. Na boca do rádio: o radialista e as políticas públicas. São Paulo: Aderaldo \& Rotschild: OBORÉ, 2007.

HOUAISS. Dicionário HOUAISS da Língua Portuguesa. Disponível em http://houaiss.uol.com.br . Acesso em 25 de janeiro de 2009.

INTERVOZES. Boletim de novembro de 2007, p.2. Disponível em http://www.intervozes.org.br. Acesso em 27 de dezembro de 2008.

KAPLUN, Mário. Comunicación entre grupos: el método del Cassete-foro. CIID, Ottawa: 1984.

KAPLUN, Mário. La Educación para los Medios. Montevideo: Fundación de Cultura Universitaria de la Universidad de la Republica, 1987.

KAPLÚN, Gabriel. "Kaplún, intelectual orgânico: memoria afetiva". In: MARQUES DE MELO, José et al (orgs). Educomídia. Alavanca da cidadania: o legado utópico de Mario Kaplún. São Paulo: Cátedra UNESCO/UMESP, 2006. 
KAPLÚN, Gabriel. Mario Kaplún: El Viajero. Disponível em

http://www.lateja.org.uy/elpuente/epkaplun.htm 1998. Acessado em 10 de maio de 2008.

KAPLÚN, Mario. A la Educación por la Comunicación: la practica de la comunicación educativa. Santiago, Chile: UNESCO/OREALC, 1992.

KAPLÚN, Mario. Comunicación entre grupos: El método del cassette-foro. Buenos Aires: Editorial Humanitas, 1990.

KAPLÚN, Mario. El comunicador popular. Buenos Aires: Lumen-humanitas, 1996.

KAPLÚN, Mario. La comunicación de masas en América Latina. Bogotá: Ed. Educación Hoy, 1973.

KAPLÚN, Mario. Mis (primeros) cincuenta años de aprendiz de comunicador. Mini auto-biografía profesional. In: Boletín ALAIC No.7-8, São Paulo, 1992.

KAPLÚN, Mario. Producción de Programas de Radio: el guión - la realización. México, Editorial Cromocolor, 1994.

LOPES LIMA, Grácia. Educomunicação. Psicopedagogia e Prática radiofônica. Estudo de caso do Programa de rádio Cala-boca já morreu. ECA/USP. Dissertação de Mestrado, 2002.

LOPES LIMA, Grácia. Revista ENGRAMA. Publicação dos alunos da UNATI Universidade Aberta à terceira Idade da FITO/FEAO, Osasco, 2001-2004.

LOPES LIMA, Grácia e MELO, Teresa. Passo a passo para a conferência de meio ambiente nas escolas + Educomunicação: mudanças ambientais globais.

Brasília: Ministério da Educação, SECAD: Ministério do meio Ambiente, SAIC, 2008

LOPES LIMA, Grácia e MELO, Teresa. "Educomunicação e meio ambiente" In: Vamos cuidar do Brasil: conceitos e práticas em educação ambiental na escola. Secretaria de Educação continuada, Alfabetização e Diversidade (Secad) Ministério da Educação 2007. 
MATTELART, Armand e Michele. História das teorias da comunicação. São Paulo: Edições Loyola, 1999.

MATURANA, Humberto R e VARELA, Francisco J. A árvore do conhecimento: as bases biológicas da compreensão humana. São Paulo: Palas Athena, 2001.

MELO, José Marques et al (organizador). Educomídia, alavanca para a cidadania: o legado utópico de Mário Kaplún. São Bernardo do Campo: Cátedra UNESCO: Universidade Metodista de São Paulo, 2006.

MELO NETO, João Cabral. A educação pela pedra. Rio de Janeiro: Editora do Autor, 1966.

MELO, Teresa. A floresta, a mesa e as leis: espaços, comunicação e mudança cultural em comunidade tradicional da Estação Ecológica Juréia - Itatins. ECA/USP, Dissertação de Mestrado, 2000.

MULLER, Marcos José. PONTY-Merleau. Acerca da expressão. Porto Alegre: EDIPUCRS, 2001 (Coleção Filosofia 122).

OSTROWER, Faya. Criatividade e Processos de criação. Petrópolis: Vozes, 1987.

PERUZZO, Cicilia M. Krohling. Participação nas Rádios Comunitárias no Brasil, 1998. Disponível em http://www.bocc.ubi.pt/pag/peruzzo-cicilia-radio-comunitariabr.pdf. Acesso em 10 de novembro 2008.

PERUZZO, Cicilia M. Krohling. Comunicação comunitária e educação para a cidadania. PCLA - Volume 4 - número 1:outubro / novembro / dezembro 2002. Disponível em http://www2.metodista.br/unesco/PCLA/revista13/artigos\%20133.htm\#Comunicação\%20e\%20formação\%20para\%20a\%20cidadania . Acesso em 18 de janeiro de 2009.

PERUZZO, Cicilia M. Krohling. TV Comunitária no Brasil: aspectos históricos. Disponível em http://www.eca.usp.br/alaic/boletin8/cicilia.doc. Acesso em 18 de janeiro de 2009.

PICHON-RIVIÈRE, Enrique. O Processo Grupal. São Paulo: Martins Fontes, 1988. 
RAMONET, Ignácio. "Poder midiático". In: MORAES, Dênis de. Por uma outra comunicação. Mídia, mundialização cultural e poder. Rio de Janeiro: Record, 2003.

RICOEUR, Paul. A função hermenêutica do distanciamento. In Interpretação e ideologia. São Paulo: Editora Loyola, 1989.

RIVERA, Pablo Ramos. Para verte mejor... Para oirte mejor... La Habana: Editorial de Ciencias Sociales, 1996.

ROGERS, Carl R. Sobre o poder pessoal. São Paulo: Martins Fontes, 1989.

SAPERAS, E. Os Efeitos Cognitivos da Comunicação de Massas. Lisboa, Edições Asa, 2000.

SAVIANI, Demerval. As concepções pedagógicas na história da educação brasileira, disponível em

http://www.histedbr.fae.unicamp.br/navegando/artigos frames/artigo 036.html Acesso em 10 de dezembro 2008.

SOARES, Donizete. Educomunicação: o que é isso?, 2008. Disponível em http://www.portalgens.com.br/baixararquivos/textos/educomunicacao o que e isto. pdf. Acesso em 5 de outubro de 2008.

SOARES, Ismar de Oliveira. "Marco Teórico" in: Proposta de Educomunicação para a Família Salesiana. São Paulo: Editora Salesiana, 2001a.

SOARES, Ismar de Oliveira."Comunicação/Educação: a emergência de um novo campo e o perfil de seus profissionais." in Contato - Revista Brasileira de Comunicação, Arte e Educação no 2. Brasília: Senado Federal, Gabinete do Senador Artur da Távola, 1999, p. 19-74.

SOARES, Ismar de Oliveira. Alfabetização e Educomunicação. 0 papel dos meios de comunicação e informação na educação de jovens e adultos ao longo da vida. Disponível em www.usp.br/nce/wcp/arq/textos/89.pdf

SOARES, Ismar de Oliveira. Um novo campo de trabalho. Artigo publicado no Jornal da USP, seção Opinião. P 2, edição de 4 a 10 de junho de 2001. 
SOARES, Ismar de Oliveira. Educomunicação, caminho para a cidadania. 2002. Disponível em http://www.universia.com.br/materia/materia.jsp?id=3219. Acesso em 13 de dezembro 2008.

SODRÉ. Muniz. O monopólio da fala. Função e Linguagem da Televisão no Brasil. Petrópolis, RJ: Editora Vozes, 1981.

TOURAINE, Alain. Poderemos viver juntos? Iguais e diferentes. Petrópolis, RJ: Vozes, 1998.

THIOLLENT, Michel. Metodologia da Pesquisa-Ação. São Paulo: Cortez Autores Associados, 2000.

TRAGTENBERG, Maurício. Administração, poder e ideologia. São Paulo: Ed.Cortez, 1989.

WANDELLI, Raquel. Os donos dos meios de comunicação no Brasil ou A cartelização da mídia no Brasil. Artigo original do Jornal Eldorado, do curso de Jornalismo da Universidade do Sul de Santa Catarina, publicado pelo Centro de Estudos da Imprensa. Disponível em http://www.igutenberg.org/atualconcentra.html. Acesso em 23 de janeiro de 2009.

WOODCOCK, G. Os grandes escritos anarquistas. Porto Alegre: L \& PM, 1981. WOLF, M. Teorias das Comunicações de Massa. São Paulo, Martins Fontes, 2003.

\section{WEBGRAFIA:}

www.google.com

www.portalgens.com.br

www.cala-bocajamorreu.org

http://www.portalgens.com.br/video-escola/videosDOC2/../../videos/alta/05.wmv

http://www.dec.ufcg.edu.br/biografias/MGArtemi.html

http://cfh.ufsc.br/ simpozio/megaestetica/TratBelo/0764y005.htm

http://etimologias.dechile.net 